UNIVERSIDAD POLITÉCNICA DE MADRID

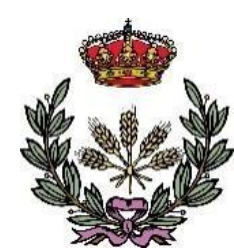

ESCUELA TÉCNICA SUPERIOR DE INGENIERÍA AGRONÓMICA,

ALIMENTARIA Y DE BIOSISTEMAS

DEPARTAMENTO DE PRODUCCIÓN AGRARIA

\title{
NUTRITIONAL STRATEGIES TO \\ IMPROVE CARCASS YIELD AND \\ CARCASS COMPOSITION IN \\ FATTENING RABBITS
}

PhD THESIS

Rubén Crespo Sancho

Agricultural Engineer

2020 

UNIVERSIDAD POLITÉCNICA DE MADRID

ESCUELA TÉCNICA SUPERIOR DE INGENIERÍA AGRONÓMICA,

ALIMENTARIA Y DE BIOSISTEMAS

DEPARTAMENTO DE PRODUCCIÓN AGRARIA

\section{NUTRITIONAL STRATEGIES TO IMPROVE CARCASS YIELD AND CARCASS \\ COMPOSITION IN FATTENING RABBITS}

\section{Rubén Crespo Sancho}

Agricultural Engineer

Supervised by

Dr. Nuria Nicodemus Martín

Escuela Técnica Superior de Ingeniería Agronómica, Alimentaria y de Biosistemas

Madrid, 2020 



\section{AGRADECIMIENTOS}

Me gustaría empezar agradeciendo al Poultry Research Center de Nutreco S.A. por darme la oportunidad, en primer lugar, de trabajar dos extraordinarios años con ellos y, en segundo lugar, permitirme realizar esta tesis doctoral. Agradecer también a todos los compañeros con los que compartí este tiempo, con muchos de los cuales ha quedado una buena amistad. Mencionar especialmente a Clara, Erika, Endika, Cristina, Ana, Jano, Álvaro y Ángel que han estado muy presentes en este trabajo y lo han hecho posible.

Mi más profundo agradecimiento a mis padres, Carlos y Ana, por creer en mí y darme su apoyo incondicional. Y a Mildred por su motivación continúa y hacerme cada vez mejor persona, además de ser una gran inspiración y referencia para mí.

Agradecer a todos mis amigos y personas cercanas, así como a todos aquellos con los que he compartido esta parte tan importante de mi vida.

Y, por último, expresar mi total gratitud a mi tutora Nuria Nicodemus. Sin ella este trabajo no habría podido realizarse. Agradecerte tu paciencia, que sé que ha sido muy grande en muchas ocasiones, y tu gran apoyo. 



\section{INDEX OF CONTENTS}





\section{INDEX OF CONTENT}

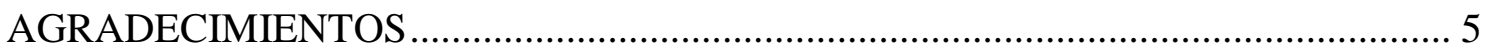

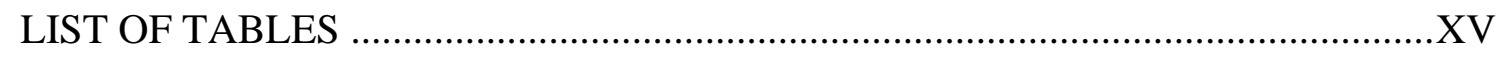

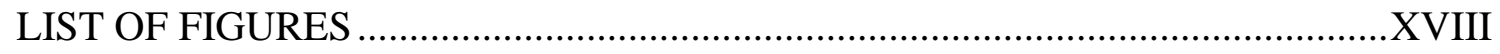

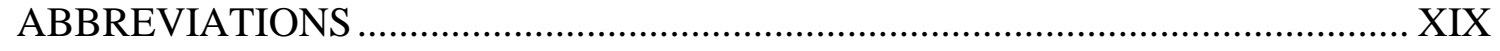

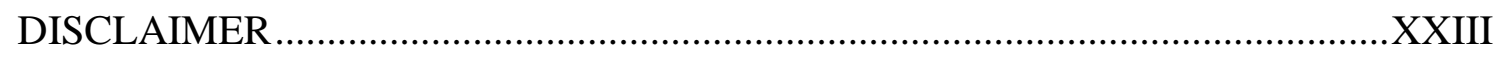

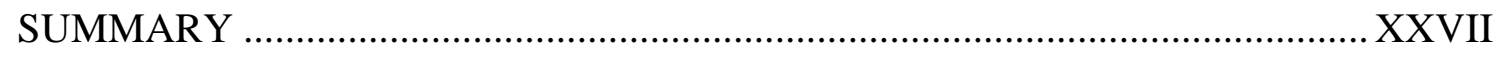

RESUMEN ..................................................................................... XXXVII

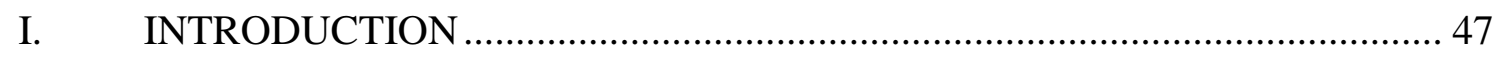

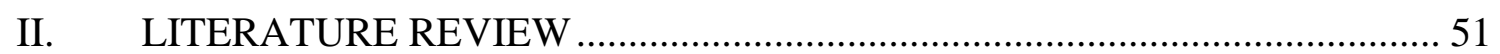

2.1. Carcass quality for the different links of the food chain .............................. 51

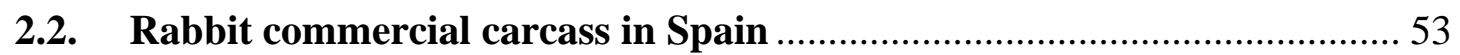

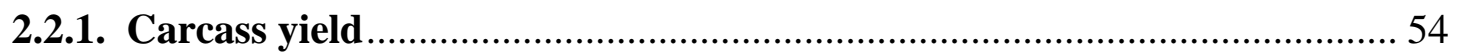

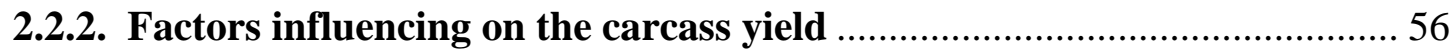

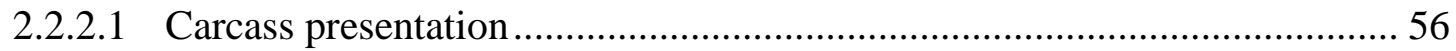

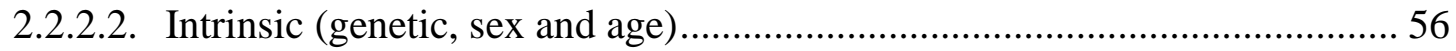

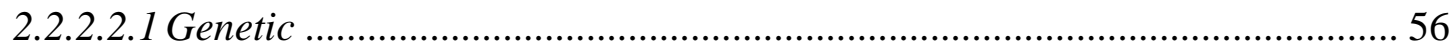

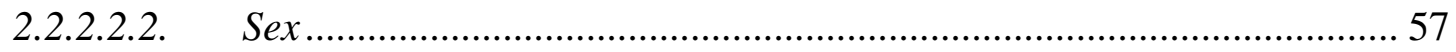

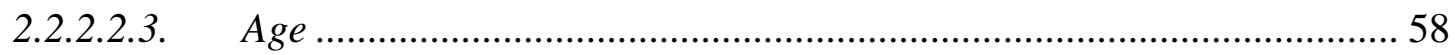

2.2.2.3. Extrinsic (management, environment, feeding) ….................................. 58

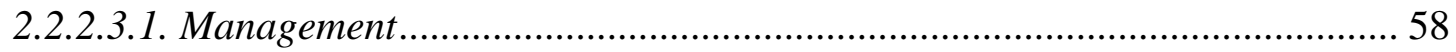

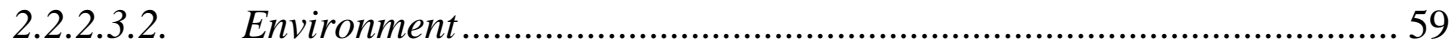

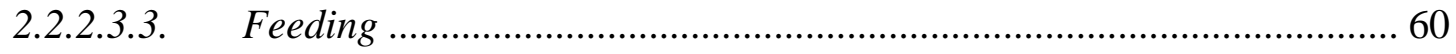


2.3. Chemical composition of the rabbit meat

2.3.1. Factors that influence the chemical composition ............................... 72

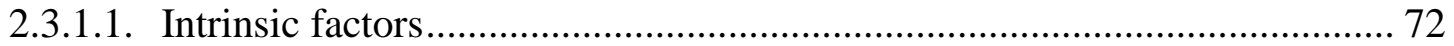

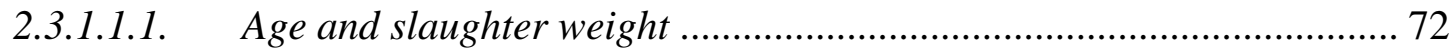

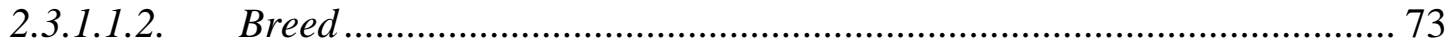

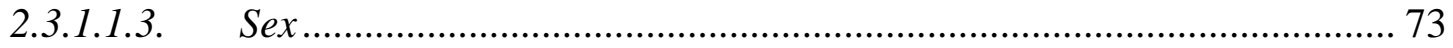

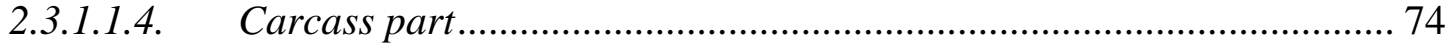

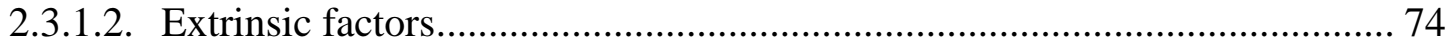

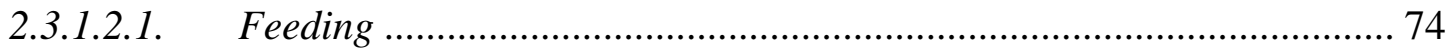

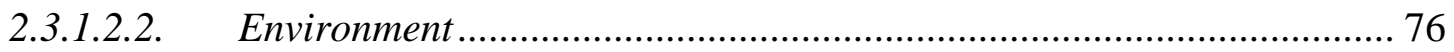

2.4. Measurement of chemical composition ................................................... 76

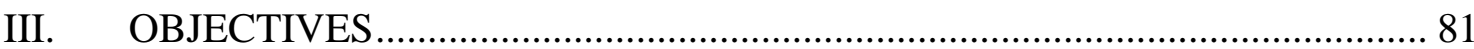

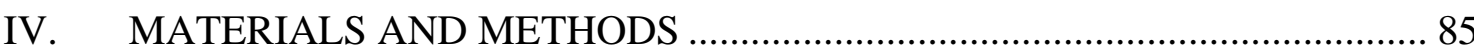

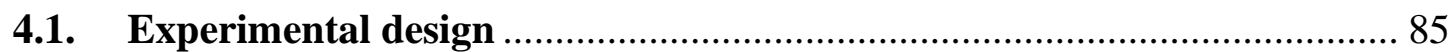

4.1.1. Experiment 1: Effect of an enzyme complex on the productive performance, slaughter traits and nitrogen and energy balance in growing rabbits.

4.1.2. Experiment 2: Effect of an enzyme complex in a protein and energy reduced diet on productive performance, slaughter traits and nitrogen and energy balance in growing rabbits.

4.1.3. Experiment 3: Effect of different lignin levels and sources on productive performance, slaughter traits and nitrogen and energy balance in growing rabbits. 
4.1.4. Experiment 4: Effect of feed restriction on growth performance, carcass yield and nitrogen and energy balance in growing rabbits.

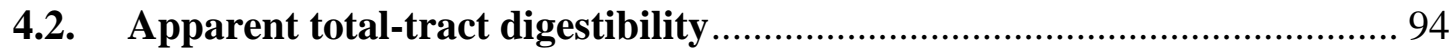

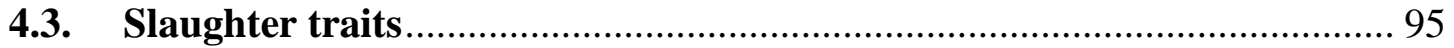

4.4. Carcass chemical composition and nitrogen and energy balances............ 96

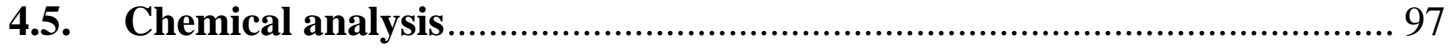

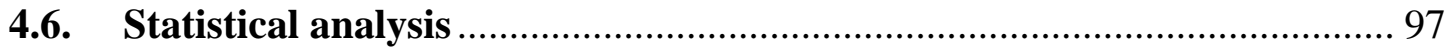

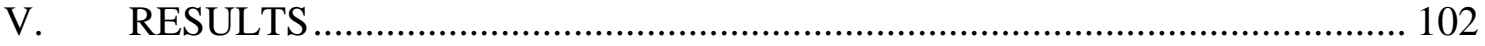

5.1. Experiment 1: Effect of an enzyme complex on the productive performance, slaughter traits and nitrogen and energy balance in growing rabbits.............. 102

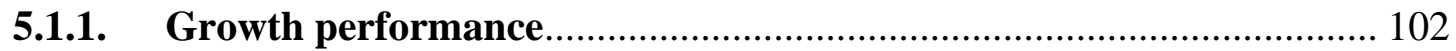

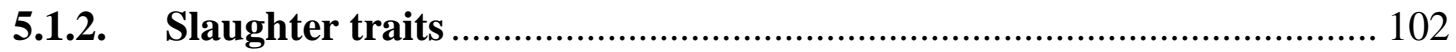

5.1.3. Apparent total-tract digestibility (ATTD) ....................................... 102

5.1.4. Carcass chemical composition and nitrogen and energy balances...... 103

5.2. Experiment 2: Effect of an enzyme complex in a protein and energy reduced diet on productive performance, slaughter traits and nitrogen and energy balance in growing rabbits. 108

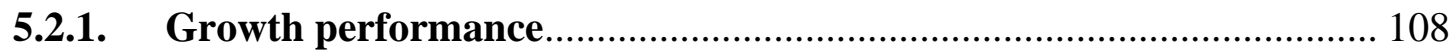

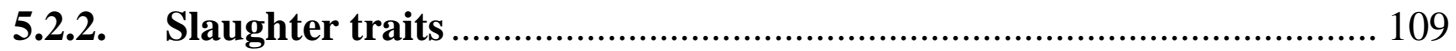

5.2.3. Apparent total-tract digestibility (ATTD) .......................................... 109

5.2.4. Carcass chemical composition and nitrogen and energy balances ...... 113 
5.3. Experiment 3: Effect of different lignin levels and sources on productive performance, slaughter traits, and nitrogen and energy balance in growing rabbits.

5.3.1. Growth performance 118

5.3.2. Slaughter traits

5.3.3. Apparent total-tract digestibility (ATTD)

5.3.4. Carcass chemical composition and nitrogen and energy balances 124

5.4. Experiment 4: Effect of feed restriction on growth performance, carcass yield and nitrogen and energy balance in growing rabbits. 128

5.4.1. Growth performance 128

5.4.2. Slaughter traits 129

5.4.3. Apparent total-tract digestibility (ATTD) 130

5.4.4. Carcass chemical composition and nitrogen and energy balances 135

VI. GENERAL DISCUSSION 141

6.1. Effect of enzyme supplementation (Experiments 1 and 2) 141

6.1.1. Growth performance and slaughter traits (Experiments 1 and 2) ...... 141

6.1.2. Apparent total-tract digestibility (ATTD) (Experiments 1 and 2) ...... 144

6.1.3. Carcass chemical composition and nitrogen and energy balances (Experiments 1 and 2) 146

6.2. Effect of lignin source and level (Experiment 3) 148

6.2.1. Growth performance and slaughter traits (Experiment 3) 148

6.2.2. Apparent total-tract digestibility (ATTD) (Experiment 3) 151 
6.2.3. Carcass chemical composition and nitrogen and energy balances. (Experiment 3)

6.3. Effect of feed restriction (Experiment 4).

6.3.1. Growth performance and slaughter traits (Experiment 4) 154

6.3.2. Apparent total-tract digestibility (ATTD) (Experiment 4) 157

6.3.3. Carcass chemical composition and nitrogen and energy balances (Experiment 4). 158

6.4. Effect of slaughter weight on carcass yield 159

VII. GENERAL CONCLUSIONS AND IMPLICATIONS 164

7.1. Conclusions 164

7.2. Implications 166

VIII. REFERENCES 170 


\section{LIST OF TABLES}

Table 1. Average carcass weights demanded in Spain, France, and Italy.... .53

Table 2. Enzymatic activity of the compound used (according to the producer). 86

Table 3. Ingredients and analysed chemical composition of the experimental feed (Experiment 1)

Table 4. Ingredients and analysed chemical composition of the experimental feeds (Experiment 2)

Table 5. Chemical composition of the defatted grape seed meal, comparison of different analyses (Experiment 3) .91

Table 6. Chemical composition of Arbocel® (\%), comparison of different analysis (Experiment 3) 91

Table 7. Ingredients and analysed chemical composition of the experimental feeds (Experiment 3) .92

Table 8. Ingredients and analysed chemical composition of the experimental feed (Experiment 4) .94

Table 9. Effect of enzyme dose supplementation (100, 200, 400 and $800 \mathrm{ppm}$ ) on

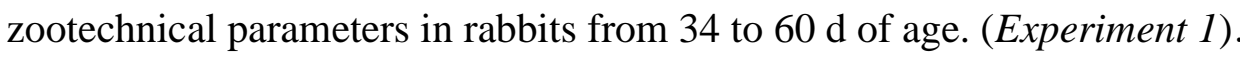
104

Table 10. Effect of enzyme dose supplementation (100, 200, 400 and 800 ppm) on slaughter traits at $62 \mathrm{~d}$. (Experiment 1)....... 105

Table 11. Effect of enzyme dose supplementation (100, 200, 400 and $800 \mathrm{ppm})$ on apparent total-tract digestibility (ATTD) from 53 to $57 \mathrm{~d}$ of age. (Experiment 1)...... 105 Table 12. Effect of enzyme dose supplementation (100, 200, 400 and $800 \mathrm{ppm})$ on carcass chemical composition at 34 and $60 \mathrm{~d}$ of age. 106

Table 13. Effect of enzyme dose supplementation (100, 200, 400 and $800 \mathrm{ppm})$ on nitrogen and energy balance from 34 to $60 \mathrm{~d}$. (Exp. 1). 107 
Table 14. Effect of enzyme dose supplementation (0, 100, $200 \mathrm{ppm})$ and type of diet on zootechnical parameters in rabbits from 34 to $60 \mathrm{~d}$ of age. (Experiment 2)..... 110

Table 15. Effect of enzyme dose supplementation (0, 100, $200 \mathrm{ppm})$ and type of diet on slaughter traits at $62 \mathrm{~d}$. (Experiment 2)

Table 16. Effect of enzyme dose supplementation (0, $200 \mathrm{ppm})$ and type of diet on apparent total-tract digestibility (ATTD) from 53 to $57 \mathrm{~d}$. (Experiment 2) 112

Table 17. Effect of enzyme dose supplementation $(0,100,200 \mathrm{ppm})$ and type of diet on carcass chemical composition at 34 and $60 \mathrm{~d}$. (Experiment 2)...

Table 18. Effect of enzyme dose supplementation (0, $200 \mathrm{ppm})$ and type of diet on nitrogen balance from 34 to $60 \mathrm{~d}$. (Experiment 2) 116

Table 19. Effect of enzyme dose supplementation $(0,200 \mathrm{ppm})$ and type of diet on energy balance from 34 to $60 \mathrm{~d}$. (Experiment 2).

Table 20. Effect of lignin source and level on zootechnical parameters in rabbits from 34 to $60 \mathrm{~d}$ of age, breed in individual cages. (Experiment 3)

Table 21. Effect of lignin source and level on zootechnical parameters in rabbits from 35 to $61 \mathrm{~d}$ of age, breed in collective cages. (Experiment 3 )

Table 22. Effect of lignin source and level on slaughter traits at $62 \mathrm{~d}$. (Experiment 3)

Table 23. Effect of lignin source and level on apparent total-tract digestibility (ATTD) from 53 to 57 d. (Experiment 3)

Table 24. Effect of lignin source and level on carcass chemical composition at 34 and 60 d. (Experiment 3) 125

Table 25. Effect of lignin source and level on nitrogen and balance from 34 to $60 \mathrm{~d}$. (Experiment 3) 126 
Table 26. Effect of lignin source and level on energy balance from 34 to $60 \mathrm{~d}$. (Experiment 3)

Table 27. Effect of the feeding restriction strategies on zootechnical parameters in rabbits from 34 to $61 \mathrm{~d}$ of age. (Experiment 4$)$.

Table 28. Effect of the feeding restriction strategies on slaughter traits at $61 \mathrm{~d}$. (Experiment 4) 132

Table 29. Effect of the feeding restriction strategies on apparent total-tract digestibility (ATTD) from 53 to 57 d. (Experiment 4)

Table 30. Effect of the feeding restriction strategies on carcass chemical composition at 34 and 61 d. (Experiment 4) 134

Table 31. Effect of the feeding restriction strategies on nitrogen and energy balance from 34 to 61 d. (Experiment 4$)$ .137 


\section{LIST OF FIGURES}

Figure 1. Commercial cutting of a $2.3 \mathrm{~kg}$ live weight rabbit (Ouhayoun, 1991a)...... 56

Figure 2. Effect of the neutro detergent fibre (NDF) on the weight of the cecum content (CCW; \%LW) (De Blas et al., 1999). .65

Figure 3. Effect of acid detergent fibre (ADL) level on the average retention time of the digesta (ART) in caecum and on the cecum content weight (CCW) (García et al., 2002b).

Figure 4. Effect of slaughter live weight on carcass yield. 161 


\section{ABBREVIATIONS}

Abbreviation /

\section{Abreviatura}

A

ADF

ADFI

ADG

ADL

AIC

AJDU

AL

ATTD

B

BIA

BIC

BGU

BW

BWS

$\mathrm{CP}$

$\mathrm{CCW}$

$\mathrm{CMC}$

d

D2O

DE

DEi

DM

DN

DNi

DoP

DP

DWG
ENGLISH

Arbocel ${ }^{\circledR}$

Acid detergent fibre

Average daily feed intake

Average daily gain

Acid detergent lignin

Akaike information criterion

Apple juice depectinising Activity

Ad libitum

Apparent total tract digestibility

Basal

Bioelectrical impedance technique

Bayesian information criterion

B-glucanase Unit

Body weight

Body weight before slaughter

Crude protein

Cold carcass weight

Carboxymethyl cellulose

Day / days

Deuterium oxide

Digestible energy

Digestible energy intake

Dry matter

Digestible nitrogen

Digestible nitrogen intake

Dressing out percentage

Digestible protein

Daily weight gain

\section{ESPAÑNOL}

\section{Arbocel ${ }^{\circledR}$}

Fibra ácido detergente

Consumo medio diario

Ganancia media diaria

Lignina ácido detergente

Criterio de información de Akaike

Actividad pectinasa en zumo de

manzana

Ad libitum

Digestibilidad total aparente

Basal

Técnica de impedancia bioeléctrica

Criterio de información bayesiano

Unidad $\beta$-glucanasa

Peso vivo

Peso vivo al sacrificio

Proteína bruta

Peso canal fría

Carboximetilcelulosa

Día / días

Óxido de deuterio

Energía digestible

Consumo de energía digestible

Materia seca

Nitrógeno digestible

Consumo de nitrógeno digestible

Rendimiento a la canal

Proteína digestible

Ganancia media diaria 


\begin{tabular}{|c|c|c|}
\hline $\begin{array}{l}\text { Abbreviation / } \\
\text { Abreviatura }\end{array}$ & ENGLISH & ESPAÑOL \\
\hline $\mathrm{EE}$ & Ether extract & Extracto etéreo \\
\hline ELW & Empty live weight & Peso vivo vacío \\
\hline ER & Energy retained & Energía retenida \\
\hline ERE & Epizootic rabbit enteropathy & Enteropatía epizoótica del conejo \\
\hline Exp. & Experiment & Experimento \\
\hline FAU & Fungal alpha-amylase unit & Unidad alfa-amilasa fúngica \\
\hline FCR & Feed conversion ratio & Índice de conversión \\
\hline FI & Feed intake & Consumo de pienso \\
\hline $\mathrm{G}$ & Defatted grape seed meal & Granilla de uva \\
\hline GE & Gross energy & Energía bruta \\
\hline GEi & Gross energy intake & Consumo de energía bruta \\
\hline GLM & General linear model & Modelo lineal general \\
\hline $\mathrm{HCW}$ & Hot carcass weight & Peso canal caliente \\
\hline HUT & Haemoglobin unit tyrosine base & $\begin{array}{l}\text { Unidades de hemoglobina en base } \\
\text { de tirosina }\end{array}$ \\
\hline $\mathrm{kg}$ & Kilogram & Kilogramo \\
\hline $\mathrm{kHz}$ & Kilohertz & Kilohercios \\
\hline $\mathrm{kJ}$ & Kilo Joules & Kilojulios \\
\hline LW & Live weight & Peso vivo \\
\hline MJ & Mega Joules & Megajulios \\
\hline MRI & Magnetic resonance imaging & Imagen por resonancia magnética \\
\hline $\mathrm{N}$ & Nitrogen & Nitrógeno \\
\hline $\mathrm{Ni}$ & Nitrogen intake & Consumo de nitrógeno \\
\hline $\mathrm{NDF}$ & Neutral detergent fibre & Fibra neutro detergente \\
\hline NIRS & Near-infrared spectroscopy & $\begin{array}{l}\text { Espectroscopía del infrarrojo } \\
\text { cercano }\end{array}$ \\
\hline NR & Nitrogen retained & Nitrógeno retenido \\
\hline $\mathrm{OM}$ & Organic matter & Materia orgánica \\
\hline$P$ & Probability & Probabilidad \\
\hline ppm & Parts per million & Partes por millón \\
\hline
\end{tabular}


Abbreviation /

Abreviatura

PRC

$\mathrm{R} \& \mathrm{D}$

SD

SEM

SLW

TOBEC

UPV

VFA

$\mathrm{XU}$

\section{ENGLISH}

Poultry Research Centre

Research \& Development

Standard deviation

Standard error of the mean

Slaughter live weight

Total Body Electrical

Conductivity

Polytechnical University of

Valencia

Volatile Fatty acids

Xylanase unit

\section{ESPAÑOL}

Centro de investigación de avicultura

Investigación y desarrollo

Desviación estándar

Error estándar de la media

Peso vivo al sacrificio

Conductividad eléctrica total

Universidad Politécnica de

Valencia

Ácidos grasos volátiles

Unidad xilanasa 


\section{DISCLAIMER}

Some results of this $\mathrm{PhD}$ Thesis are already published:

- $\quad$ Experiment 4: Crespo, R., Alfonso, C., Saiz del Barrio, A., García Ruiz, A.I., Marco, M. and Nicodemus, N. (2020). Effect of feed restriction on performance, carcass yield and nitrogen and energy balance in growing rabbits. Livest. Sci., 241: 104278. 
SUMMARY 


\section{SUMMARY}

The main objective of this $\mathrm{PhD}$ was to study the effect of different nutritional strategies on carcass traits. Secondary, it was also researched the effect of those strategies on growth performance, carcass chemical composition and nitrogen and energy balance in growing rabbits. For this purpose, four experiments were conducted. In experiment 1 was studied the effect of supplementation of a multi-enzyme complex at different doses on a standard diet on performance parameters, carcass traits, nutrient digestibility and nitrogen and energy balance in growing rabbits. In the experiment 2, same multi-enzyme complex than in experiment 1 was used, but two different diets were formulated, with different DP, DE and NDF content. Experiment 3 studied the effect of three levels and two sources of lignin. And, in the last one, experiment 4, feeding restriction on growth performance, carcass traits, nutrient digestibility and nitrogen and energy balance in growing rabbits was studied. All the feeds supplied to the rabbits were non-medicated.

In experiment 1 , the purpose was to compare the inclusion of a fungal multi-enzyme complex (activity of $100 \mathrm{XU} / \mathrm{g}$ pentosanase, $40 \mathrm{CMC} / \mathrm{g}$ cellulase, $30 \mathrm{FAU} / \mathrm{g}$ amylase, 100 XU/g xylanase, $700 \mathrm{HUT} / \mathrm{g}$ protease, $4000 \mathrm{AJDU} / \mathrm{g}$ pectinase and $200 \mathrm{BGU} / \mathrm{g} \beta$ glucanase) in the feed at different doses $(0,100,200,400$ and $800 \mathrm{ppm})$, on productive parameters, carcass traits and nitrogen and energy balance in growing rabbits. A total of 225 rabbits, weaned at $34 \mathrm{~d}$ of age, were used. They were housed in individual cages and randomly assigned to five treatments. A basal feed was formulated (CP: 17.6\%; starch: 17.4\%, NDF: 35.9\%, DE: $2797 \mathrm{kcal} / \mathrm{DM} \mathrm{kg}$ ) and supplemented with different doses of the enzyme complex. Feed intake and animal weight (from 34 to $48 \mathrm{~d}$ of age and from 49 to $60 \mathrm{~d}$ ) were controlled. In 11 rabbits per treatment, body composition was estimated by Bioelectrical Impedance technique (BIA) at 34 and $60 \mathrm{~d}$ of age to estimate the nitrogen balance. At the end of the trial, 24 rabbits per treatment were slaughtered and the carcass, 
the entire digestive tract, the full and empty stomach, and the full caecum were weighted. Between days 53 and 57 of life, a digestibility trial was done (for DM, OM, CP, EE, NDF, GE; $n=11$, except for the 100-ppm dose. During the first period (34-48 d) enzyme supplementation linearly improved the feed conversion ratio $(\mathrm{FCR})(\mathrm{P}<0.05)$, without affecting feed intake (DFI) or growth (DWG). In the second period (49-60 d), both FCR and DWG varied quadratically $(\mathrm{P}<0.05)$ with enzyme supplementation, being the optimum level for both: $400 \mathrm{ppm} / \mathrm{kg}$. The digestibility of DM, OM, EE and GE decreased linearly $(\mathrm{P}<0.05)$ and the weight of the digestive tract $(\% \mathrm{BW})$ increased linearly $(\mathrm{P}<0.05)$ with the increase of enzyme complex dose, without affecting the carcass yield, which was $57.8 \%$, on average. Enzymes had no effect on nitrogen and energy balance, except on energy losses in faeces $(\mathrm{P}<0.05)$ which increased with the dose due to the worse GE digestibility. Carcass composition was neither affected $(\mathrm{P}>0.05)$ by the level of the enzyme complex supplementation.

In experiment 2, the objective was to compare the effect of supplementation with the same multi-enzyme complex in two feeds with different levels of digestible energy (DE), digestible protein (DP) and NDF on growth performance, carcass characteristics and nitrogen and energy balance in growing rabbits. Three doses (0, 100 and $200 \mathrm{ppm})$ of the same enzyme complex were added to two different basal diets (Diet A: CP: 17.6\% DM; starch: 17.4\% DM; NDF 35.9\% DM, DE: $2797 \mathrm{kcal} / \mathrm{kg}$ DM and Diet B: CP: 15.8\% DM, starch: 17.5\% DM, NDF: 37.4\% DM, DE: $2585 \mathrm{kcal} / \mathrm{kg} \mathrm{DM).} \mathrm{Therefore,} \mathrm{a} \mathrm{total} \mathrm{of}$ 270 rabbits were weaned at $34 \mathrm{~d}$ and housed in individual cages. The parameters measured were the same as in the previous experiment. The digestibility trial (between days 53 and 57 of age) was performed on both diets (A and B) but only to the 0 and 200 ppm doses. The addition of enzymes did not affect the digestibility, or any other productive parameters studied in the growing period. Diet B decreased $(\mathrm{P}<0.01)$ the digestibility of 
DM, OM, NDF and GE vs. diet A (5.98, 5.66, 4.91 and 22.59\%, respectively). Digestible nitrogen (DNi) and DE intake were lower for diet B than diet A (10\% and 7\% respectively, $\mathrm{P}<0.01)$. The lower $\mathrm{DN}$ intake of animals fed with diet $\mathrm{B}$ led to a lower DN in carcass $(4 \% ; \mathrm{P}<0.05)$ and a reduction of the nitrogen excreted in urine $(19.4 \% ; \mathrm{P}<0.05)$ and in faeces $(6.3 \%$; $\mathrm{P}<0.05)$. Digestible energy intake of diet $\mathrm{B}$ was lower $(\mathrm{P}<0.05)$ compared with diet A (0.998 vs. $0.947 \mathrm{MJ} / \mathrm{kg} \mathrm{BW}^{0.75}$.d. Accordingly, animals of diet B had lower energy retention efficacy, both in whole body $\left(0.389 v s .0 .360 \mathrm{~kJ} / \mathrm{kg} \mathrm{BW}^{0.75} . \mathrm{d}\right)$ and in carcass $\left(0.231\right.$ vs. $\left.0.211 \mathrm{~kJ} / \mathrm{kg} \mathrm{BW}^{0.75} \mathrm{~d}\right)$. Due to the lower energy ingestion and efficacy, energy excreted in faeces was higher $\left(0.660\right.$ vs. $\left.0.705 \mathrm{MJ} / \mathrm{kg} \mathrm{BW}^{0.75} . \mathrm{d} ; \mathrm{P}<0.05\right)$ in animals of diet B, whereas energy excreted in skin and viscera was higher in diet A (0.157 vs. $0.148 \mathrm{MJ} / \mathrm{kg} \mathrm{BW}^{0.75}$.d). The lower retention of $\mathrm{N}$ and energy of diet $\mathrm{B}$, resulted in a lower weight at $48 \mathrm{~d}$ of age (1650 g vs. $1622 \mathrm{~g}, \mathrm{P}<0.05)$, due to a lower DWG in the first period (58.2 vs. 60.2; $\mathrm{P}<0.05)$, although second fattening period and final weight did not differ significantly. Feed intake during the whole growing period was $2.92 \%$ higher for diet $\mathrm{B}$, so FCR increased $(2.52$ vs. 2.63, $\mathrm{P}<0.05)$. The type of diet did not affect carcass yield, although the rabbits of diet B had heavier digestive tract and full and empty stomach $(\mathrm{P}<0.05)$. Carcass chemical composition of animals fed diet A showed a higher EE and energy content $(\mathrm{P}<0.05)$, whereas diet $\mathrm{B}$ had higher water, $\mathrm{CP}$, and ash content $(\mathrm{P}<0.05)$.

In the third trial, the aim was to study the effect of including different levels of acid detergent lignin (ADL) (Low (L): 5\% DM, Medium (M): 6\% DM and High (H): 7\% DM) and different sources of lignin (Arbocel® (A) vs. defatted grape seed meal (G)) on performance, carcass characteristics and nitrogen and energy balance in growing rabbits. A total of 936 rabbits were used, 216 were weaned at $34 \mathrm{~d}$ of age and housed in individual cages, and the remaining 720 were weaned at $35 \mathrm{~d}$ of age and housed in collective cages (5 rabbits/cage). Five different feeds were formulated: one control diet for both sources 
(AL and GL: DE: 2939 kcal/kg DM, CP: 18.4\% DM, NDF: 36.4\% DM; ADF: $21.3 \%$ DM; ADL: 4.78\% DM; Starch: 15.5\% DM), two diets with an average level for each source (AM (DE: $2825 \mathrm{kcal} / \mathrm{kg}$ DM, CP: 17.7\% DM , NDF: 37.8\% DM; ADF: $23.8 \%$ DM; ADL: 5.87\% DM; Starch: 15.1\% DM) and GM (DE: 2909 kcal/kg DM, CP: 17.9\% DM , NDF: 36.2\% DM; ADF: 21.8\% DM; ADL: 6.03\% DM; Starch: 15.6\% DM) ) and other two diets with a high level for each source AH (DE: $2848 \mathrm{kcal} / \mathrm{kg}$ DM; CP: $18.1 \%$ DM, NDF: 37.7\% DM; ADF: 23.8\% DM; ADL: 6.23\% DM; Starch: 14.5\% DM) and GH (ED: $2908 \mathrm{kcal} / \mathrm{kg}$ DM, CP: 17.6\% DM, NDF: 35.4\% DM; ADF: 22.0\% DM; ADL: 6.72\% DM; Starch: $15.9 \%$ DM)). In rabbits housed in collective cages, weight and intake were measured at the beginning and at the end of the growing period ( 35 and $61 \mathrm{~d}$ of age), feed conversion ratio (FCR) was calculated for that period, and mortality was recorded daily. For rabbits housed in individual cages average daily intake and weight were controlled in two periods from 34-48 d, and 49-60 d of life, as well as the FCR and daily mortality during growing period. In 11 rabbits per treatment, body composition was estimated by Bioelectrical Impedance technique at 34 and $60 \mathrm{~d}$ of age to estimate the nitrogen and energy balance. At the end of the trial, 24 rabbits per treatment were slaughtered and the carcass weight, the entire digestive tract, the full and the empty stomach and full caecum were measured. Between days 53 and 57 of life a digestibility trial was done (DM, OM, CP, EE, NDF and GE, n=11). For rabbits in collective cages, the highest level of lignin affected the FCR compared with the other two levels (2.65 on average $v s .2 .69 \mathrm{~g} / \mathrm{g}, \mathrm{P}<0.05)$ without affecting daily feed intake $(139 \mathrm{~g} / \mathrm{d})$ or growth $(52.2$ $\mathrm{g} / \mathrm{d})$. The digestive tract weight (\%BW) decreased with medium and high levels of lignin, compared with the control one (17.4 on average $v s .17 .9 \% ; \mathrm{P}=0.05)$ but carcass yield was not affected (58.2\% on average). The apparent feed digestibility of DM, OM and GE was higher with the lowest level of ADL compared to the average of the other two: DM (58.3 
vs. 56.8\%), OM (60.2 vs. 58.8\%), and GE (60.2 vs. 58.9\%). Apparent digestibility of CP for the medium level was lower than the low level $(70.1$ vs. $72.6 \%, \mathrm{P}=0.05)$ while the diet with the highest level of ADL showed an intermediate value (71.0\%). EE digestibility increased with level inclusion of $\operatorname{ADL}(84.7,85.8$, and 88.0\%, respectively). The animals fed high levels of ADL consumed less DN than low and medium levels (1.901 vs. 1.992 $\mathrm{g} \mathrm{NDi} / \mathrm{kg} \mathrm{BW} \mathrm{B}^{0.75} . \mathrm{d}$, on average, $\left.\mathrm{P}<0.05\right)$, and tended to improve the retention efficiency (0.348 vs. $0.338 \%$, on average, $\mathrm{P}=0.07)$, so the $\mathrm{N}$ retained in all lignin levels was similar (0.669 $\mathrm{g} \mathrm{NR}$ carcass $\left./ \mathrm{kg} \mathrm{BW}^{0.75} \cdot \mathrm{d}\right)$. $\mathrm{N}$ excretion in urine was lower for $\mathrm{M}$ and $\mathrm{H}$ lignin levels (average of 0.894 vs. $1.003 \mathrm{~g} \mathrm{~N} / \mathrm{kg} \mathrm{BW}^{0.75}$.d). Otherwise the energy losses in faeces increased in these two diets $(+5 \%)$ compared with the low level of ADL. Arbocel ${ }^{\circledR}$ increased FCR during the growing period in individual cages $(2.56$ vs. $2.52 \mathrm{~g} / \mathrm{g}, \mathrm{P}<0.05)$, as well as in group cages $(+1.42 \%, \mathrm{P}<0.05)$. The Arbocel ${ }^{\circledR} \mathrm{OM}$ digestibility was worse than defatted grape seed meal $(56.9$ vs. $57.7 \%, \mathrm{P}<0.05)$. The carcass chemical composition of the animals was not affected neither by the source nor by the level of feed ADL.

The aim of the experiment 4 was to study the effect of different feeding restriction strategies in growing rabbits. A total of 600 rabbits were weaned at $34 \mathrm{~d}$, caged in groups (5 animals/cage; 24 cages/treatment) and randomly assigned to the 5 treatments. Control group (AL) was fed ad libitum and the others four were restricted 80 and $70 \%$ of theoretical ad libitum intake (R80 and R70, respectively), during the whole fattening period or until $48 \mathrm{~d}$ (R80AL and R70AL, respectively). Only one diet was formulated (CP: $159 \mathrm{~g} / \mathrm{kg}$ DM; NDF: $324 \mathrm{~g} / \mathrm{kg}$ DM; DE: $2689 \mathrm{kcal} / \mathrm{kg} \mathrm{DM})$. At the end of the fattening period, 24 rabbits per treatment were slaughtered and the weight of carcasses and digestive organs were measured. A digestibility trial was done in individual metabolic cages between 53 and $57 \mathrm{~d}(12$ rabbits/treatment $)$. Feed restriction impaired $(\mathrm{P}<0.001)$ 
the feed conversion ratio (1.93 vs. $1.82 \mathrm{~g} / \mathrm{g}$, on average) and daily weight gain (42.4 vs. $60.3 \mathrm{~g}$, on average) from 34 to $48 \mathrm{~d}$. However, from 48 to $61 \mathrm{~d}$ there was a compensatory growth in rabbits fed ad libitum (R80AL and R70AL) once they finished the restriction period (61.1 vs. $46.4 \mathrm{~g} / \mathrm{d}$, on average). On the whole fattening period, the compensatory growth led to a better feed conversion ratio (2.25 vs. $2.33 \mathrm{~g} / \mathrm{g} ; \mathrm{P}<0.001)$, and rabbits fed R80AL finished the fattening period with a similar final body weight than those fed the control diet. Internal organs increased $(\mathrm{P}<0.05)$ their size, when rabbits were fed $a d$ libitum after the restriction period, especially in those restricted at $70 \%$ in the first phase. Average mortality was $12.8 \%$ and it was not affected by treatments. Protein digestibility in treatments R80 and R70 tended to be higher than those restricted until $48 \mathrm{~d}$. The digestibility of the other constituents was not affected by any of the restriction strategies. The nitrogen and ashes concentration in carcass increased, whereas fat and energy content decreased in whole fattening period of restricted groups $(\mathrm{P}<0.001)$. Efficacy of nitrogen retention tended to increase $(\mathrm{P}=0.074)$ and the nitrogen and energy excretion through the faeces, and urine+heat losses decreased $(\mathrm{P}<0.001)$ in restricted animals.

From the results of these 4 experiments, it can be concluded that in growing rabbits the supplementation with this multi-enzyme complex did not improve digestibility, nitrogen balance or reduce the weight of the digestive tract, and had no effect on the carcass yield. The use of enzymes improved the feed conversion ratio in the first period, so its use would be interesting in animals after weaning. Under the conditions of this study, the addition of enzymes in a lower nutritional value feed, neither improved the feed efficiency, the $\mathrm{N}$ balance, nor the carcass yield. Including ADL levels above 5\% in isoenergetic diets decreased gastrointestinal weight, although this effect was not reflected in carcass yield. Arbocel ${ }^{\circledR}$ got worse FCR without affecting the growth. Restriction until 
$48 \mathrm{~d}$ could be a useful tool to reduce the environmental impact of the farms without an impairment of growth performance and carcass yield in the whole fattening period.

In non-enteropathy conditions, none of the strategies studied had an effect on mortality. 


\section{RESUMEN}




\section{RESUMEN}

La presente Tesis Doctoral se compone de cuatro experimentos cuyo objetivo es el estudio de los efectos de diferentes estrategias nutricionales sobre, principalmente, el rendimiento y las características de la canal. Y, secundariamente, estudiar cómo afectan dichas estrategias a la composición química de las canales y, al balance nitrogenado y energético de conejos en crecimiento. En el experimento 1 se estudió el efecto de la suplementación con un complejo enzimático a diferentes dosis sobre los parámetros productivos, el rendimiento y las características de la canal, la digestibilidad de los nutrientes y el balance del nitrógeno y la energía. En el experimento 2 se utilizó el mismo complejo enzimático que en el experimento 1 pero, en dos piensos diferentes, que variaban en su contenido en ED, PD y FND. El experimento 3 consistió en estudiar el efecto de tres niveles y dos fuentes de LAD. Y, por último, en el experimento 4, se estudió el efecto de diferentes niveles de restricción alimentaria sobre sobre los parámetros productivos, el rendimiento y las características de la canal, la digestibilidad de los nutrientes y el balance del nitrógeno y energía en conejos de cebo. Ninguno de los piensos que se suministraron a los animales estaba medicado.

En el experimento 1, el objetivo fue comparar la inclusión de un complejo enzimático de origen fúngico (actividad de $100 \mathrm{XU} / \mathrm{g}$ pentosanasa, $40 \mathrm{CMC} / \mathrm{g}$ de celulasa, $30 \mathrm{FAU} / \mathrm{g}$ amilasa, $100 \mathrm{XU} / \mathrm{g}$ de xilanasa, $700 \mathrm{HUT} / \mathrm{g}$ de proteasa, $4000 \mathrm{AJDU} / \mathrm{g}$ de pectinasa y $200 \mathrm{BGU} / \mathrm{g}$ de $\beta$-glucanasa) en el pienso de cebo a distintas dosis $(0,100$, 200, 400 y 800 ppm), sobre los parámetros productivos, las características de la canal y el balance nitrogenado y energético de los gazapos en crecimiento. Se utilizaron 225 gazapos destetados a los $34 \mathrm{~d}$ de edad, alojados en jaulas individuales y asignados aleatoriamente en cinco tratamientos. Se formuló un pienso basal (PB: 17,6\% MS; Almidón: 17,4\% MS; FND: 35,9\% MS; EB: 4.319 kcal/kg MS), al que se suplementó 
con las distintas dosis del complejo enzimático. Se controló el consumo y el peso de los animales desde los 34 a los 48 d de edad y desde los 49 a los 60 d. En 11 gazapos por tratamiento, se estimó la composición corporal mediante la técnica de Impedancia Bioeléctrica a los 34 y 60 d de edad para estimar el balance de nitrógeno y de energía. Al final del cebo, 24 gazapos por tratamiento fueron sacrificados y se midió el peso de la canal, de todo el tracto digestivo, del estómago lleno, del estómago vacío y del ciego lleno. Entre los días 53 y 57 de vida, se realizó una prueba de digestibilidad (MS, MO, PB, EE, FND, EB; n=11), excepto para la dosis de 100 ppm. En el primer periodo del cebo (34-48 d), la suplementación enzimática mejoró linealmente $(\mathrm{P}<0,05)$ el índice de conversión (IC), sin afectar el consumo (CMD) o el crecimiento (GMD). En el segundo periodo (49-60 d), tanto el índice de conversión (IC) como la GMD variaron cuadráticamente $(\mathrm{P}<0,05)$ con la suplementación enzimática, siendo el nivel óptimo para ambos: 400 ppm/kg. La digestibilidad de la MS, MO, EB y EE empeoraron linealmente $(\mathrm{P}<0,05)$ y el peso del aparato digestivo $(\% \mathrm{PV})$ aumentó linealmente $(\mathrm{P}<0,05)$ al incrementar la dosis de inclusión del complejo enzimático, sin afectar al rendimiento a la canal, que fue de media 57,8\%. Las enzimas no tuvieron efecto sobre el balance de nitrógeno ni de energía, excepto para la excreción de energía en heces $(\mathrm{P}<0,05)$ que incrementó con la dosis, por la peor digestibilidad de la EB. Ni la composición corporal de los gazapos in vivo a los 60 d de edad, ni la composición de las canales se vieron afectadas $(\mathrm{P}>0,05)$ por el nivel de suplementación del complejo enzimático. En el experimento 2: el objetivo fue comparar el efecto de la suplementación del complejo enzimático en dos piensos con distintos niveles de energía digestible (ED), de proteína digestible (PD) y de FND sobre los rendimientos productivos, las características de la canal y el balance del nitrógeno y energético de gazapos en crecimiento. Para ello, se utilizó el mismo complejo enzimático a tres dosis ( 0,100 y 200 ppm) y se formularon dos 
piensos basales distintos (Pienso A: PB: 17,6\% MS; almidón: 17,4\% MS; FND: 35,9\% MS; ED: 2.797 kcal/kg MS y Pienso B: PB: 15,8\% MS; almidón: 17,5\% MS; FND: 37,4\% MS; ED: $2.585 \mathrm{kcal} / \mathrm{kg}$ MS). Se utilizaron un total de 270 gazapos destetados a $34 \mathrm{~d}$, que fueron alojados en jaulas individuales. Se controlaron los mismos parámetros que en la prueba anterior. La prueba de digestibilidad (entre los días 53 y 57 de vida), se realizó en los dos piensos (A y B) pero sólo para las dosis 0 y 200 ppm. La adición de enzimas no afectó a la digestibilidad ni a ninguno de los parámetros productivos estudiados durante el cebo. El pienso B empeoró $(\mathrm{P}<0,01)$ la digestibilidad de la MS, MO, FND y EB con respecto al pienso A (un 5,98; 5,66; 4,91 y 22,59\%, respectivamente). El consumo de nitrógeno digestible (NDi) y ED fueron menores para el pienso B que para el A (un 10\% y $7 \%$, respectivamente; $\mathrm{P}<0,01)$. Este menor consumo de ND en los animales del pienso $\mathrm{B}$, dio lugar a que, a pesar de que presentaron una mayor eficacia de retención del ND con respecto a los del pienso A (43 vs. 40\%; P<0,05), la retención de ND en la canal fuera un $4 \%$ menor $(\mathrm{P}<0,05)$ y la excreción de nitrógeno en la orina $(\mathrm{P}<0,05)$ y en las heces $(\mathrm{P}<0,05)$ fueran también un 19,4 y un 6,3\%, respectivamente, más bajas. El consumo de ED (0,998 vs. 0,947 MJ/kg PV ${ }^{0.75}$.d; $\left.\mathrm{P}<0,05\right)$, la eficiencia de retención de la energía, tanto corporal (0.389 vs. $\left.0.360 \mathrm{~kJ} / \mathrm{kg} \mathrm{PV}^{0.75} . \mathrm{d}\right)$, como en la canal $(0,231$ vs. $0,211 \mathrm{~kJ} / \mathrm{kg}$ $\mathrm{PV}^{0.75}$.d) fueron menores en el pienso B que en el A. debido a la menor ingestión de energía y a la menor eficiencia de retención, la energía en heces fue mayor $(0,660$ vs. $\left.0,705 \mathrm{MJ} / \mathrm{kg} \mathrm{PV}^{0.75} . \mathrm{d} ; \mathrm{P}<0,05\right)$ en los animales que ingirieron el pienso $\mathrm{B}$, mientras que la energía excretada en piel y vísceras fue mayor en el pienso A $(0,157$ vs. $0,148 \mathrm{MJ} / \mathrm{kg}$ $\mathrm{PV}^{0.75}$.d). La menor retención de $\mathrm{N}$ y de EB del pienso B, dio lugar a un menor peso a 48 d de edad de los gazapos (1650 g vs. $1622 \mathrm{~g}$; $\mathrm{P}<0,05)$, debido a una menor GMD en el primer periodo de cebo $(58,2$ vs. 60,$2 ; \mathrm{P}<0,05)$, aunque en el segundo periodo de cebo y en el peso final no hubo diferencias significativas. El consumo de pienso durante el cebo 
fue un 2,92\% mayor en el pienso B, por lo que el IC empeoró $(2,52$ vs. 2,63; P<0,05). El tipo de pienso no afectó al rendimiento canal, aunque los gazapos del pienso B tuvieron mayor peso del aparato digestivo y del estómago lleno y vacío $(\mathrm{P}<0,05)$. La composición química de la canal se vio afectada por el tipo de pienso $(\mathrm{P}<0,05)$. El pienso A presentó un mayor contenido de EE y de energía $(\mathrm{P}<0,05)$, mientras que el pienso $\mathrm{B}$ tuvo mayor contenido en agua, $\mathrm{PB}$ y cenizas $(\mathrm{P}<0,05)$.

En el tercer ensayo el objetivo fue estudiar el efecto de la inclusión de distintos niveles de lignina acido detergente (LAD) (Bajo (B): 5\% MS; Medio (M): 6\% MS y Alto (A): 7\% MS) y de distintas fuentes de lignina (Arbocel@ (A) vs. granilla desengrasada de uva $(\mathrm{G})$ ) sobre los parámetros productivos, las características de la canal y el balance de nitrógeno y energético de gazapos en crecimiento. Para ello se utilizaron 936 gazapos, 216 fueron destetados a los $34 \mathrm{~d}$ de edad y alojados en jaulas individuales, y los 720 restantes se destetaron a los $35 \mathrm{~d}$ de edad, y se alojaron en jaulas polivalentes (5 gazapos/jaula). Se formularon cinco piensos distintos: un pienso control para ambas fuentes (AB y GB: ED: 2939 kcal/kg MS; PB: 18,4\% MS; FND: 36,4\% MS; FAD: 21,3\% MS; LAD: 4,78\% MS; Almidón: 15,5\% MS), dos piensos con un nivel medio para cada fuente (AM (ED: 2825 kcal/kg MS; PB: 17,7\% MS; FND: 37,8\% MS; FAD: 23,8\% MS; LAD: 5,87\% MS; Almidón: 15,1\% MS) y GM (ED: 2909 kcal/kg MS; PB: 17,9\% MS; FND: 36,2\% MS; FAD: 21,8\% MS; LAD: 6,03\% MS; Almidón: 15,6\% MS)) y otros dos piensos con un nivel alto para cada fuente (AA (ED: $2848 \mathrm{kcal} / \mathrm{kg}$ MS; PB: 18,1\% MS; FND: 37,7\% MS; FAD: 23,8\% MS; LAD: 6,23\% MS; Almidón: 14,5\% MS) y GA (ED: 2908 kcal/kg MS; PB:17,6 \% MS; FND: 35,4\% MS; FAD: 22,0\% MS; LAD: 6,72\% MS; Almidón: 15,9\% MS)). En el cebo colectivo, se controló el peso y el consumo de cada jaula al inicio y al final del cebo (35 y 61 d de edad), y el índice de conversión y la mortalidad diaria. En el cebo individual se controló el consumo medio diario y el peso en 
dos periodos, de 34 a 48 d y de 49 a 60 d de vida, así como el índice de conversión y la mortalidad diaria durante el cebo. En 11 gazapos por tratamiento, se estimó la composición corporal mediante la técnica de Impedancia Bioeléctrica a los 34 y 60 d de edad para estimar el balance de nitrógeno y de energía. Al final del cebo, 24 gazapos por tratamiento fueron sacrificados y se midió el peso de la canal, de todo el tracto digestivo, del estómago lleno, del estómago vacío y del ciego lleno. Entre los días 53 y 57 de vida, se realizó una prueba de digestibilidad (MS, MO, PB, EE, FND y EB; n=11). En el cebo colectivo el nivel más alto de lignina afectó al IC, respecto a los otros dos niveles $(2,65$ de media $v s .2,69 \mathrm{~g} / \mathrm{g}, \mathrm{P}<0,05)$, sin que variase la ingesta $(139 \mathrm{~g} / \mathrm{d})$ ni el crecimiento $(52,2$ g/d). En el cebo individual el peso del aparato digestivo (\%PV) disminuyó con los niveles medio y alto de lignina, con respecto al control $(17,4$ de media $v s .17,9 \% ; \mathrm{P}=0,05)$ sin afectar al rendimiento a la canal (58,2 \% de media). La digestibilidad aparente de la MS, MO y EB del pienso con el nivel más bajo de LAD fue mayor con respecto a la media de los otros dos: MS (58,3 vs. 56,8\%), MO (60,2 vs 58,8\%), EB (60,2 vs. 58,9\%). La digestibilidad aparente de la PB del nivel medio fue menor que la del nivel más bajo (70,1 vs. $72,6 \% ; \mathrm{P}=0,05)$ y el pienso con el nivel alto de LAD presentó un valor intermedio (71,0\%). La digestibilidad del EE aumentó con el nivel de inclusión de LAD (84,7; 85,8; $88,0 \%$, respectivamente). Los animales del nivel alto de LAD, consumieron menos ND que los de los niveles medio y bajo (1,901 vs. 1,992 g NDi/kg PV.75. $\mathrm{d}$, de media; $\mathrm{P}<0,05)$, y tendieron a mejorar la eficiencia de retención $(0,348$ vs. 0,338\%, de media; $\mathrm{P}<0,05)$, por lo que el $\mathrm{N}$ retenido en todos los niveles de LAD fue similar $\left(0,669 \mathrm{~g} \mathrm{~N} / \mathrm{kg} \mathrm{PV}^{0,75} . \mathrm{d}\right)$. La excreción de $\mathrm{N}$ en orina fue menor para los dos niveles más altos de lignina (0.894 de media vs. 1,003 g N/ kg PV ${ }^{0,75}$.d). Por el contrario, la excreción de energía en heces en estos dos piensos aumentó (+5\%), con respecto al nivel de LAD más bajo. La inclusión de Arbocel@ como fuente de LAD empeoró el IC en el cebo individual (2,56 vs. 2,52 g/g; 
$\mathrm{P}<0,05)$, así como en el colectivo $(+1,42 \%, \mathrm{P}<0,05)$. El Arbocel® empeoró la digestibilidad de MO, respecto a la granilla desengrasada de uva $(56,9$ vs. 57,7\%; $\mathrm{P}<0,05$. La composición química de la canal no se vio afectada ni por la fuente ni por el nivel de LAD del pienso.

El objetivo en el experimento 4 fue estudiar el efecto de diferentes estrategias de restricción en los conejos durante el cebo. Se utilizaron un total de 600 gazapos, destetados a $34 \mathrm{~d}$, alojados en grupos (5 animales por jaula; 24 jaulas/tratamiento) y asignados aleatoriamente en uno de los cinco tratamientos: grupo control (AL), consumo ad libitum, y los otros cuatro tratamientos que fueron restringidos un 80 y $70 \%$ del consumo teórico ad libitum (R80 y R70, respectivamente), durante todo el cebo o solo hasta los 48 d de vida (R80AL y R70AL, respectivamente). Se formuló un solo pienso (PB: 159 g/kg MS; FND: 324 g/kg MS; ED: 2.689 kcal/kg MS). Al final del cebo, se sacrificaron 24 conejos por tratamiento y se midieron los pesos de la canal y de los órganos digestivos. La prueba de digestibilidad se realizó en jaulas metabólicas individuales entre los 53 y 57 d de vida (12 gazapos/tratamiento). La restricción alimentaria empeoró ( $\mathrm{P}<0,001)$ el índice de conversión $(1,93$ vs. 1,82 g/g, de media) y la ganancia media diaria (42,4 vs. 60,3 g, de media) de 34 a 48 d de vida. Sin embargo, de 48 a 61 d de edad hubo un crecimiento compensatorio en los gazapos realimentados a ad libitum (R80AL y R70AL) cuando terminó el periodo de restricción (61,1 vs. 46,4 g/d, de media). Durante todo el cebo, el crecimiento compensatorio condujo a una mejora del índice de conversión $(2,25$ vs. 2,33 g/g; P < 0,001), y los conejos del tratamiento R80AL terminaron el cebo con un peso vivo similar que el grupo control. Los órganos internos aumentaron $(\mathrm{P}<0,05)$ su tamaño cuando los gazapos se realimentaron ad libitum, sobre todo en aquellos restringidos al $70 \%$ durante la primera fase. La mortalidad media fue del $12,8 \%$ y, los diferentes tratamientos no tuvieron ningún efecto. La digestibilidad de la 
proteína en los tratamientos R80 y R70 tendió a aumentar en los animales restringidos hasta los $48 \mathrm{~d}$. La digestibilidad del resto de nutrientes no se vio afectada por ninguna de las estrategias de restricción. La concentración de nitrógeno y de cenizas en la canal aumentó, mientras que el contenido en energía y grasa disminuyó en todo el cebo en los grupos restringidos $(\mathrm{P}<0.001)$. La eficacia de retención del nitrógeno tendió a aumentar $(\mathrm{P}=0.074)$ y la excreción de nitrógeno en heces y las pérdidas por orina + calor disminuyeron $(\mathrm{P}<0.001)$ en los animales restringidos.

De los resultados de estos cuatro ensayos se puede concluir que el suministro del complejo enzimático en los piensos de gazapos en crecimiento no mejoró la digestibilidad, la excreción de nitrógeno al medio, ni redujo el peso del aparato digestivo, aunque no tuvo un efecto negativo sobre el rendimiento de la canal. La utilización de enzimas mejoró el índice de conversión en la primera etapa del cebo, por lo que su uso sería recomendable en animales jóvenes tras el destete. En las condiciones de este estudio, la adición de enzimas a un pienso menos digestible tampoco mejoró la eficacia de utilización de los nutrientes, ni tuvieron efecto sobre rendimiento de la canal. La inclusión de niveles de LAD por encima de un 5\% en piensos isoenergéticos, disminuyó el peso del aparato digestivo, aunque este efecto no se vio reflejado en una mejora del rendimiento de la canal. El Arbocel® empeoró el IC sin afectar al crecimiento. La restricción hasta los 48 d podría ser una herramienta útil para reducir el impacto ambiental de las granjas, sin perjudicar los rendimientos productivos ni el rendimiento de la canal en todo el periodo de cebo.

En condiciones donde no hay incidencia de enteropatía ninguna de las estrategias estudiadas tuvo efecto sobre la mortalidad. 


\section{INTRODUCTION}




\section{INTRODUCTION}

The goal of every meat production system is to get a carcass and final product of quality with the final purpose to optimize not only the zootechnical parameters, but also the economic benefit. Meat quality refers to its nutritional, sensory, technological, and sanitary characteristics (Dalle Zotte, 2002); and carcass quality to the carcass yield, ratio meat/bone or the proportion of certain muscle with higher commercial value (Blasco et al., 1982)

In this sense, previous studies in other species, like cattle (Berg and Butterfield, 1979) proposed as a logical aim in the production the increased of the total muscle mass, based in the fact that in a same point of the growing curve, it seems, not to be differences in the distribution of muscle masses among dairy and beef bovine breeds. The difference in the muscle masses distribution is based in the precocity of the lines. On the other hand, Richmond and Berg (1971) in swine and Fourie (1965) in sheep reached similar conclusions, setting as main target in production the increase of the total meat in the carcass. In rabbits, like in other species, the most effective way to improve this parameter is by the genetics (Hernández et al., 2004; Pascual and Pla, 2007), due to the high cost that normally would supposes to increase the muscle mass by nutrition. It could be reached by increasing the energy and protein feed supply, what could compromise the profitability of the farms, due to the price increase of the raw materials in the last years.

Moreover, it has been demonstrated that the inclusion of high protein levels in rabbit's feed increases the nitrogen emission to the environment and causes digestive pathologies. In addition, in Spain it is applied the European Regulation about the contamination of the environment (Regulation EC N ${ }^{\circ} 1069 / 2009$ ); therefore, the demand to decrease the residues produced in the farms due to their potential contaminant effect in 
the environment has been increased (Royal Decree 1528/2012, 8th of November), imposing ever-increasing sanctions to the farms that do not comply with these regulations.

On the other hand, the awareness of the consumers about the environment has been increasing and demand the minimum environmental impact. Thus, for the nutritional point of view is interesting to look for strategies that improve the performance and carcass quality keeping or reducing the residues produced. At the same time the consumer is looking more for a healthy diet demanding more lean meat and good quality fat intake.

However, nutrition can play a role in carcass yield and composition. Some strategies have been already tested, like different feed formulations and feed supplements. For example, the use of exogenous enzymes in feed for rabbits could have an effect on the carcass due to its capacity to improve the nutrients digestibility, reduce emissions to the environment and decrease the digestive content (Falçao-e-Cunha et al., 2007). Another way to improve this parameter would be the inclusion of high levels fibre that increases the passage rate of the digesta (Gidenne et al., 2001; de Blas et al., 1999) and the emptying of the digestive tract (Nicodemus et al., 1999; García et al., 2002a). Therefore, the increase of the carcass yield, by reducing the content and/or size of the digestive tract, would suppose a lower environmental impact due to the reduction of the wastes that must be disposal, and due to the better productivity in the slaughterhouse. 
LITERATURE REVIEW 


\section{LITERATURE REVIEW}

\subsection{Carcass quality for the different links of the food chain}

The concept of carcass quality differs among each sector and step of the meat production industry (Ouhayaun, 1998). The variety of interests makes difficult to give a unique definition of quality valid for all the food chain levels and sometimes even impossible to satisfy every target: sensorial, dietary, or technological. Following there is a short description of the quality concept for each step of the food chain: farmer, slaughterhouse or industry, butcher or retailer and customer.

\section{Farmer:}

For the farmer, the main interest is to optimize the growth and performance parameters of the animals. Its main objective is to produce saleable animals in the less time possible at the lowest cost, complying at the same time with the weight, formation, and fat cover demanded by the industry. In practice, the variability in the carcass fat cover and weight can be responsible, largely, of its value.

The farmer has to take into account also the demand of the final consumer and get carcasses that fit with that demand. However, usually what is commercially most valuable as the highest quality is not the most profitable, either because the cost increase considerably or because the productive potential is lost (Consigli, 2001), making it necessary to find an optimal balance.

\section{Slaughterhouse or industry:}

The industry requires carcasses with the maximum proportion of muscle, the minimum of bone and a proper amount of fat, according to market demand. 
Its priority is to acquire animals with a good carcass yield, good profiles, and presence of certain level of fat, mainly fat cover. The fat and its distribution are an aspect of maximum interest in the sale of the carcasses (Berg and Butterfield, 1979), by its own importance and because of the tight relation with the muscle.

\section{Butcher (retailer):}

The butcher looks for satisfy the customer's demand, but this, in turn, depends on the carcasses that the slaughterhouse has or sells in each moment. In consequence, they must consider these factors taking into consideration the size of the pieces and the amount of fat (ratio muscle/bone and muscle/fat). Obviously, the retailer centres its priority in the carcasses with high proportion of premium pieces, that have higher demand and are, therefore, easily sold at a higher price.

\section{Consumer:}

The consumer generally demands a meat with high content of muscle and some fat. They also consider, largely, the colour and tenderness as acceptance parameters. However, the demands of the consumer are many and diverse, and could been summarized as follow:

- Appearance: meat and fat colour, shape, and weight of the piece.

- Composition: proportion of meat and fat in the pieces and the residues left in the plate.

- Organoleptic characteristics: tenderness, flavour, juiciness, and satisfaction aroused when is eaten. 


\subsection{Rabbit commercial carcass in Spain}

The best economic moment to slaughter the animals is when they reach a live weight (LW) between 2 and $2.8 \mathrm{~kg}$, that are reached at the age of 8 to 10 weeks of life, respectively, with a carcass yield that vary between 54 to $61 \%$. Since the accumulation of fat starts from the $2.5 \mathrm{~kg} \mathrm{LW}$, the demands of the consumer are met, because they prefer tender and lean meats. In the Mediterranean countries, where the rabbit meat consumption is higher, the slaughtered weights vary, being Spain the country with the lowest weight (Table 1).

Table 1. Average carcass weights demanded in Spain, France, and Italy. COUNTRY CARCASS WEIGHT $(\mathrm{kg})^{*}$ CARCASS WEIGHT $(\mathrm{kg})^{* *}$

\begin{tabular}{lll}
\hline Spain & $1.0-1.2$ & 1.2 \\
France & $1.4-1.6$ & 1.4 \\
Italy & $1.4-1.6$ & 1.5 \\
\hline
\end{tabular}

*Camps (1993). **FAO (2013)

Carcass is defined as the remains of a dead animal after bled and skinned. Another particularity of Spain is that the carcass is normally sold with head, kidneys, and liver (Blasco et al., 1993). The carcass weight demanded by the market are 1-1.2 kg, therefore, the rabbits are slaughtered with two months of age and around $2 \mathrm{~kg}$ of $\mathrm{LW}$. The average carcass weight is around $60 \%$, with a fat content lower than $5 \%$ and less than $20 \%$ of bones (Ouhayoun, 1998).

Actually, carcasses are presented entire or cut. The typical cutting consists in seven cuts: the two hind legs, two front legs, the loin (premium pieces) and two thorax portions (second category pieces). However, the processing of the rabbit meat is lapping behind in comparison with other species (Petracci et al., 2012). 


\subsubsection{Carcass yield}

The carcass yield is one of the most used technical parameters to evaluate the carcass quality and one of the most important, economically, for the slaughterhouse.

According to the rules of the World Rabbit Scientific Association collected by Blasco et al. (1993) and modify by Blasco and Ouhayoun (1996) to unify the definitions of some of the parameters used on researches about rabbits, carcass yield is defined as:

- Hot Carcass Weight (HCW): Weight of the carcass 15-30 min after slaughter.

- Chilled Carcass Weight (CCW): Weight of the hot carcass after chilling for 24h between $0-4^{\circ} \mathrm{C}$.

- Standardized Live Weight (LW): Liveweight of rabbits at the end of the experimental period before fasting, digestive tract content and urinary bladder must be included.

- Slaughter Live Weight (SLW): Live weight of the rabbit before the slaughter.

- Empty Live Weight (ELW): SLW without digestive tract.

The differences between LW and SLW are due to losses caused by fasting, droppings and dehydration during transport and vary from 2 up to $3.5 \%$ (Villena et al., 2008; Mazzone et al., 2010; Margüenda et al., 2012), and can be even up to 4.5\%, when the transport to the slaughterhouse is longer than 8 hours (Trocino et al., 2003).

Depending on the weights uses there can be different definitions of carcass yield:

- Dressing out Percentage (DoP): ratio, expressed in percentage, between the chilled carcass weight and the live weigh of the animal: CCW/LW x 100.

- Slaughterhouse Yield: CCW/SLW x 100.

- $\quad$ Real Yield: CCW/ELW x 100. 
Despite the most common is the dressing out percentage, it is important to indicate which one is used. Even if the farmers are paid according to the animals LW, being the DoP of technical and economic importance mainly for the slaughterhouses, there is a tendency to pay in the future to the farmer according to the carcass quality and DoP (Such, 1981). Nowadays, rabbit carcass yield varies between 50 and $65 \%$ of LW. This wide variation is due, partly, to the criteria used for its definition (dressing out percentage, slaughterhouse or real yield), but there are also other factors that can be intrinsic, specific of each animal (genetic, breed, slaughter age (from 8 to 12 weeks), slaughtered weight) or extrinsic, like the environment of the animal and its management (environmental conditions, feeding during the fattening phase, fasting before slaughtered) (Such, 1981, Ouhayoun, 1991a, Parigi Bini et al., 1992; Bianospino et al., 2006; and Metzger et al., 2006). In Figure 1 is shown the typical commercial cutting of a $2.3 \mathrm{~kg} \mathrm{LW}$ rabbit. The digestive tract is approximately the $20-21 \%$ of the LW, which represents the $60 \%$ of the total wastes produced in the slaughterhouse (Margüenda et al., 2012).

Due to the European legislation about Transmissible Spongiform Encephalopathy the wastes produced in the slaughterhouses are consider hazardous material and must be disposed, normally by incineration, what results in an added cost (Margüenda et al., 2012). 
Figure 1. Commercial cutting of a $2.3 \mathrm{~kg}$ live weight rabbit (Ouhayoun, 1991a).

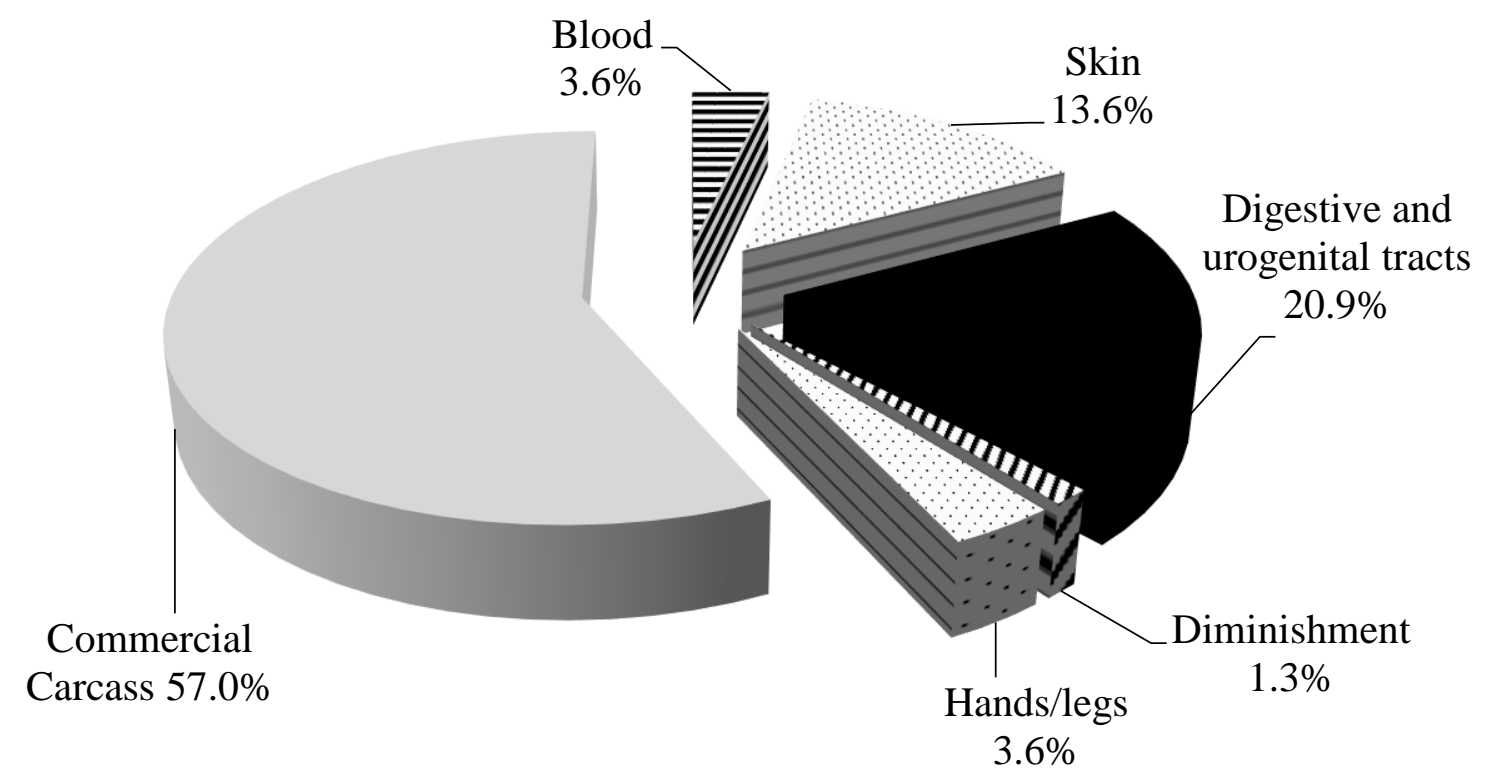

\subsubsection{Factors influencing on the carcass yield}

\subsubsection{Carcass presentation}

The diversity of carcasses presentations is one of the most important causes of the variation in the DoP. For example, in Spain, the head is part of the carcass, while in other countries not. Therefore, is not consider for the DoP calculation.

\subsubsection{Intrinsic (genetic, sex and age)}

In this group are considered the parameters that depends on the animal. Basically, genetic, sex and age.

\subsection{Genetic}

Carcass characteristics are basically influenced by the adult weight and by the maturity of the rabbits at slaughter (Pla et al., 1996; Piles et al., 2000, Dalle Zotte, 2002, Metzger et al., 2006). If rabbits are sacrificed at the same age, the breeds that reach before the adult weight have a lower carcass yield that those that have a later maturity (Such, 
1981, Lukefahr et al., 1982; Maertens, 1992; Pla, 1996; Pla et al., 1996; Dalle Zotte and Ouhayoun, 1998). This is partially due to the positive allometry presented by the growth of the intestinal tract (Cantier et al., 1969; Deltoro and López, 1985) in relation to the total body weight, that makes, proportionally, higher the digestive tract weight regarding the LW in the animals with faster growth than in the slower ones (Ouhayoun, 1998). On the other hand, Hernández et al. (2004) observed that when genetically different animals are sacrificed at the same maturity status, at different ages, there are no differences on the DoP due to the genetic improvement. Therefore, if the target were only to obtain the maximum carcass yield, it would be interesting to slaughter the animals with a higher weight in genetically similar breeds. However, the heavier the animals, the higher the proportion of fat and lower the ratio muscle/bone (Hernández et al., 2004). If a rabbit reaches its adult weight at $4 \mathrm{~kg}$, the adiposity increases from $2100 \mathrm{~g}$ and, the ratio muscle/bone will tend to decrease from $2450 \mathrm{~g}$ of LW, whereby the optimal slaughter weight would be around $2300 \mathrm{~g} \mathrm{LW}$ (that gives carcasses of $1300 \mathrm{~g}$ ).

In Spain rabbits are sacrificed with less than 55\% the adult weight, what improve the feed conversion ratio (FCR) and produce carcasses with less fat content but worse dressing out percentage. Carcass weights over $1430 \mathrm{~g}$ have a $6 \%$ higher DoP (Ouhayoun, 1991a).

According to Metzger et al. (2006) in order to increase the meat content, the genetic selection in late growth breeds should be done selecting by both growth rate and carcass traits at an earlier age.

\subsubsection{2. $\underline{\operatorname{Sex}}$}

In most of the species males have higher growth potential than females and reach earlier the adult weight. Males carcass weight is also heavier, and its carcass composition 
is leaner than the females (Lazzaroni et al., 2009). However, these differences are not relevant in the rabbit (Bernardini et al., 1995) because they are slaughtered much earlier that they reach the puberty, period when it starts to show up more the differences. In this sense, Trocino et al. (2003) observed that females had lower carcass yield and higher losses during transport until the slaughterhouse than males, although in this study rabbits were slaughtered with more than $2.5 \mathrm{~kg} \mathrm{LW}$, much higher than in Spain.

\subsubsection{3. $\underline{\text { Age }}$}

The age is a factor with high importance on the DoP. Many authors (Parigi Bini et al., 1992; Piles et al., 2000; Dalle Zotte, 2002 and Gondret et al., 2002) have confirmed that the older, the higher the carcass yield up to an optimum and then decreases. The age is link to the live weight of the animal, because the older the animal, the heavier it is. Therefore, all these works concluded that is convenient to do comparison among breeds or genetic lines at a same slaughter age to avoid differences attributed to the somatic maturity. Nevertheless, despite the age improves the DoP impairs the feed conversion and the carcasses are fatter (Fernández and Fraga, 1996), consequently it is important to find a compromise among all these variables to optimize the economic profit.

\subsubsection{Extrinsic (management, environment, feeding)}

These factors refer to the environment where the animals are and the factors that do not depend on the animal itself.

\subsection{Management}

Among these factors are those related to the type of housing, the density during the fattening period, and the conditions before slaughter, such as fasting and transport. Some studies have shown that group housing in cages during the fattening period with more 
space and straw litter worse the DoP compared to conventional cages (Dal Bosco et al., 2002; Metzger et al., 2003; Lazaroni et al., 2009). Housing systems on the ground with access to the outside (D'Agata et al., 2009) also reduced the DoP, as well as extensive versus intensive breeding systems (Rymkiewicz and Lewczuk, 1999; Bielański, 2000). However, in other studies no effect of the housing system on DoP have been found (Daszkiewicz et al., 2012). The density can also affect the DoP but high densities seem to have a more negative influence on productive parameters than on DoP (Aubret and Duperray, 1992; Xiccato et al., 1999; Paci et al., 2013). According to Martínez and Fernández Carmona (1981) the group creates a microclimate that dampens the variations of the environment but can be counterproductive in hot periods. However, even under conditions of heat stress Villalobos et al. (2008) did not observe negative effects of a higher density on DoP.

Fasting prior slaughter also affects the DoP. During the first 6 hours of fasting, the animal weight losses are mainly due to the emptying of the digestive system, while during the next 6 hours there is also moisture and nutrients losses from the body tissues. In several studies (Masoero et al., 1992; Szendro y Kustos, 1992; Trocino et al., 2003; Margüenda et al., 2008 and 2009) have been observed that the animals fasted before slaughter presented a lower weight of the digestive system and, therefore, greater carcass yield.

\subsection{Environment}

The time of the year, the room temperature, the hygienic-sanitary conditions, etc. are parameters that affect the growth of the animals and therefore the DoP. In rabbits, the increase in environmental temperature above the thermoneutrality values reduces feed consumption (Martínez and Fernández Carmona, 1981; Cervera and Fernández 
Carmona, 2010) and consequently, also reduces the growth rate. This causes a lower slaughter weight, which is more evident in the summer, but sometimes improves DoP due to a lower proportion of skin, intestines and waste (Chiericato et al., 1993 and 1996).

\subsection{Feeding}

The improvement of DoP through feeding is based on two strategies, the first would be through an increase in the carcass weight due to a greater deposition of protein and / or fat, and the second would consist in achieving a reduction in the relative weight of the digestive system. Carcass weight increased through a greater amount of protein and energy intake does not have much interest since the protein is expensive and in addition, the excess nitrogen is polluting (Maertens et al., 1997), and causes digestive disorders (Carabaño et al., 2009). An overconsumption of energy would also lead to more fatty carcasses, which are less valued by consumers. Therefore, below are some of the strategies that can be used to decrease the relative weight of the digestive system:

\subsection{Decrease the feed consumption:}

When the feed energy concentration is higher than $9-9.5 \mathrm{MJ} / \mathrm{kg}$, the rabbits regulate their intake by the energy content. Below this energy value there is a physical regulation, not metabolic (Xiccato and Trocino, 2010). One way to increase the feed energy level is adding fat. In some studies it has been observed that a low or moderate level of fat inclusion (2-6\%) increases the DoP (Raimondi et al., 1974; Castellini and Battaglini, 1992), but in most of the papers it has not been found effect of fat addition on DoP (Partridge et al., 1986; Santomá et al., 1987; Fernández and Fraga, 1996).

Another alternative to reduce the consumption would be to use a DP/DE ratio (g digestible protein/MJ digestible energy) below the recommendations (10 g DP/MJ DE; 
De Blas and Mateos, 2010), although this alternative would be convenient at the end of the fattening phase in order not to adversely affect the growth of the animals. In swine, strategies of this type have already been studied, replacing conventional feed with barley at the end of the fattening period to improve the carcass yield and obtain fatter carcasses (Garitano et al., 2012).

\section{a) Feed restriction:}

Feed restriction could be considered more a management strategy than feed strategy, however, the target is to decrease the feed consumption of the animals. The information of its impact on the carcass yield is scarce and the not always positive (Birolo et al., 2016; Kdunsen et al., 2017).

This strategy has been implemented in the farms mainly to reduce the mortality and morbidity caused by ERE and to decrease the preventive usage of antibiotics. It is commonly used in some countries, like France or Italy, with good success in reduction of mortality and morbidity and for improving feed conversion, especially due to the compensatory growth when the animals are fed ad libitum again (Gidenne et al., 2012; Birolo et al., 2016).

Several post-weaning restriction strategies have been studied. Varying the length and period of application ( 1 to 5 weeks), the intensity (from $90 \%$ to $40 \%$ of the voluntary intake) or the method used (quantitative restriction, water restriction, limited access time to the feeder). Some authors (Di Meo et al., 2007; Tumová et al., 2007; Gidenne et al., 2009a and b) have observed an improvement on nutrient digestibility when restricting the voluntary feed intake. However, these results are not consistent (Gidenne et al., 2012). 


\subsection{Increase the digestive transit}

Fibre plays an important role in the regulation of digestive transit (Fraga et al., 1991; Gidenne and Pérez, 1994; García et al., 1999), control of intestinal microbiota and maintenance of mucosal integrity (De Blas et al., 1999; Gidenne, 2003; Gidenne and García, 2006).

\section{a) Definition of fibre:}

The European Commission define the fibre for humans in the regulation 1169/2011/EU that was applied on 13th of December 2014, as 'carbohydrate polymers with three or more monomeric units (degree of polymerization $\geq 3$ ), which are neither digested nor absorbed in the human small intestine, belonging to the following categories: a) edible carbohydrate polymers naturally occurring in the food as consumed; b) edible carbohydrate polymers, which have been obtained from food raw material by physical, enzymatic or chemical means and, which have a beneficial physiological effect demonstrated by generally accepted scientific evidence; c) edible synthetic carbohydrate polymers which have a beneficial physiological effect demonstrated by generally accepted scientific evidence'.

Dietary fibres are defined as polysaccharides and associated substances resistant to mammal enzyme digestion and absorption, that can be partially or totally fermented in the gut (Gidenne, 2015). Cham et al. (2003) provided a concise synopsis of various views regarding the classification of dietary fibres. The overall tendency is towards an extension of the definition by including resistant starches as well as non-digestible oligosaccharides, and it was recently revisited by De Vries et al. (2010) to develop an official enzymaticgravimetric method that recovers all fibre components of the feed. 
Fibre is one of the main components in the commercial diets for rabbits in intensive rearing. These feeds usually include a third part of forage and fibrous byproducts (De Blas et al., 1999). The different fractions of the fibre are one of the most important nutritional factors for the digestive physiology in the rabbit (De Blas et al., 1999), and the usage of the sequential method developed by Van Soest et al. (1991) (NDF, ADF and residue in ADL), officially recognized by AFNOR (1997), has improved the fibre recommendations in fibre to reduce digestive disorders in young rabbits for fattening (Gidenne, 2000; García-Ruiz et al., 2006). In addition, this method has the advantage to estimate different fractions of the fibre with only one sample (Gidenne, 2000).

\section{b) Lignin:}

The lignin is a cross-linked polymer of aromatic subunits formed by the union of various phenylpropanoid acids and alcohols (coumaryl, coniferyl and sinapyl). The random linkage of these radicals creates a complex and branched three-dimensional structure with a high molecular weight. This structure serves as a matrix for other polysaccharides compounds, providing rigidity and resistance to the cell wall against compression to external agents, like microorganisms, preventing the penetration of destructive enzymes into the cell wall. It also provides hydrophobic properties to the cell wall making them impermeable to water (Whetten and Sederoff, 1995).

Lignin is the most limiting factor in terms of availability of the plant cell wall compounds for the animal digestion (Van Soest, 1994). It is covalently bound to the hemicellulose (Van Soest, 1994) and, therefore, the level of lignification of the NDF negatively influences the hemicellulose digestibility (Gidenne et al., 2010a). It is considered almost undegradable, however, has been observed positive values in the lignin 
digestibility that might be caused more by its solubilization than its hydrolysis. Some sources of lignin are:

b.1) Defatted grape seed meal:

A by-product from the wine industry and is formed by the seeds of the grape. The seeds are compound by a tegument or cover very lignified and by albumen rich in lipids. The oil has a high commercial value and, therefore, is usually extracted with hexane. The resulting product is called defatted grape seed meal (1-2\% of ether extract) and content approximately a 50\% of crude fibre and a high content of ADL (42\%) (FEDNA, 2019). This material is normally sold as meal and presents the advantage that is sterilized in the oil extraction process. Sometimes is market complete and mixed with other wine byproducts (skin and stalk) being all together the grape marc. In a study done by García et al. (2002a) observed that the inclusion of a $15 \%$ of defatted grape seed meal promoted feed ingestion, improved DWG and the specific activity of the disaccharidases in the small intestine of growing rabbits, without alter the caecum fermentation.

\section{b.2) Arbocel@:}

A lignocellulose derived from wood by-products with a high lignin content. In a trial performed by Krieg et al. (2008), where the ratio lignin-cellulose was increased with a 3\% Arbocel®, suggested that this increase could reduce fibre digestibility and decrease the microbial fermentation rate.

The fibre level influences the weight of the cecum content, and therefore the weight of the digestive system. Figure 2 shows how the feed NDF level influences quadratically the cecum content weight in growing rabbits (de Blas et al., 1999). The minimum weight of the cecum content is obtained for a $39.5 \mathrm{NDF}$ (\% DM) and values 
above or below this optimum produce an increase in the cecum content weight. However, the same level of NDF can lead to different results, depending on the type of fibre: and if it is more or less lignified (Fraga et al., 1991; Nicodemus et al., 1999; García et al., 1999), more or less fermentable (Gómez-Conde et al., 2009, Trocino et al., 2011; MartínezVallespín et al., 2013) or larger or smaller particle size (Gidenne, 1993; Nicodemus et al., 2006; Romero et al., 2011).

Figure 2. Effect of the neutro detergent fibre (NDF) on the weight of the cecum content (CCW; \%LW) (De Blas et al., 1999).

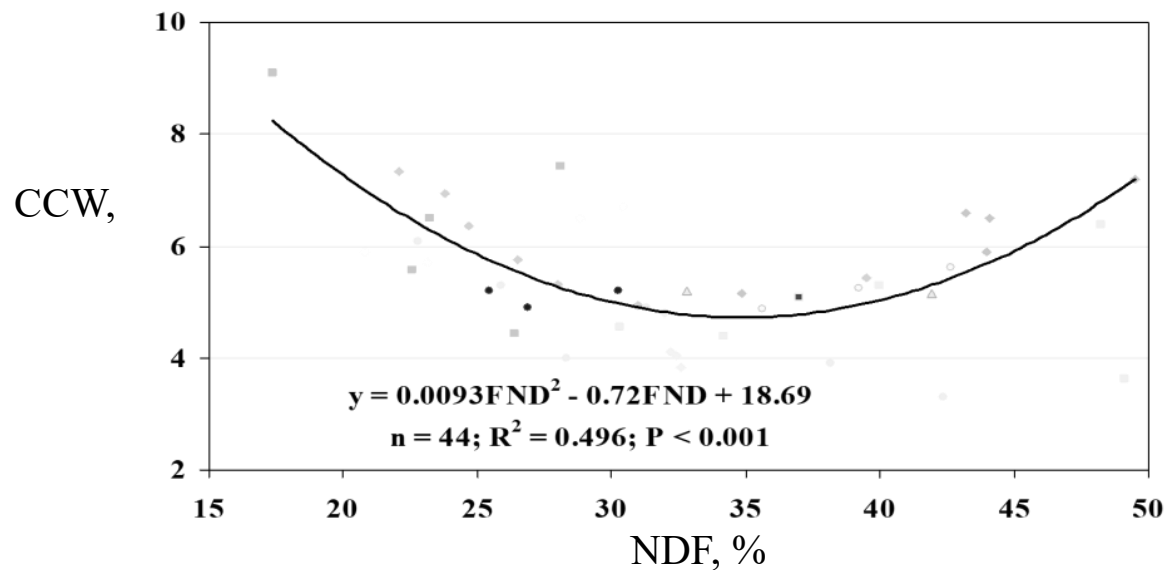

In terms of DoP, decreasing levels of fibre and its corresponding raising level of starch increase the caecum content of the rabbits (Dehalle, 1981; De Blas et al., 1986; García et al., 1993), a sign of the longer retention time of the digesta in the caecum. While in high fibre diets higher stomach content was found (De Blas et al., 1986; Parigi Bini et al., 1994), due basically to the higher ingestion level. These variations could be considered to modify the DoP (Xiccato, 1999) that, in general, is impaired by a higher digestive tract weight. Some studies have observed an increased DoP with increasing levels of NDF of the feed (Fabre et al., 2006; Liangzhan et al. 2017); provided always at a level close to the optimum that minimizes the weight of the cecum content. However, an excess of NDF could worsen the DoP as have been observed by Magüenda et al. (2006 and 2012); Villena et al. (2008) and Trocino et al. (2011). 
Not only the fibre level, but the more fermentable and less particle size fibres support an accumulation of digesta in the cecum because they cause a longer time of ileum-rectal retention (Gidenne, 1993; García et al., 1999; Nicodemus et al., 2006). Consequently, they can worsen the DoP (García et al., 1993), although moderate inclusions of this type of fibres seem to have no negative effects on the DoP (Trocino et al., 2011; Margüenda et al., 2012). In fact, currently it is recommended the inclusion of moderate levels of soluble fibre (11-12\%; Martínez-Vallespín et al., 2011; Trocino et al., 2013; Delgado et al., 2018) in order to avoid the use of antibiotics and prevent the epizootic rabbit enteropathy (ERE).

On the contrary, more lignified fibres accelerate the digestive transit (Pérez et al., 1994; Gidenne et al., 2001) and reduce the weight of the cecal content (Nicodemus et al., 1999; García et al., 2002b; Caîsin et al., 2020). Figure 3 shows how an increase in the ADL concentration of the feed, linearly decreases the cecal content weight, so it could also improve the DoP.

In addition, several studies indicated that all the factors that increase the retention time (decreased levels of fibre, reduction of feed particle size) contribute to disrupt the caecum microbial activity and encourage the enteritis (Gidenne et al., 2010b). In this sense, Nicodemus et al. (1999) recommended a minimal ADL concentration of around $4.1 \%$ in growing rabbits to ensure the growth performance and health of the animals. It has been observed that a high or low level of ADL in diet can negatively affect the passage rate and change caecal fermentation (pH and VFA concentrations) (García et al., 1999, 2000 and 2002b; Gidenne et al., 2001). However, the usage of raw materials rich in lignin in other areas of animal nutrition is increasing the prices (Colin et al., 2007). In this context, products rich in fibre like grape and wood by-products are interesting as a supply of lignin and cellulose for animal nutrition after being crushed and dried. 
Figure 3. Effect of acid detergent fibre (ADL) level on the average retention time of the digesta (ART) in caecum and on the cecum content weight (CCW) (García et al., 2002b).

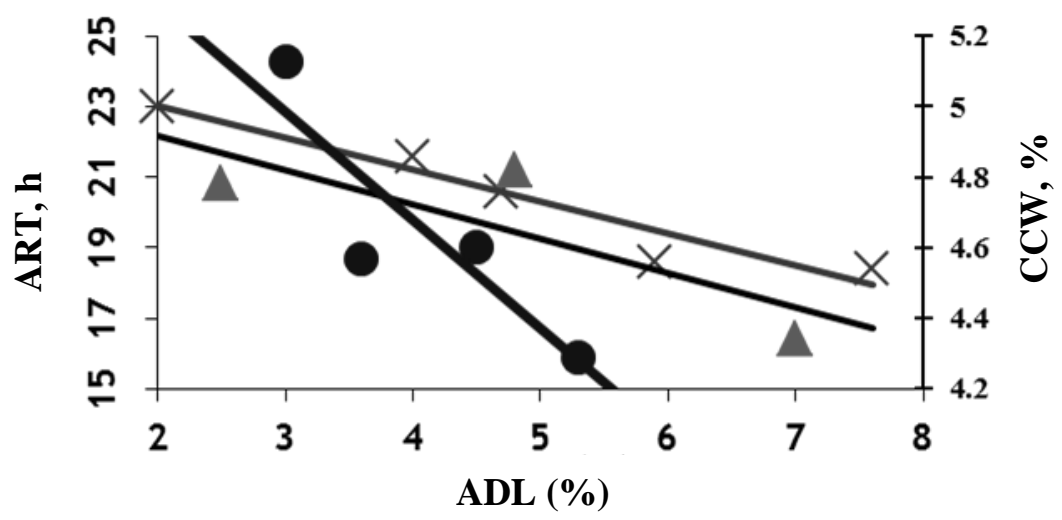

$\multimap$ Pérez et al., $1994 \quad \Delta \quad$ Gidenne et al., $2001 \quad \bullet \quad$ Nicodemus et al., 1999

\subsection{Increase the digestibility}

An improvement of nutrients digestibility promotes its absorption, reduces the flow of fermentable elements to the caecum and therefore, could reduce the relative weight of the digestive system and the cecum content, improving the carcass yield, decreasing the wastes at the slaughterhouse and in consequence, decreasing the cost of the disposal removal and reducing the environmental contamination (Margüenda et al., 2012). A strategy to improve digestibility is to use different additives such as enzymes, organic acids, prebiotics, probiotics (Falcao-e-Cunha et al., 2007). Studies with the use of enzymes in cuniculture are scarce and in many cases results are contradictory.

Enzymes are molecules of protein nature that catalyse chemical reactions in determined conditions of $\mathrm{pH}$ and temperature, making a chemical reaction that is energetically possible, but slow, although it takes lower time than without the presence of the enzyme (Grisham et al., 1999). Enzymes are produced by all the living organisms and many of them participate in the digestion; the enzymes that act on the digestive process can be: 
- Endogenous: produced by the animal in different parts of the digestive tract and in variable quantity depending on the age and the animal species.

- Exogenous: coming from the diet. The enzymes supplemented in the feeds usually have bacterial or mould origin (Biovet, 2008). Once the exogenous enzymes are in the digestive tract are digested like the other proteins. Therefore, they do not leave residues in the faeces or the urine and it is not required a withdrawal period of the animals fed with one or more enzymes (Rojas Méndez, 2011). Consequently, the acceptation is good by the European consumers (Biovet, 2008). Enzymes can be found individually or in cocktails of different enzymes. These enzymes are produced from bacteria or moulds by liquid fermentation and later purified normally in the individual enzyme, that can be sell individually or mixed and market in a cocktail of enzymes. This kind products must be registered as a feed additive in the European Union and requires a high investment of resources by the companies, but on the other hand, it warranties its safety and effect. However, in the market are appearing enzyme complex products that are based on the fermentation of one filamentous mould strain on a solid substrate (corn, DDGS, etc.) producing a wide range of enzymes that have enzymatic activity to improve digestibility in the animals. In addition, it can improve the digestibility of the raw materials used as a substrate and it allows the use of coproducts from the industry, like DDGS. Another advantage of this products is that in the European Union are classified as a raw material and they do not require the extensive registration process like a feed additive.

In some studies, enzymatic supplementation improves mortality, digestibility of some nutrients and / or productive traits (Gutiérrez et al., 2002; Cachaldora et al., 2004; 
Eiben et al., 2004; García-Ruiz et al., 2006; El-Kelawy and El-Shafey, 2017). However, in other studies (Sequeira et al., 2000, García-Palomares et al., 2006; Falcao-e-Cunha et $a l ., 2007)$ no improvements were observed with the addition of enzymes on any of these parameters. On the other hand, the works that study the effect of the dietary enzymatic supplementation on the carcass yield are even scarcer, and with equal disparity of results (Shanmuganathan et al., 2004; Abaza and Omara, 2011; Abd El-Aziz et al. 2019).The lack of clearly positive effects and variability of results could be due that the cecum of the rabbits at 4 weeks of age contents most of the total activity of the pectinases (0.43), amylases (0.45), lactases $(0.57)$, xylanases $(0.65)$, cellulases $(0.69), \beta$-glucosidases $(0.70)$ and ureases $(0.80)$ present in the digestive tract of the rabbit, and these values increase with the age (Marounek et al., 1995). It could be also due to the peculiar digestive physiology of the rabbit, specially the caecotrophy, because is possible to find microbial enzymes along the whole digestive tract (Marounek et al., 1995). These lack of consistency of enzymes could be in addition, partially explain by the different experimental protocols and hygienic conditions (Falcao-e-Cunha et al. 2004).

Anyhow, this would not exclude the interest of enzyme supplementation, but probably, it would restricted to certain phases of the rabbits' life; or the supplementation with only the less digestible feeds, because in this diets is where it can be observed an impairment in carcass yield (Margüenda et al., 2012), performance and nitrogen retention (García et al., 1993). In these cases, the use of exogenous enzymes could improve the nutrient utilization efficacy and retention and in consequence, the productivity. It could allow the use of other kind of raw materials, cheaper and / or that do not compete with the human food, generally of lower quality, and where enzyme supplementation could have similar performance. 
In addition, the concern about the contamination of the soil (eutrophication, accumulation of salts and heavy metals), the water (contamination with nitrates) and the air (contaminant gases, aerosol formation, odours) caused, among others, by the nitrogen produced by the livestock animals is increasing. Even more in some countries of the European Union where it is becoming a reality, with regulations to control the nitrogen (N) production of the farms. For example, the Netherlands and Belgium (Maertens et al., 2005). In fact, there is a European Regulation for the disposal production in the farms (Regulation EC N ${ }^{\circ} 1069 / 2009$ ), that is applied in Spain by the Royal Law 1528/2012, of 8th of November. In rabbits, approximately $2 / 3$ of $N$ ingested is excreted (Carabaño et al., 2009), and therefore, an improved digestibility of the feed could decrease this $\mathrm{N}$ excretion.

\subsection{Usage of other feed additives}

There are certain feed additives that have a positive effect on intestinal health and / or on the animal's immune system, causing better nutrient absorption and better growth. For example, trace elements, the papers that study the effect of the supplementation with trace elements on the DoP are scarce. In this sense, Ebeid et al. (2012), observed an improvement of the DoP with the addition of organic selenium.

Other feed additives, like combinations of herbs, essential oils or probiotics could also have an improvement on carcass yield (Abdel-Wareth et al., 2018; Fathi et al., 2017), under challenge situations. However, results are contradictory and in other works results are not conclusive and have not observed an improvement of the carcass yield (Dalle Zotte et al., 2016; Ayyat et al., 2018) 


\subsection{Chemical composition of the rabbit meat}

Nowadays the rabbit carcasses that are mostly found in the Spanish market come from selected breeds with an average live weight between $2-2.2 \mathrm{~kg}$, which provide very homogeneous carcasses of totally lean meat that has an excellent flavour and texture (Dalle Zote, 2002). The quality of rabbit meat can be assessed by its physical, chemical, and sensorial composition, which are the most valued characteristics by the final consumer, although they are rarely considered by breeders, slaughterhouses and sellers (Xiccato, 1999).

Compared with other domestic species, it has a low content of fat, calories, sodium and a high proportion of protein (Sunki et al., 1978; Ouhayoun et al., 1985) rich in essential amino acids (Hernández and Dalle Zotte, 2010). In addition, the digestibility of its protein is high, with a good biological value (Gilka, 1975; Ouhayoun, 1991b, Hernández and Dalle Zotte, 2010).

Meat is mainly composed of water, protein, and fat, although it also has small amounts of other substances, such as non-protein nitrogen, carbohydrates, and minerals.

In domestic rabbits, the main component of meat is water $(69-73 \%)$, followed by protein (18.5-21\%), including non-protein nitrogenous substances. Fat, along with water, is the meat component that presents the most variations $(6.5-10.5 \%)$; while ashes is the least variable fraction, representing about 1\% (Cobos, 1993). Finally, rabbit meat, like those of other mammals, is a poor source of carbohydrates. The normal glycogen content of mammalian muscle ranges from $0.5-1 \%$ (Price and Schweigert, 1976) in the live animal, but this is a labile component that descends rapidly after a short period of intense muscular activity that accompanies the death of the animal, as well as the irreversible 
anaerobic glycolysis that occurs in the muscle when death occurs and oxygen supply fails (Cobos, 1993).

\subsubsection{Factors that influence the chemical composition}

In the same way as in the carcass yield, the chemical composition depends on several factors that can be intrinsic and extrinsic.

\subsubsection{Intrinsic factors}

\subsection{Age and slaughter weight}

As the animal grows, the chemical composition of the animals undergoes variations (Dalle Zotte, 2002). The percentage of fat in the rabbit carcass changes from an initial phase of rapid decline (up to 5-6 weeks of age) to a second phase of moderate growth (Deltoro and López, 1986).

Most of the authors (Rao et al., 1978; García et al., 1992a, 1993; Saiz, 2016; Saiz et al., 2017) pointed to an increase in fat content and a decrease in the amount of moisture in the meat of rabbits with the weight of the animal.

Therefore, slaughter age and weight have a marked impact on tenderness, fatness and nutritional value of meat and fat (Fernández Martínez, 1993). Young rabbits have meat with a higher percentage of moisture and protein and lower fat. When the reproductive age arrives, its meat is much more tasteless, compact, and greasy. According to Parigi-Bini et al. (1992) for the same breed, age seems to be more important than weight in terms of the variability of the fat content of the carcasses.

If the reproductive age is not reached, the slaughter weight does not seem to affect the ash content of the meat, nor does the protein content vary, and the levels of sodium and cholesterol are still low (Fernández Martínez, 1993). Rao et al. (1978) did not observe 
either changes in the protein content of meat with a greater slaughter weight. However, Ouhayoun et al. (1974) indicated an increase in the protein content of meat with a greater slaughter weight, although the influence of weight is much less than that observed in fat and moisture.

Weaning age has no appreciable effect on the final body composition of rabbits (Rao et al., 1978; Fraga et al., 1983).

\subsection{Breed}

It is another of the factors that most influence the composition of meat. Ciruzzi et al. (1973), obtained higher values of moisture and protein in rabbits of the New Zealand White breed than in Californians, who nevertheless had more fat. The effect of the breed has also been studied by Ouhayoun (1980) and Deltoro et al. (1988b). These authors suggested that the order of precocity for fat deposition in the main breeds used in intensive farms is, from major to minor, Californian, New Zealand, and Flemish Giant.

However, rabbits raised for meat, in practice, are commercial hybrids derived from selection programs based on three crosses, with adult weights between 4 and $5 \mathrm{~kg}$. Its weight at commercial slaughter ages (from 9 to 13 weeks) means that the composition of the carcass in the final product does not show differences (Ouhayoun, 1998). According to previous results (Lambertini et al., 1996; Hernández et al., 1998), the differences between genetic lines in terms of meat quality are negligible and it seems that the composition of rabbit meat is usually quite constant.

\subsubsection{3. $\operatorname{Sex}$}

Fraga et al. (1983) observed that males of the Spanish Giant rabbit contained 1\% more nitrogen and $0.8 \%$ less fat than females of the same breed. Raimondi et al. (1974) 
also observed fatter and less moisture in female meat. Similarly, Deltoro and López (1986) observed that males had a significantly lower fat content in the carcass than females. However, other authors (Costantini and Bosi, 1968; Ciruzzi et al., 1973; Fraga et al., 1978) did not find significant differences due to sex, which seems to be because most rabbits are marketed before reproductive age.

\subsection{Carcass part}

Although the rabbit carcass is quite homogeneous, its chemical composition has slight modifications, depending on the area analysed. Thus, the posterior third of the carcass is richer in moisture and protein and poorer in fat than the front one, while the loin has intermediate values (Ciruzzi et al., 1973; Granat et al., 1977). That is, the parts that have rapid growth are richer in protein and moisture than those of slow growth, confirming the observations made by Abdel-Naby (1979).

\subsubsection{Extrinsic factors}

\subsection{Feeding}

The chemical composition of the feed also influences the chemical composition of the meat, being one of the most important factors (Ouhayoun, 1998; Hernández and Dalle Zotte, 2010).

Fibre has a particularly important role because of its relationship with the digestive transit, together with the energy content and with the DP/DE ratio. When the feeds have a high fibre content cause a decrease in consumption, growth, slaughter weight and carcass yield, but the carcasses usually have a lower fat content (García et al., 1993; Hernández and Dalle Zotte, 2010). In this sense, Fraga et al. (1983) pointed out that an $\mathrm{DE} / \mathrm{DP}$ ratio of 22.8 is the one that provides the lowest fat content and a greater amount 
of body protein in the rabbit. This value is close to that indicated by De Blas et al. (1981) to obtain a maximum growth rate $(23.5 \mathrm{kcal} \mathrm{DE} / \mathrm{g} \mathrm{DP})$. If the DE/DP ratio is increased, the fat content in the carcass tends to increase (Fraga et al., 1983; Dalle Zotte et al., 1997) and significantly reduce the protein, water, and ash content (Pérez, 1978). In other studies, feeds with a different DE/DP ratio during the fattening phase did not modify the carcass characteristics or the chemical composition of the meat (Xiccato et al., 1993). Only when the modifications are extreme in the DE/DP ratio is it when the effect on body composition is detected (Xiccato, 1999).

In addition to an adequate DP/DE ratio, feed must ensure a correct supply of essential amino acids. In rabbits the most limiting are methionine, lysine, and threonine. A deficit in these amino acids has more effect on the productive parameters, than on the carcass characteristics. In fact, DoP and body composition are influenced by the decrease in average daily gain (DWG) and consumption. It has not yet been shown if there is an effect on carcass characteristics when the amount of amino acids is changed without modifying the DWG (Xiccato, 1999). Some studies have shown that methionine supplementation improves DoP and increases the proportion of premium pieces (hind and front legs, loins, and kidneys) (Taboada et al., 1996) and increases the meat / bone ratio (Berchiche et al., 1995).

The addition of fat to the fattening feed implies an increase in the fat content of the carcass (Cobos et al., 1993; Fernández and Fraga, 1996). The same effect has been observed when feeding the rabbits only during the post-weaning (45-55 d of age) with a feed with added fat (Dalle Zotte et al., 1997; Xiccato et al., 1998). 
Feed restriction have also shown some effects the chemical composition of the carcass, like less fat content and increasing of protein content in the restricted animals (Gidenne et al., 2012; Chodová and Tumová, 2013).

\subsection{Environment}

The season of the year has a clear influence on the growth rate of rabbits (Blasco et al., 1983; Ouhayoun, 1984). This effect is indirect, since the environmental temperature influences on the growth rate, through the ingestion of feed. When the temperature increases, the intake decreases (Cervera and Fernández Carmona, 2010). However, in other species a direct effect of the season has also been indicated when the energy metabolism (Close and Stanier, 1984) or the photoperiod is modified (Schanbacher et al., 1982; Tucker et al., 1984). Deltoro et al. (1988a), in California and New Zealand rabbits slaughtered between 1 and 20 weeks of age, observed that only significant differences in the chemical composition of meat appeared in the first three weeks of life (the meat of rabbits born in summer had a lower fat content and higher water and protein) and between 13 and 16 weeks of age (the meat of winter rabbits had higher fat content and lower water and protein). Other researchers (Chiericato et al., 1996) observed a paler meat with a higher proportion of saturated fatty acids at temperatures above thermo neutrality.

\subsection{Measurement of chemical composition}

There are several methods to measure and/or estimate the chemical composition of rabbits. The reference method used is comparative sacrifice, but this method is expensive and avoid following the evolution of body composition over time in the same animal. For this reason, other types of in vivo methods, called indirect ones, have been studied and developed that would prevent animal sacrifice, such as near-infrared spectroscopy (NIRS), especially in breeding rabbits (Masonero et al., 1992), the technique of dilution 
with deuterium oxide (D2O) (Fekete and Brown, 1992), magnetic resonance imaging (MRI) (Szendrö et al., 1992; Köver et al., 1996 and 1998), or Total Body Electrical Conductivity (TOBEC) (Fortun-Lamothe et al., 2002). However, these methods are still expensive in order to be considered as alternative methods to the comparative sacrifice.

The Bioelectric Impedance (BIA) method is another in vivo method of simpler and cheaper application than the previous ones, which has already been evaluated to estimate body composition in other species such as lambs (Berg and Marchello, 1994), calves (Marchello et al., 1992 and 1999), pigs (Swantek et al., 1992, 1999; Marchello et al., 1999), Iberian pigs (Daza et al., 2006) and even in humans (Lukaski et al., 1985a and b). The BIA measures the reduction in voltage that occurs in a body when it is crossed by an alternating current of $425 \mu \mathrm{A}$ intensity and at a frequency of $50 \mathrm{KHz}$. This reduction depends on the conductivity of the body, its geometry, and its volume, in addition to the intensity and frequency of the current. It has been proven that the conductivity of an animal depends on its body composition. Thus, intra and extracellular fluids, electrolytes and minerals act as conductors and comprise a large percentage of lean tissue in the body. The cell membranes behave like capacitors resisting a current until a threshold is reached before allowing the passage of it. The fat acts as an insulator and resists the passage of the applied current. Due to the reduced conductivity of fatty tissue, in comparison to the other compounds of the organism, an animal with a higher fat content has a higher impedance value than an animal with more lean content (Swantek et al., 1999). This is because the current is carried by the body through water and its fluids. In other species it has been described that fat-free tissues have a higher water content, and the electrical signal passes more easily (Marchello and Slanger, 1994).

Recently this technique has already been validated and used with good results to predict in vivo the body reserves of breeding rabbits in different physiological states 
(Nicodemus et al., 2009; Pereda et al. 2010; Rebollar et al., 2011). It has also been used and validated to estimate the body composition of growing rabbits between 25 and $77 \mathrm{~d}$ of age (Saiz et al., 2017) and to estimate the chemical composition of carcasses from 35 to $63 \mathrm{~d}$ old (Saiz, 2016). The interest of using this technique in growing animals is that it allows us to estimate the retention and efficiency utilization of energy and protein. 
OBJETIVES 


\section{OBJECTIVES}

The general objective of this $\mathrm{PhD}$ Thesis was to investigate the capacity of different nutritional strategies (exogenous enzyme supplementation, source and level of ADL and feed restriction) to improve carcass yield, carcass composition and reduce nitrogen excretion in growing rabbits.

The specific objectives of this $\mathrm{PhD}$ Thesis are:

- $\quad$ Study the effect of the supplementation with different doses of a multi-enzyme complex in two types of diets on growth performance, carcass traits, nutrient digestibility and nitrogen and energy balance in growing rabbits.

- Investigate the result of the dietary level and source of lignin on growth performance, carcass traits, nutrient digestibility and nitrogen and energy balance in growing rabbits.

- $\quad$ Research the effect of different feed restriction levels on growth performance, carcass traits, nutrient digestibility and nitrogen and energy balance in growing rabbits. 
MATERIALS AND METHODS 


\section{MATERIALS AND METHODS}

\subsection{Experimental design}

The trials for this PhD were conducted in the Poultry and Rabbit Research Centre (PRC) of Trouw Nutrition R\&D in Toledo (Spain) in collaboration with the Polytechnic University in Madrid (UPM).

All the experimental procedures were approved by the Ethics Committee of Trouw Nutrition R\&D Poultry Research Centre. And the animals were handled in accordance with the Spanish guidelines for experimental animal protection (Spanish Royal Decree 53/2013; BOE, 2013).

In all experiments the rabbit's breed used was New Zealand x Californian, from the maternal line V x paternal line R from UPV, Valencia Spain. Environmental conditions were controlled: $12 \mathrm{~h}$ of light and 12 of darkness, lateral extraction with dynamic ventilation and the temperature ranged between 20 and $24^{\circ} \mathrm{C}$. All cages had one manual feeder and nipple drinking system. All diets were antibiotic free. Feed and water were supplied ad libitum, except in some of the treatments of experiment 4.

The size of the individual cages used in experiments 1,2 and 3 were $25 \times 44 \times 30$ $\mathrm{cm}$. The dimensions of the collective cages in experiments 3 and 4 were $39 \times 100 \times 30$ $\mathrm{cm}$. In the collective cages, 5 rabbits per cage were allocated.

\subsubsection{Experiment 1: Effect of an enzyme complex on the productive performance, slaughter traits and nitrogen and energy balance in growing rabbits.}

A commercial enzymatic complex was supplemented in the feed: 0, 100, 200, 400 and $800 \mathrm{ppm}$ to evaluate the on top effect of different doses in rabbit diets. The enzymatic 
complex used was a coproduct derived from the fermentation on solid state of Aspergillus niger on a solid substrate which have residual enzymatic activity (Table 2).

Table 2. Enzymatic activity of the compound used (according to the producer)

\begin{tabular}{ll} 
Enzyme & Enzymatic activity \\
\hline Amylase & $30 \mathrm{FAU} / \mathrm{g}$ \\
Pentosenase & $100 \mathrm{XU} / \mathrm{g}$ \\
Celulase & $40 \mathrm{CMC} / \mathrm{g}$ \\
Protease & $700 \mathrm{HUT} / \mathrm{g}$ \\
Xilanase & $100 \mathrm{XU} / \mathrm{g}$ \\
Pectinase & $4,000 \mathrm{AJDU} / \mathrm{g}$ \\
$\beta$-glucanase & $200 \mathrm{BGU} / \mathrm{g}$ \\
\hline Alpha-Amylase unit; CMC= Carboxymethyl cellulose; HUT= Hemoglobin Unit \\
\end{tabular}

A total of 225 crossbred mixed-sex rabbits weaned at $34 \mathrm{~d}$ of age, with an average body weight (BW) of $818 \pm 104 \mathrm{~g}$ (mean \pm standard deviation (SD)), were housed in individual cages.

Animals were blocked by litter and randomly assigned to one of the five treatments (45 animals/treatment: Basal feed (B); B+100 ppm of the enzymatic complex; $\mathrm{B}+200$ ppm; $\mathrm{B}+400$ ppm; $\mathrm{B}+800 \mathrm{ppm}$. Feed was formulated following de Blas and Mateos (2010) recommendations (Table 3). Feed and water were supplied ad libitum.

Feed intake and weight of the rabbits was measured in two periods (at weaning (34 d), 48 and 60 d) from 34 to $48 \mathrm{~d}$ and from 49 to $60 \mathrm{~d}$ of age. Daily feed intake, daily weight gain and feed conversion ratio were calculated by period and for the whole fattening cycle. Mortality was recorded daily. 
Table 3. Ingredients and analysed chemical composition of the experimental feed (Experiment 1).

\begin{tabular}{lc}
\hline Ingredients composition, g/kg as fed & Experimental Feed \\
\hline Alfalfa & 250 \\
Barley & 233 \\
Wheat bran & 200 \\
Sunflower meal & 105 \\
Sugar beet pulp & 80.0 \\
Wheat straw & 50.0 \\
Soybean meal & 17.1 \\
Wheat & 15.7 \\
Soybean oil & 15.0 \\
Sepiolite & 13.1 \\
Calcium Carbonate & 10.8 \\
Sodium Chloride & 6.00 \\
Mineral and Vitamin premix* & 3.00 \\
L-Lysine & 1.30 \\
L-Threonine & 0.60 \\
\hline Analysed chemical composition, g/kg DM & \\
\hline Dry matter & 901 \\
Ash & 80.3 \\
Crude Protein & 176 \\
Neutral Detergent Fibre** & 359 \\
Acid Detergent Fibre $* *$ & 215 \\
Acid Detergent Lignin $* *$ & 44.3 \\
Starch (enzymatic) & 174 \\
Ether Extract & 34.2 \\
Gross Energy, kcal/kg DM & 4791 \\
Digestible Energy, kcal/DM*** & 2797 \\
DP/DE*** & 11.0 \\
\hline Trouw Nutiton. Minera and viam compostin & \\
\hline
\end{tabular}

*Provided by Trouw Nutrition. Mineral and vitamin composition (per $\mathrm{kg}$ of complete diet): Calcium: $0.44 \mathrm{~g} / \mathrm{kg}$; Sodium: $0.33 \mathrm{~g} / \mathrm{kg}$; Magnesium (MgO): $0.24 \mathrm{~g}$; Manganese $\left(\mathrm{Mn}_{2} \mathrm{O}_{3}\right): 20$ $\mathrm{mg} / \mathrm{kg}$; Zinc (ZnO): $60 \mathrm{mg} / \mathrm{kg}$; Copper $\left(\mathrm{CuSO}_{4} \cdot 5 \mathrm{H} 2 \mathrm{O}\right): 18 \mathrm{mg} / \mathrm{kg}$; Iodo (KI): $1.10 \mathrm{mg} / \mathrm{kg}$; Cobalt $\left(\mathrm{CoCO} 3 \cdot \mathrm{H}_{2} \mathrm{O}\right): 0.49 \mathrm{mg} / \mathrm{kg}$; Selenium $\left(\mathrm{Na}_{2} \mathrm{SeO}_{3}\right): 0.05 \mathrm{mg} / \mathrm{kg}$; Iron $\left(\mathrm{FeCO}_{3}\right): 78 \mathrm{mg} / \mathrm{kg}$; Vitamin A: 10,000 IU; Vitamin $\mathrm{D}_{3}$ : 1,080 IU; Vitamin E (dl-alfa-tocopherol acetate): $36 \mathrm{IU}$; Vitamin K: $1 \mathrm{mg}$; Vitamin $\mathrm{B}_{1}: 2 \mathrm{mg}$; Vitamin $\mathrm{B}_{2}: 6 \mathrm{mg}$; Vitamin $\mathrm{B}_{6}: 2 \mathrm{mg}$; Vitamin $\mathrm{B}_{12}: 10 \mathrm{mcg} / \mathrm{kg}$; Niacine: $50 \mathrm{mg}$; Calcium pantothenate: $20 \mathrm{mg}$; Pantothenic acid: $18.40 \mathrm{mg}$; Folic acid: $5 \mathrm{mg}$; Biotin: 60 mcg; Choline chloride: $260 \mathrm{mg}$; Sepiolite: $0.38 \mathrm{~g}$; Butylhydroxyanisol: $0.12 \mathrm{mg}$; Butylhydroxytoluene: $1.32 \mathrm{mg}$; Etoxiquine: $0.19 \mathrm{mg}$; Diclazuril $0.5 \mathrm{~g} / 100 \mathrm{~g}$ (Clinacox $0.5 \%$ Premix $\left.{ }^{\circledR}\right): 1 \mathrm{mg}$. ** Values corrected for ash. $* * *$ Determined in vivo by a digestibility trial.

\subsubsection{Experiment 2: Effect of an enzyme complex in a protein and energy reduced diet on productive performance, slaughter traits and nitrogen and energy balance in growing rabbits.}

The target of this second trial was to evaluate the capacity of the same enzyme complex to compensate a reduction in digestible protein (DP) and energy (DE). 
Therefore, two experimental feeds were formulated to differ in their protein (176 vs. 158 g DP/kg DM) and energy (2797 vs. $2585 \mathrm{kcal} \mathrm{DE} / \mathrm{kg} \mathrm{DM})$. Control feed was the same than in the previous trial. Each feed was supplemented with three different doses of the enzymatic complex: 0, 100 and 200 ppm.

A total of 270 crossbred mixed-sex rabbits weaned at $34 \mathrm{~d}$ of age, with a weaning $\mathrm{BW}$ of $808 \pm 107 \mathrm{~g}$ (mean $\pm \mathrm{SD})$, were randomly allocated to the different treatments and housed in individual cages.

Animals were blocked by litter and randomly assigned to one of the six treatments (36 animals/treatment: $\operatorname{diet} \mathrm{A}+0$ ppm enzymatic supplementation; diet $\mathrm{A}+100 \mathrm{ppm}$; diet A +200 ppm; diet B +0 ppm; diet B +100 ppm and diet B +200 ppm). Control diet, diet A, was formulated following de Blas and Mateos (2010) recommendations (2797 kcal DE/kg DM; 176 g CP/kg DM and 359 g NDF/kg DM). Diet B was formulated to have lower DP and DE and higher NDF (2585 kcal DE/kg DM; $158 \mathrm{~g} \mathrm{CP} / \mathrm{kg} \mathrm{DM}$ and $374 \mathrm{~g}$ NDF/kg DM; Table 4).

Feed intake and weight of the rabbits was measured in two periods (at weaning (34 d), 48 and $60 \mathrm{~d}$ ) from 34 to $48 \mathrm{~d}$ and from 49 to $60 \mathrm{~d}$ of age. Daily feed intake, daily weight gain and feed conversion were calculated by period and for the whole fattening cycle. Mortality was recorded daily. 
Table 4. Ingredients and analysed chemical composition of the experimental feeds (Experiment 2).

\begin{tabular}{lcc}
\hline Ingredients composition, g/kg as fed & Diet A & Diet B \\
\hline Alfalfa & 250 & 181 \\
Barley & 233 & 146 \\
Wheat bran & 200 & 108 \\
Sunflower meal & 105 & 130 \\
Sugar beet pulp & 80.0 & 73.8 \\
Wheat straw & 50.0 & 150 \\
Soybean meal & 17.1 & 6.90 \\
Wheat & 15.7 & 145 \\
Soybean oil & 15.0 & 15.0 \\
Sepiolite & 13.1 & 20.0 \\
Calcium Carbonate & 10.8 & 13.1 \\
Sodium Chloride & 6.00 & 6.00 \\
Mineral and Vitamin premix* & 3.00 & 3.00 \\
L-Lysine & 1.30 & 2.00 \\
L-Threonine & 0.60 & 0.70 \\
\hline Analysed chemical composition, g/kg DM & \\
\hline Dry matter & 901 & 909 \\
Ash & 80.3 & 86.3 \\
Crude Protein & 176 & 158 \\
Neutral Detergent Fibre** & 359 & 374 \\
Acid Detergent Fibre ** & 215 & 224 \\
Acid Detergent Lignin** & 44.3 & 45.8 \\
Starch (enzymatic) & 174 & 175 \\
Ether Extract & 34.2 & 30.0 \\
Gross Energy, kcal/kg DM & 4791 & 4672 \\
Digestible Energy, kcal/DM*** & 2797 & 2585 \\
DP/DE*** & 11.0 & 10.9 \\
\hline Trouw Nution. Minera $*$ (n) & & \\
\hline
\end{tabular}

*Provided by Trouw Nutrition. Mineral and vitamin composition (per $\mathrm{kg}$ of complete diet): Calcium: $0.44 \mathrm{~g} / \mathrm{kg}$; Sodium: $0.33 \mathrm{~g} / \mathrm{kg}$; Magnesium $(\mathrm{MgO}): 0.24 \mathrm{~g}$; Manganese $\left(\mathrm{Mn}_{2} \mathrm{O}_{3}\right): 20$ $\mathrm{mg} / \mathrm{kg}$; Zinc (ZnO): $60 \mathrm{mg} / \mathrm{kg}$; Copper $\left(\mathrm{CuSO}_{4} \cdot 5 \mathrm{H}_{2} \mathrm{O}\right): 18 \mathrm{mg} / \mathrm{kg}$; Iodo (KI): $1.10 \mathrm{mg} / \mathrm{kg}$; Cobalt $\left(\mathrm{CoCO}_{3} \cdot \mathrm{H}_{2} \mathrm{O}\right): 0.49 \mathrm{mg} / \mathrm{kg}$; Selenium $\left(\mathrm{Na}_{2} \mathrm{SeO}_{3}\right): 0.05 \mathrm{mg} / \mathrm{kg}$; Iron $\left(\mathrm{FeCO}_{3}\right): 78 \mathrm{mg} / \mathrm{kg}$; Vitamin A: 10,000 IU; Vitamin $\mathrm{D}_{3}$ : 1,080 IU; Vitamin E (dl-alfa-tocopherol acetate): $36 \mathrm{IU}$; Vitamin K: $1 \mathrm{mg}$; Vitamin $\mathrm{B}_{1}: 2 \mathrm{mg}$; Vitamin $\mathrm{B}_{2}: 6 \mathrm{mg}$; Vitamin $\mathrm{B}_{6}: 2 \mathrm{mg}$; Vitamin $\mathrm{B}_{12}: 10 \mathrm{mcg} / \mathrm{kg}$; Niacine: $50 \mathrm{mg}$; Calcium pantothenate: $20 \mathrm{mg}$; Pantothenic acid: $18.40 \mathrm{mg}$; Folic acid: $5 \mathrm{mg}$; Biotin: 60 mcg; Choline chloride: $260 \mathrm{mg}$; Sepiolite: $0.38 \mathrm{~g}$; Butylhydroxyanisol: $0.12 \mathrm{mg}$; Butylhydroxytoluene: $1.32 \mathrm{mg}$; Etoxiquine: $0.19 \mathrm{mg}$; Diclazuril $0.5 \mathrm{~g} / 100 \mathrm{~g}$ (Clinacox $0.5 \%$ Premix $\left.{ }^{\circledR}\right): 1 \mathrm{mg}$. ** Values corrected for ash. $* * *$ Determined in vivo by a digestibility trial. 


\subsubsection{Experiment 3: Effect of different lignin levels and sources on productive performance, slaughter traits and nitrogen and energy balance in growing rabbits.}

For the aim of this trial, five different treatments in a $3 \times 2$ factorial arrangement, with three different levels of acid detergent lignin (4.5, 5.5 and 6.5\% DM) and two sources of lignin (Arbocel® or defatted grape seed meal) were used.

A total of 936 crossbred mixed-sex rabbits were used. Of all of them, 216 were weaned at $34 \mathrm{~d}$, BW of $915 \pm 85 \mathrm{~g}$ (mean $\pm \mathrm{SD}$ ) and housed in individual cages until the $60 \mathrm{~d}$ of age. The remaining 720 animals were weaned at $35 \mathrm{~d}$ of age, BW of $808 \pm 107 \mathrm{~g}$ $($ mean \pm SD) and housed in collective cages until $61 \mathrm{~d}$.

Diets were formulated to have same energy (2886 $\pm 47 \mathrm{kcal} \mathrm{DE} / \mathrm{kg} \mathrm{DM})$, protein $(179 \pm 3 \mathrm{~g} \mathrm{CP} / \mathrm{kg} \mathrm{DM})$ and fibre $(367 \pm 10 \mathrm{~g} \mathrm{NDF} / \mathrm{kg} \mathrm{DM})$ levels differing in lignin content $(3.5,4.5$ and 5.5\%) and lignin source. Feeds were formulated following de Blas and Mateos (2010) recommendations. Feed and water were supplied ad libitum.

Animals were blocked by litter and randomly assigned to one of the five diets (36 animals/treatment: low lignin and defatted grape seed meal (LG); low lignin and Arbocel ${ }^{\circledR}(\mathrm{LA})$; medium lignin and defatted grape seed meal (MG); medium lignin and Arbocel® (MA); high lignin and defatted grape seed meal (HG); high lignin and Arbocel® (HA).

Tables 5 and 6 show the chemical composition of the different lignin sources used. Whereas in Table 7 is shown the feeds ingredients and chemical composition.

In the individually housed rabbits, feed intake and weight of the rabbits was measured in two periods (at weaning (34 d), 48 and $60 \mathrm{~d}$ ) from 34 to $48 \mathrm{~d}$ and from 49 to 
$60 \mathrm{~d}$ of age. In the rabbits housed collectively, weight and feed intake were measured at the beginning ( $35 \mathrm{~d})$ and at the end $(61 \mathrm{~d})$ of the fattening period, in only one period from 35 to $61 \mathrm{~d}$ of age. Daily feed intake, daily weight gain and feed conversion ratio were calculated by period and for the whole fattening cycle. Mortality was recorded daily.

Table 5. Chemical composition of the defatted grape seed meal, comparison of different analyses (Experiment 3).

\begin{tabular}{lcccc}
\hline & García et al. (2002) & Gidenne (2003) & Own Analysis & $\begin{array}{c}\text { FEDNA } \\
(\mathbf{2 0 1 9}) *\end{array}$ \\
\hline Chemical composition: & & & & \\
Dry matter & 90.0 & - & 86.0 & 91.8 \\
Ash & 5.84 & - & 3.07 & 2.90 \\
Ether Extract & 3.60 & 73 & 1.40 & 11.1 \\
Neutral Detergent Fibre & 80.6 & 65 & 65.2 & 67.0 \\
Acid Detergent Fibre & 72.0 & 55 & 57.1 & 57.0 \\
Acid Detergent Lignin & 59.0 & - & 44.8 & 42.9 \\
Acid Detergent Cutin & 46.0 & 44.1 & - & - \\
Crude Fibre & 46.3 & 9.9 & 92.8 & 41.4 \\
Crude Protein & 11.0 & - & 9.98 & 9.30 \\
Insoluble Pectines in water & - & - & - & - \\
Gross Energy, kcal/kg DM & 4899 & & - & - \\
\hline
\end{tabular}

* Non-Defatted Grape Pips.

Table 6. Chemical composition of Arbocel ${ }^{\circledR}(\%)$, comparison of different analysis (Experiment 3).

\begin{tabular}{lcc}
\hline & Colin et al. (2007) & Own Analysis \\
\hline Protein & 0.80 & - \\
Ether Extract & 0.10 & - \\
Crude Fibre & 67.6 & 69.4 \\
Crude Ashes & 0.30 & - \\
Starch & 0.00 & - \\
Neutral Detergent Fibre & 84.8 & 86.6 \\
Acid Detergent Fibre & 70.8 & 73.2 \\
Acid Detergent Lignin & 23.9 & 27.7 \\
\hline
\end{tabular}


Table 7. Ingredients and analysed chemical composition of the experimental feeds (Experiment 3).

\begin{tabular}{|c|c|c|c|c|c|}
\hline Ingredients composition, $\mathrm{g} / \mathrm{kg}$ as fed & LG \& LA & MG & $\mathrm{HG}$ & MA & HA \\
\hline Wheat bran & 320 & 320 & 320 & 276 & 265 \\
\hline Alfalfa & 306 & 313 & 320 & 320 & 285 \\
\hline Wheat & 150 & 150 & 150 & 150 & 151 \\
\hline Sunflower meal & 62.4 & 79.3 & 96.2 & 124 & 89.6 \\
\hline Wheat straw & 60.0 & 30.0 & - & 38.7 & - \\
\hline Soybean meal & 47.4 & 28.5 & 9.60 & 11.5 & 57.8 \\
\hline Soybean oil & 21.0 & 21.6 & 22.2 & 22.1 & 24.9 \\
\hline Sepiolite & 16.8 & 18.4 & 20.0 & 20.0 & 20.0 \\
\hline Salt & 6.00 & 6.00 & 6.00 & 6.00 & 6.00 \\
\hline Calcium Carbonate & 4.40 & 6.20 & 8.00 & 7.00 & 8.00 \\
\hline Mineral and Vitamin premix* & 3.00 & 3.00 & 3.00 & 3.00 & 3.00 \\
\hline Monocalcium Phosphate & 1.70 & 2.40 & 3.00 & 0.60 & 6.00 \\
\hline L-Lysine, monohydrochloride & 0.50 & 0.80 & 1.20 & 1.20 & 0.20 \\
\hline L-Treonine & 0.40 & 0.50 & 0.70 & 0.60 & 0.30 \\
\hline Arbocel $^{\circledR}$ & - & - & - & 20.0 & 83.0 \\
\hline Defatted grape seeds meal & - & 20.1 & 40.2 & - & - \\
\hline \multicolumn{6}{|c|}{ Analysed chemical composition, g/kg DM } \\
\hline Dry matter, $\mathrm{g} / \mathrm{kg}$ & 890 & 889 & 895 & 898 & 897 \\
\hline Ash & 99.9 & 102 & 104 & 104 & 102 \\
\hline Crude Protein & 184 & 179 & 176 & 177 & 181 \\
\hline Neutral Detergent Fibre** & 364 & 362 & 354 & 378 & 377 \\
\hline Acid Detergent Fibre** & 213 & 218 & 220 & 238 & 238 \\
\hline Acid Detergent Lignin** & 47.8 & 60.3 & 67.2 & 58.7 & 62.3 \\
\hline Starch (enzymatic) & 155 & 156 & 159 & 151 & 145 \\
\hline Ether Extract & 34.0 & 40.5 & 40.5 & 38.5 & 40.5 \\
\hline Gross Energy, kcal/kg & 4873 & 4920 & 4875 & 4848 & 4873 \\
\hline Digestible Energy, $\mathrm{kcal} / \mathrm{kg} * * *$ & 2939 & 2909 & 2908 & 2825 & 2848 \\
\hline $\mathrm{DP} / \mathrm{DE} * * *$ & 10.9 & 10.6 & 10.2 & 10.5 & 11.0 \\
\hline Hemicellulose (NDF - ADL) & 13.4 & 12.7 & 12.0 & 12.5 & 12.5 \\
\hline Cellulose (ADF - ADL) & 13.4 & 12.8 & 12.3 & 14.6 & 14.4 \\
\hline Ratio ADL/Cellulose & 0.32 & 0.42 & 0.49 & 0.36 & 0.39 \\
\hline
\end{tabular}

LA: Low dose of Arbocel; LG: Low dose of defatted grape seed meal; MA: Medium dose of Arbocel; MG: Medium dose of defatted grape seed meal; HA: High dose Arbocel; HG: High dose defatted grape seed meal.

* Provided by Trouw Nutrition España (Tres Cantos, Spain). Mineral and vitamin composition (per kg of final feed): Calcium: $0.44 \mathrm{~g}$; Sodium: 0.33g; Magnesium (MgO): $0.24 \mathrm{~g}$; Manganese $\left(\mathrm{Mn}_{2} \mathrm{O}_{3}\right): 20 \mathrm{mg}$; Zinc ( $\left.\mathrm{ZnO}\right): 60 \mathrm{mg}$; Copper $\left(\mathrm{CuSO}_{4} \cdot 5 \mathrm{H}_{2} \mathrm{O}\right): 18 \mathrm{mg}$; Iodo (KI): $1.10 \mathrm{mg}$; Cobalt $\left(\mathrm{CoCO}_{3} \cdot \mathrm{H}_{2} \mathrm{O}\right): 0.49 \mathrm{mg}$; Selenium $\left(\mathrm{Na}_{2} \mathrm{SeO}_{3}\right): 0.05 \mathrm{mg}$; Iron $\left(\mathrm{FeCO}_{3}\right): 78 \mathrm{mg}$; Vitamin A: 10,000 IU; Vitamin $\mathrm{D}_{3}$ : $1080 \mathrm{IU}$; Vitamin E (dl-alfa-tocopherol acetate): $36 \mathrm{IU}$; Vitamin K: $1 \mathrm{mg}$; Vitamin $B_{1}: 2 \mathrm{mg}$; Vitamin $B_{2}: 6 \mathrm{mg}$; Vitamin $B_{6}: 2 \mathrm{mg}$; Vitamin $B_{12}: 12 \mathrm{mcg}$; Niacine: $50 \mathrm{mg}$; Calcium pantothenate: $20 \mathrm{mg}$, Pantothenic acid: $18.4 \mathrm{mg}$; Folic acid: $5 \mathrm{~g}$; Biotine: $60 \mathrm{mcg}$; Choline Chloride: $260 \mathrm{mg}$; Sepiolite: 0.38; Butodroxianisol: $0.12 \mathrm{mg}$; Butohidroxitolueno: 1.32 $\mathrm{mg}$; Etoxiquine: $0.19 \mathrm{mg}$; Diclazuril $0.5 \mathrm{~g} / 100 \mathrm{~g}$ (Clinacox 0.5\% Premix@): $1 \mathrm{mg}$. ** Values corrected for ash. ${ }^{* * *}$ Determined in vivo by a digestibility trial. 


\subsubsection{Experiment 4: Effect of feed restriction on growth performance, carcass yield and nitrogen and energy balance in growing rabbits.}

A total of 600 rabbits, weaned at $34 \mathrm{~d}$ weighing $660 \pm 64.3 \mathrm{~g}$ (mean $\pm \mathrm{SD}$ ), were assigned at random to the five experimental treatments (120 rabbits/treatment, resulting 24 replicates per treatment). Each treatment was applied with different levels of feed restriction. In the control group rabbits were fed ad libitum during the whole fattening period (34-61 d of age). In the other four treatments, the animals were restricted by 80 or $70 \%$ of the theoretical ad libitum consumption during the whole fattening period (R80 and $\mathrm{R} 70$ respectively), or restricted by 80 or $70 \%$ only until the 48 th $\mathrm{d}$ of life and then fed ad libitum until $61 \mathrm{~d}$ of age (R80AL and R70AL, respectively).

All rabbits received the same feed without antibiotics $(2,450 \mathrm{kcal} \mathrm{DE} / \mathrm{kg} ; 16 \% \mathrm{CP}$ and $34 \%$ NDF; Table 8) during the whole experimental period. Feed intake and weight of the rabbits were measured in two periods, from 34 to $48 \mathrm{~d}$ and from 49 to $61 \mathrm{~d}$ of age. The feed conversion ratio (FCR) was calculated as well as for these two periods. Mortality was recorded daily. 
Table 8. Ingredients and analysed chemical composition of the experimental feed (Experiment 4).

\begin{tabular}{lc}
\hline Ingredients composition, g/kg as fed & Experimental feed \\
\hline Wheat bran & 237 \\
Barley & 226 \\
Alfalfa & 192 \\
Wheat straw & 107 \\
Sunflower meal & 98.3 \\
Soybean meal & 45.8 \\
Sugar beet pulp & 39.4 \\
Soybean oil & 16.5 \\
Sepiolite & 13.4 \\
Calcium Carbonate & 13.1 \\
Sodium Chloride & 6.00 \\
Mineral and vitamin premix* & 3.00 \\
Monocalcium phosphate & 1.70 \\
L-Lysine & 0.60 \\
DL-Methionine & 0.20 \\
\hline Analysed chemical composition, g/kg DM & \\
\hline Dry matter, g/kg & 911 \\
Ash & 96.8 \\
Crude protein & 159 \\
Neutral Detergent Fibre** & 324 \\
Acid Detergent Fibre** & 189 \\
Acid Detergent Lignin** & 44.0 \\
Starch (enzymatic) & 131 \\
Ether extract & 30.0 \\
Gross Energy (GE), kcal/kg DM & 4668 \\
Digestible Energy, kcal/kg DM*** & 2754 \\
\hline
\end{tabular}

* Provided by Trouw Nutrition España (Tres Cantos, Spain). Mineral and vitamin composition (per kg of final feed): Calcium: $0.44 \mathrm{~g}$; Sodium: 0.33g; Magnesium (MgO): $0.24 \mathrm{~g}$; Manganese $\left(\mathrm{Mn}_{2} \mathrm{O}_{3}\right): 20 \mathrm{mg}$; Zinc $(\mathrm{ZnO}): 60 \mathrm{mg}$; Copper $\left(\mathrm{CuSO}_{4} \cdot 5 \mathrm{H}_{2} \mathrm{O}\right): 18 \mathrm{mg}$; Iodo $(\mathrm{KI}): 1.10$ $\mathrm{mg}$; Cobalt $\left(\mathrm{CoCO}_{3} \cdot \mathrm{H}_{2} \mathrm{O}\right)$ : $0.49 \mathrm{mg}$; Selenium $\left(\mathrm{Na}_{2} \mathrm{SeO}_{3}\right): 0.05 \mathrm{mg}$; Iron $\left(\mathrm{FeCO}_{3}\right): 78 \mathrm{mg}$; Vitamin A: 10,000 IU; Vitamin $\mathrm{D}_{3}$ : $1080 \mathrm{IU}$; Vitamin E (dl-alfa-tocopherol acetate): 36 IU; Vitamin K: $1 \mathrm{mg}$; Vitamin $\mathrm{B}_{1}: 2 \mathrm{mg}$; Vitamin $\mathrm{B}_{2}: 6 \mathrm{mg}$; Vitamin $\mathrm{B}_{6}: 2 \mathrm{mg}$; Vitamin $\mathrm{B}_{12}: 12 \mathrm{mcg}$; Niacine: $50 \mathrm{mg}$; Calcium pantothenate: $20 \mathrm{mg}$, Pantothenic acid: $18.4 \mathrm{mg}$; Folic acid: $5 \mathrm{~g}$; Biotine: $60 \mathrm{mcg}$; Choline Chloride: $260 \mathrm{mg}$; Sepiolite: 0.38; Butodroxianisol: $0.12 \mathrm{mg}$; Butohidroxitolueno: $1.32 \mathrm{mg}$; Etoxiquine: $0.19 \mathrm{mg}$; Diclazuril $0.5 \mathrm{~g} / 100 \mathrm{~g}$ (Clinacox 0.5\% Premix(): $1 \mathrm{mg}$.

** Values corrected for ash. *** Determined in vivo by a digestibility trial.

\subsection{Apparent total-tract digestibility}

The apparent total-tract digestibility (ATTD) of dry matter (DM), organic matter $(\mathrm{OM})$, gross energy $(\mathrm{GE})$, crude protein $(\mathrm{CP})$, neutral detergent fibre (NDF) and ether extract (EE) were determined following the indications of the European Reference Method (Perez et al., 1995). Feed intake and faeces were recorded from 53 to $57 \mathrm{~d}$ of age. 
In experiments 1, 2 and 3 digestibility analysis were done in 11 rabbits per treatment. While in experiment 4 were used 12 rabbits per treatment. In Experiment 4, at $53 \mathrm{~d}$ of age, 60 animals were transferred to another facility, with same environmental conditions, and randomly housed in the individual cages. Transfer was done on day 50 to have an adaptation period of three $d$. The rest of experiments were housed already in the individual cages for the digestibility trial during the whole fattening period.

\subsection{Slaughter traits}

In order to evaluate the slaughter traits, at the end of each trial, $62 \mathrm{~d}$ of age, 24 animals per treatment were selected based on average body weight, and without fasting. Average body weight in each experiment were: $2355 \pm 93 ; 2616 \pm 86 ; 2316 \pm 112 ; 1993$ \pm 155 g, respectively.

Rabbits were electrically stunned and immediately slaughtered and bled from 8:00 to $12: 00 \mathrm{~h}$ (according to the requirements of the European Convention for the Protection of Vertebrate Animals used for Experimental and Other Scientific Purposes, (Directive 2010/63/EU). After that, skin, genitals, urinary bladder, gastrointestinal tract, and the distal part of the legs were removed. Body weight before the slaughter (BWS) was recorded and the carcass were weighted after cooled at $5{ }^{\circ} \mathrm{C}-10^{\circ} \mathrm{C}(\mathrm{CCW})$, including the head, liver, kidneys and the organs located in the thorax and neck (lungs, oesophagus, trachea, thymus and heart). The full gastrointestinal tract (included the stomach, caecum and intestinal content and the urogenital tract with the empty urinary bladder), liver (excluding gall bladder), and the full and empty stomach, and full caecum were also weighted. The carcass assessment was done according to the recommendations of Blasco and Ouhayoun (1993). The dressing out percentage was calculated as: CCW*100/BWS. 


\subsection{Carcass chemical composition and nitrogen and energy balances}

In vivo whole body and carcass chemical composition (water, protein, ash and fat) and energy content were estimated by the bioelectric impedance method (BIA) in 15 animals/treatment using the multiple regression equations developed by Saiz (2016) and Saiz et al. (2017). Resistance and reactance were measured in rabbits with a body composition analyzer (Model Quantum II, RJL 149 Systems, Detroit, MI, USA) always in the same animal. Measures were taken twice per animal at 34 and $60 \mathrm{~d}$ of age and at 34 and $61 \mathrm{~d}$ in Experiment 4. Animals were blocked by litter.

Carcass nitrogen and energy content estimated by BIA method and the ATTD were used to obtain the nitrogen and energy retention in the carcass (NR carcass and ER carcass, respectively) between 34 and $60 \mathrm{~d}$ of age in 11 rabbits/treatments except in Experiment 4 that was estimated between 34 and $61 \mathrm{~d}$ of age in 12 animals/treatment. In the same way, estimated values for the total body nitrogen and energy content were used to obtain the nitrogen and energy retention in the whole body (NR whole body and ER whole body, respectively) at 34 and $60 \mathrm{~d}$ of age or 34 and $61 \mathrm{~d}$ in Experiment 4 . Values were expressed per $\mathrm{kg} \mathrm{BW}^{0.75}$ and $\mathrm{d}(\mathrm{BW}$ was calculated as the average of the final and the initial BW).

Moreover, nitrogen and GE intake ( $\mathrm{Ni}$ and $\mathrm{GEi}$, respectively) and digestible nitrogen and energy intake (DNi and DEi, respectively) were recorded to calculate the overall $\mathrm{N}$ and GE carcass retention efficiency as: NR carcass/DNi and ER carcass/DEi, both expressed as $\%$. The overall $\mathrm{N}$ and GE in whole body retention efficiency were estimated as: NR whole body/DNi and ER whole body/DEi, both expressed as \%.

Total $\mathrm{N}$ and GE losses as skin and viscera, faeces or heat production and urine were calculated as follows: 
- $\quad \mathrm{N}$ lost as skin and viscera $\left(\mathrm{g} / \mathrm{kg} \mathrm{BW}^{0.75}\right.$ and $\left.\mathrm{d}\right)=(\mathrm{g} \mathrm{NR}$ whole body $-\mathrm{g} \mathrm{NR}$ carcass) $/ \mathrm{kg} \mathrm{BW}^{0.75}$ and $\mathrm{d}$.

- $\quad \mathrm{N}$ excreted as faeces $\left(\mathrm{g} / \mathrm{kg} \mathrm{BW} \mathrm{BW}^{0.75}\right.$ and $\left.\mathrm{d}\right)=(\mathrm{Ni}-\mathrm{DNi}) / \mathrm{kg} \mathrm{BW}^{0.75}$ and $\mathrm{d}$.

- $\quad \mathrm{N}$ excreted as urine $\left(\mathrm{g} / \mathrm{kg} \mathrm{BW} \mathrm{BW}^{0.75}\right.$ and $\left.\mathrm{d}\right)=(\mathrm{DNi}-\mathrm{NR}$ whole body $) / \mathrm{kg} \mathrm{BW}^{0.75}$ and d.

- $\quad$ Energy lost as skin and viscera $\left(\mathrm{MJ} / \mathrm{kg} \mathrm{BW}^{0.75}\right.$ and d $)=(\mathrm{MJ}$ ER whole body MJ ER carcass $) / \mathrm{kg} \mathrm{BW}^{0.75}$ and d.

- $\quad$ Energy excreted as faeces $\left(\mathrm{MJ} / \mathrm{kg} \mathrm{BW}^{0.75}\right.$ and d $)=(\mathrm{GEi}-\mathrm{DEi}) / \mathrm{kg} \mathrm{BW}^{0.75} \cdot \mathrm{d}$.

- $\quad$ Energy lost as urine and heat production $\left(\mathrm{MJ} / \mathrm{kg} \mathrm{BW}^{0.75}\right.$ and d $)=(\mathrm{DEi}-\mathrm{ER}$ whole body $/ \mathrm{kg} \mathrm{BW}^{0.75}$ and $\mathrm{d}$.

\subsection{Chemical analysis}

All chemical analysis, both feed and faeces, were done twice. Procedures of the AOAC (2005) were used to determine DM (method 934.01), ash (method 942.05), CP (method 968.06 N x 6.25; FP-528 LECO®, St. Joseph, MI, USA), ether extract (method 920.39) and starch amyloglucosidase- $\alpha$-amylase method; method 996.11). Dietary NDF was determined using the filter bag system (Ankom Technology, New York) according to Maertens et al. (2002), and a thermo-stable amylase without any sodium sulphite added. It was corrected for its own ash. Dietary acid detergent fibre and acid detergent lignin were analyzed according to Goering and Van Soest (1970). Gross energy was measured by adiabatic bomb calorimeter (Model 6100, Parr Instrument Company, Moline, IL, USA).

\subsection{Statistical analysis}

In Experiment 1 growth traits, digestibility, slaughter traits, chemical body and carcass composition and nitrogen and energy balance were analysed using a covariance 
analysis studying the linear and quadratic effects of the dose by including it as a covariate. The experimental unit was the cage. Initial weight at weaning $(34 \mathrm{~d})$ was used as a covariable for the growth traits, slaughter traits and slaughter weight. Carcass chemical composition at $34 \mathrm{~d}$ was used as a covariate of each constituent for the analysis of the carcass chemical composition at the end of each experiment. Statistical analyses were done using the GLM procedure of SAS vs 9.2 (SAS Institute Inc., 2002).

In Experiment 2 productive performance, body and carcass chemical composition and slaughter traits were analysed as a randomized $3 \times 2$ factorial model. Whereas digestibility and nitrogen and energy balance were analysed using a 2x2 factorial model (two diets $\mathrm{x}$ two doses $(0$ and $200 \mathrm{ppm})$ ). The experimental unit was the cage. Initial weight at weaning ( $34 \mathrm{~d}$ ) was used as a covariate for the growth traits, slaughter traits and slaughter weight, and carcass chemical composition at $34 \mathrm{~d}$ was used as a covariate of each constituent for the analysis of the carcass chemical composition at the end of each experiment. Statistical analyses were done using the GLM procedure of SAS vs 9.2 (SAS Institute Inc., 2002). A Tukey test was used for means comparisons.

In Experiment 3 all parameters and results were analysed as a randomized $3 \times 2$ model. The experimental unit was the cage. Initial weight at weaning (34 d) was used as a covariate for the growth traits, slaughter traits and slaughter weight, and carcass chemical composition at $34 \mathrm{~d}$ was used as a covariable of each constituent for the analysis of the carcass chemical composition at the end of each experiment. Statistical analyses were done using the GLM procedure of SAS vs 9.2 (SAS Institute Inc., 2002). A Tukey test was used for means comparisons. Mortality of collective cages were analysed using a Poisson model, with the GENMOD procedure and considering a Poisson distribution. 
In Experiment 4, growth traits in the whole fattening period, digestibility, slaughter traits and chemical body and carcass composition were analysed as a randomized model, with the level of feed restriction as main effect of variation. Growth traits were analysed as a repeated measurement model considering the phase of fattening (34-48 $\mathrm{d}$ and $48-61 \mathrm{~d}$ ) as time effect, the treatment, the interaction treatment $\times$ phase of fattening, and the weaning weight as a covariate. We compared four different model structures (compound symmetry and auto-regressive order one, both considering homo and heterogeneous variances). The best fit (considering BIC or AIC) was for a compound symmetry and heterogeneous variance. Growth traits were also analysed as a factorial arrangement (excluding control group) phase of fattening $\times$ treatment. The experimental unit for growth traits was the cage. For the analysis of the chemical composition, the initial value (at $34 \mathrm{~d}$ ) of each constituent was used as a covariate. Statistical analyses were done using the MIXED procedure of SAS vs 9.2 (SAS Institute Inc., 2002). A Tukey test was used for means comparisons because of the interest to compare control diet with the different restriction strategies and the latter among them. 
RESULTS 


\section{RESULTS}

\subsection{Experiment 1: Effect of an enzyme complex on the productive performance, slaughter traits and nitrogen and energy balance in growing rabbits.}

\subsubsection{Growth performance}

During the first fattening phase (34 to $48 \mathrm{~d}$ of live), the enzymatic supplementation improved linearly $(\mathrm{P}<0.05)$ the feed conversion ratio $(\mathrm{FCR})$, without affecting the average daily feed intake (ADFI) neither the average daily weight gain (DWG) (Table 9).

In the second phase (from 49 to $60 \mathrm{~d}$ ), there was a quadratic variation for both FCR and DWG $(\mathrm{P}<0.05)$ with an optimal dose in both parameters of $400 \mathrm{ppm}$.

However, during the whole fattening phase these effects are lost or diluted, as only a quadratic tendency in FCR was observed, being numerically optimal for $400 \mathrm{ppm}$. Mortality was extremely low (1.77\%). Only two rabbits from treatment B and another two from $\mathrm{B}+200 \mathrm{ppm}$ died in whole fattening period.

\subsubsection{Slaughter traits}

Enzymes did not affect carcass yield (57.8 \% on average; Table 10). There was only a significant effect $(\mathrm{P}<0.05)$ in the digestive tract weight, relative to the live weight of the animal, that increased linearly with the enzyme supplementation.

\subsubsection{Apparent total-tract digestibility (ATTD)}

Dry matter, organic matter, gross energy, and ether extract digestibility decreased linearly $(\mathrm{P}<0.05)$ with the multienzyme complex inclusion (Table 11). However, dry 
matter intake, crude protein, and neutral detergent fibre digestibility were not affected by the enzyme supplementation $(\mathrm{P}>0.05)$.

\subsubsection{Carcass chemical composition and nitrogen and energy balances}

Carcass chemical composition was not affected by the enzymatic complex supplementation (Table 12).

Any of the parameters evaluated for the nitrogen balance were affected $(\mathrm{P}>0.05)$ by the treatments (Table 13), except energy balance that showed a significant $(\mathrm{P}<0.05)$ linear decrease on digestible energy intake and an increase in the energy excreted in the faeces. 
Table 9. Effect of enzyme dose supplementation (100, 200, 400 and $800 \mathrm{ppm})$ on zootechnical parameters in rabbits from 34 to $60 \mathrm{~d}$ of age. (Experiment 1).

\begin{tabular}{|c|c|c|c|c|c|c|c|c|}
\hline \multirow[b]{2}{*}{ Item } & \multicolumn{5}{|c|}{ Treatments } & \multirow[b]{2}{*}{ SEM* } & \multicolumn{2}{|c|}{$p$-Value } \\
\hline & Basal (B) & $\mathrm{B}+100 \mathrm{ppm}$ & $\mathrm{B}+200 \mathrm{ppm}$ & $\mathrm{B}+400 \mathrm{ppm}$ & $\mathrm{B}+800 \mathrm{ppm}$ & & Linear & Quadratic \\
\hline \multicolumn{9}{|c|}{$1^{\text {st }}$ phase: from 34 to $48 \mathrm{~d}$ of life } \\
\hline Weight at $34 \mathrm{~d}, \mathrm{~g}$ & 823 & 809 & 832 & 798 & 821 & 12.2 & 0.91 & 0.27 \\
\hline Weight at $48 \mathrm{~d}$, g & 1680 & 1657 & 1645 & 1666 & 1679 & 11.5 & 0.30 & 0.10 \\
\hline Daily weight gain, $g$ & 61.6 & 60.0 & 59.1 & 60.6 & 61.5 & 0.82 & 0.30 & 0.10 \\
\hline Daily feed intake, $\mathrm{g}$ & 125 & 120 & 121 & 121 & 122 & 1.36 & 0.84 & 0.06 \\
\hline Feed conversion ratio, g/g & 2.03 & 2.01 & 2.04 & 2.00 & 1.99 & 0.01 & $<0.05$ & 0.83 \\
\hline \multicolumn{9}{|c|}{$2^{\text {nd }}$ phase: from 49 to $60 \mathrm{~d}$ of life } \\
\hline Weight at $60 \mathrm{~d}, \mathrm{~g}$ & 2295 & 2287 & 2264 & 2315 & 2300 & 15.9 & 0.30 & 0.86 \\
\hline Daily weight gain, $g$ & 51.3 & 52.5 & 51.6 & 54.1 & 51.7 & 0.69 & 0.59 & $<0.05$ \\
\hline Daily feed intake, $g$ & 164 & 167 & 166 & 166 & 168 & 1.71 & 0.17 & 0.95 \\
\hline Feed conversion ratio, $\mathrm{g} / \mathrm{g}$ & 3.21 & 3.19 & 3.23 & 3.08 & 3.26 & 0.03 & 0.41 & $<0.05$ \\
\hline \multicolumn{9}{|c|}{ Whole phase: from 34 to $60 \mathrm{~d}$ of life } \\
\hline Daily weight gain, $\mathrm{g}$ & 56.8 & 56.5 & 55.6 & 57.6 & 57.0 & 0.61 & 0.30 & 0.86 \\
\hline Daily feed intake, $\mathrm{g}$ & 143 & 142 & 141 & 142 & 143 & 1.34 & 0.48 & 0.31 \\
\hline Feed conversion ratio, g/g & 2.52 & 2.51 & 2.54 & 2.46 & 2.52 & 0.02 & 0.58 & 0.07 \\
\hline
\end{tabular}

*SEM: Standard Error of Means ( $\mathrm{n}=45$ animals/treatment). 
Table 10. Effect of enzyme dose supplementation (100, 200, 400 and $800 \mathrm{ppm})$ on slaughter traits at 62 d. (Experiment 1)

\begin{tabular}{lcccccccc}
\hline & \multicolumn{3}{c}{ Treatments } & \multicolumn{2}{c}{$p$-Value } \\
\cline { 2 - 6 } Item & Basal (B) & B+ 100ppm & B+ 200ppm & B+ 400ppm & B+ 800ppm & SEM* & Linear & Quadratic \\
\hline Body weight at slaughter, g & 2372 & 2321 & 2347 & 2373 & 2364 & 16.7 & 0.43 & 0.87 \\
Cold carcass weight, g & 1280 & 1235 & 1256 & 1268 & 1265 & 11.3 & 0.70 & 0.45 \\
Carcass yield, \% & 58.2 & 57.4 & 57.9 & 57.6 & 57.8 & 0.29 & 0.69 & 0.35 \\
Digestive tract weight, \% BW & 17.4 & 17.8 & 17.6 & 17.9 & 18.2 & 0.25 & $<0.05$ & 0.64 \\
Liver weight, \% BW & 4.17 & 4.19 & 4.40 & 4.18 & 4.25 & 0.11 & 0.82 & 0.62 \\
Full stomach weight, \% BW & 4.25 & 4.62 & 4.21 & 4.55 & 4.58 & 0.14 & 0.17 & 0.83 \\
Empty stomach weight, \% BW & 0.89 & 0.96 & 0.94 & 0.94 & 0.95 & 0.02 & 0.13 & 0.17 \\
Full caecal weight, \% BW & 6.55 & 6.67 & 6.92 & 6.66 & 6.87 & 0.17 & 0.31 & 0.69 \\
\hline
\end{tabular}

*SEM: Standard Error of Means ( $\mathrm{n}=24$ animals/treatment).

\# Body weight.

Table 11. Effect of enzyme dose supplementation (100, 200, 400 and $800 \mathrm{ppm}$ ) on apparent total-tract digestibility (ATTD) from 53 to $57 \mathrm{~d}$ of age. (Experiment 1)

\begin{tabular}{|c|c|c|c|c|c|c|c|}
\hline \multirow[b]{2}{*}{ Item } & \multicolumn{4}{|c|}{ Treatments } & \multirow[b]{2}{*}{ SEM* $*$} & \multicolumn{2}{|c|}{$p$-Value } \\
\hline & Basal (B) & $\mathrm{B}+200 \mathrm{ppm}$ & $\mathrm{B}+400 \mathrm{ppm}$ & $\mathrm{B}+800 \mathrm{ppm}$ & & Linear & Quadratic \\
\hline $\begin{array}{l}\text { Dry matter intake, } \mathrm{g} / \mathrm{d} \\
\text { Digestibility Coefficients, \% }\end{array}$ & 150 & 154 & 155 & 151 & 5.10 & 0.90 & 0.38 \\
\hline Dry Matter & 58.4 & 57.3 & 56.8 & 56.6 & 0.48 & $<0.05$ & 0.19 \\
\hline Organic Matter & 60.3 & 58.9 & 58.9 & 58.4 & 0.50 & $<0.05$ & 0.26 \\
\hline Crude Protein & 69.3 & 67.1 & 68.0 & 67.5 & 0.80 & 0.22 & 0.35 \\
\hline Gross Energy & 59.9 & 58.5 & 57.1 & 56.8 & 0.47 & $<0.001$ & 0.03 \\
\hline Neutral Detergent Fibre & 19.2 & 20.8 & 20.0 & 19.1 & 1.11 & 0.69 & 0.36 \\
\hline Ether Extract & 86.6 & 86.4 & 85.6 & 84.7 & 0.45 & $<0.05$ & 0.88 \\
\hline
\end{tabular}

* SEM: Standard Error of Means ( $\mathrm{n}=11$ animals/treatment). 
Table 12. Effect of enzyme dose supplementation (100, 200, 400 and 800 ppm) on carcass chemical composition at 34 and $60 \mathrm{~d}$ of age. (Experiment 1)

\begin{tabular}{|c|c|c|c|c|c|c|c|c|}
\hline \multirow[b]{2}{*}{ Item } & \multicolumn{5}{|c|}{ Treatments } & \multirow[b]{2}{*}{ SEM* } & \multicolumn{2}{|c|}{$p$-Value } \\
\hline & Basal (B) & $\mathrm{B}+100 \mathrm{ppm}$ & $\mathrm{B}+200 \mathrm{ppm}$ & $\mathrm{B}+400 \mathrm{ppm}$ & $\mathrm{B}+$ 800ppm & & Linear & Quadratic \\
\hline \multicolumn{9}{|c|}{ Carcass composition at $34 \mathrm{~d}$ of age, \% DM } \\
\hline Body weight, g & 798 & 836 & 808 & 781 & 803 & 32.0 & 0.67 & 0.71 \\
\hline Water, \% & 71.1 & 71.3 & 71.2 & 71.4 & 71.2 & 0.15 & 0.79 & 0.35 \\
\hline Crude Protein & 62.7 & 63.2 & 62.8 & 63.2 & 63.0 & 0.47 & 0.73 & 0.56 \\
\hline Ash & 16.1 & 16.0 & 16.2 & 16.1 & 16.1 & 0.22 & 0.90 & 0.80 \\
\hline Ether extract & 19.5 & 22.0 & 19.6 & 19.1 & 19.4 & 1.26 & 0.42 & 0.76 \\
\hline Gross Energy, kJ/100 g DM & 2114 & 2124 & 2109 & 2109 & 2114 & 13.7 & 0.80 & 0.71 \\
\hline \multicolumn{9}{|c|}{ Carcass composition at $60 \mathrm{~d}$ of life, \% DM } \\
\hline Body weight, g & 2292 & 2294 & 2277 & 2261 & 2286 & 62.7 & 0.90 & 0.71 \\
\hline Water, \% & 66.8 & 66.7 & 67.1 & 66.7 & 66.6 & 0.31 & 0.57 & 0.73 \\
\hline Crude Protein & 55.3 & 54.8 & 55.8 & 54.9 & 55.4 & 0.70 & 0.88 & 0.86 \\
\hline Ash & 12.6 & 12.5 & 12.7 & 12.5 & 12.5 & 0.36 & 0.91 & 0.99 \\
\hline Ether extract & 29.2 & 29.8 & 28.5 & 29.7 & 29.5 & 0.69 & 0.77 & 0.94 \\
\hline Gross Energy, kJ/100 g DM & 2446 & 2451 & 2434 & 2453 & 2445 & 26.4 & 0.97 & 0.97 \\
\hline
\end{tabular}

* SEM: Standard Error of Means $(\mathrm{n}=15$ animals/treatment). 
Table 13. Effect of enzyme dose supplementation (100, 200, 400 and 800 ppm) on nitrogen and energy balance from 34 to 60 d. (Experiment 1 ). Treatments

\begin{tabular}{|c|c|c|c|c|c|c|c|}
\hline Item & Basal (B) & $\mathrm{B}+200 \mathrm{ppm}$ & $\mathrm{B}+400 \mathrm{ppm}$ & $\mathrm{B}+800 \mathrm{ppm}$ & SEM $^{*}$ & Linear & Quadratic \\
\hline \multicolumn{8}{|c|}{ Nitrogen intake $^{\#}\left[\mathrm{~g} / \mathrm{kg} \mathrm{BW}^{0.75} . \mathrm{d}\right]:$} \\
\hline $\mathrm{Ni}$ & 2.590 & 2.619 & 2.634 & 2.617 & 0.042 & 0.699 & 0.519 \\
\hline $\mathrm{DNi}$ & 1.792 & 1.746 & 1.798 & 1.760 & 0.031 & 0.716 & 0.929 \\
\hline \multicolumn{8}{|c|}{ Nitrogen retained ${ }^{\#}\left[\mathrm{~g} / \mathrm{kg} \mathrm{BW}^{0.75} . \mathrm{d}\right]^{1}$ : } \\
\hline NR body & 1.103 & 1.093 & 1.104 & 1.094 & 0.019 & 0.818 & 0.957 \\
\hline NR carcass & 0.535 & 0.541 & 0.537 & 0.529 & 0.010 & 0.571 & 0.591 \\
\hline \multicolumn{8}{|l|}{ Nitrogen efficiency } \\
\hline NR body/DNi & 0.617 & 0.626 & 0.614 & 0.624 & 0.013 & 0.816 & 0.894 \\
\hline \multirow{2}{*}{\multicolumn{8}{|c|}{ Nitrogen losses $\left[\mathrm{g} / \mathrm{kg} \mathrm{BW}^{0.75} . \mathrm{d}\right]$}} \\
\hline & & & & & & & \\
\hline Skin and Viscera & 0.567 & 0.553 & 0.567 & 0.564 & 0.010 & 0.845 & 0.759 \\
\hline Faeces & 0.799 & 0.873 & 0.836 & 0.856 & 0.003 & 0.218 & 0.264 \\
\hline Urine & 0.688 & 0.654 & 0.695 & 0.667 & 0.032 & 0.847 & 0.929 \\
\hline \multicolumn{8}{|c|}{ Energy intake ${ }^{\#}, \mathrm{MJ} / \mathrm{kg} \mathrm{BW}^{0.75} . \mathrm{d}$} \\
\hline GEi & 1.671 & 1.693 & 1.684 & 1.688 & 0.027 & 0.763 & 0.766 \\
\hline DEi & 1.004 & 0.992 & 0.964 & 0.956 & 0.016 & $<0.05$ & 0.506 \\
\hline \multicolumn{8}{|c|}{ Energy retained ${ }^{\#}, \mathrm{~kJ} / \mathrm{kg} \mathrm{BW}^{0.75} \cdot \mathrm{d}^{2}$} \\
\hline ER body & 394 & 385 & 396 & 391 & 11.718 & 0.969 & 0.980 \\
\hline ER carcass & 233 & 229 & 233 & 232 & 7.490 & 0.995 & 0.899 \\
\hline \multicolumn{8}{|l|}{ Energy efficiency } \\
\hline ER body/Dei & 0.394 & 0.385 & 0.396 & 0.391 & 0.012 & 0.961 & 0.989 \\
\hline ER carcass/DEi & 0.233 & 0.229 & 0.233 & 0.232 & 0.007 & 0.990 & 0.907 \\
\hline \multicolumn{8}{|c|}{ Energy losses, $\mathrm{MJ} / \mathrm{kg} \mathrm{BW}^{0.75}$.d } \\
\hline Skin and viscera & 0.159 & 0.155 & 0.163 & 0.160 & 0.005 & 0.695 & 0.774 \\
\hline Faeces & 0.644 & 0.675 & 0.691 & 0.706 & 0.012 & $<0.05$ & 0.197 \\
\hline Urine + heat production & 0.609 & 0.606 & 0.567 & 0.567 & 0.018 & 0.065 & 0.541 \\
\hline
\end{tabular}

** Standard Error of Means ( $\mathrm{n}=11$ animals/treatment). \#Ni: nitrogen intake. DNi: digestible nitrogen intake. NR: nitrogen retained. GEi: gross energy intake. DEi: digestible energy intake. ER: energy retained. Skin and viscera $\left(\mathrm{g} / \mathrm{kg} \mathrm{BW}^{0.75}\right.$ and $\left.\mathrm{d}\right):\left(\mathrm{g} \mathrm{N}\right.$ retained in body $-\mathrm{g}$ retained in carcass) $/ \mathrm{kg} \mathrm{BW}^{0.75}$ and $\mathrm{d}$.

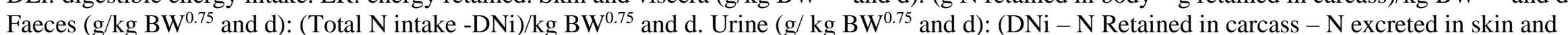
viscera) $/ \mathrm{kg} \mathrm{BW}^{0.75}$ and $\mathrm{d}$.

Skin and viscera $\left(\mathrm{MJ} / \mathrm{kg} \mathrm{BW}^{0.75}\right.$ and d): (MJ gross energy retained in - MJ gross energy retained in carcass) $/ \mathrm{kg} \mathrm{BW}^{0.75}$ and d.

Faeces $\left(\mathrm{MJ} / \mathrm{kg} \mathrm{BW}^{0.75}\right.$ and d): (Gross Energy intake -DEi) $/ \mathrm{kg} \mathrm{BW}^{0.75}$ and d. Urine + heat production $\left(\mathrm{MJ} / \mathrm{kg} \mathrm{BW}^{0.75}\right.$ and d): (DEi - Gross energy retained in carcass - GE excreted in skin and viscera) $/ \mathrm{kg} \mathrm{BW}^{0.75}$ and $\mathrm{d}$. 


\subsection{Experiment 2: Effect of an enzyme complex in a protein and energy reduced diet on productive performance, slaughter traits and nitrogen and energy balance in growing rabbits.}

\subsubsection{Growth performance}

Enzyme dose did not influence on any of the zootechnical parameters studied ( $\mathrm{P}>0.05$; Table 14). Any interaction between diet and dose was observed $(\mathrm{P}>0.05)$. However, diet had a significant effect $(\mathrm{P}<0.05)$ on live weight at $48 \mathrm{~d}(1650$ vs. $1622 \mathrm{~g}$ on average, for diet $\mathrm{A}$ and $\mathrm{B}$, respectively) and tended $(\mathrm{P}=0.095)$ to reduce live weight at $60 \mathrm{~d}$ in the rabbits fed the diet B, with lower DP/DE. There was a significant effect of live weight at weaning (34 d), therefore, initial live weight was used as a covariable for the analyses of productive performance.

In $\mathrm{B}$ diet feed intake tended $(\mathrm{P}=0.057)$ to be higher in the first phase, whereas in the second phase (49 to $60 \mathrm{~d}$ ) and during the whole fattening (34 to $60 \mathrm{~d}$ ) it was $+3.74 \%$ and +2.92 significantly $(\mathrm{P}<0.05)$ higher than in $\operatorname{diet} \mathrm{A}$.

In diet A DWG tended to be higher $(+3.4 \%, \mathrm{P}<0.05)$ in the first phase $(34$ to 48 d). However, during the second phase this effect disappear and there was not observed any significance $(\mathrm{P}>0.05)$ between diets $(52.05 \mathrm{~g} / \mathrm{d}$ on average). In the whole phase (34 to $60 \mathrm{~d}) \mathrm{DWG}$ in $\operatorname{diet} \mathrm{A}$ tended $(\mathrm{P}=0.095)$ to be higher.

Mortality was low (1.85\% on average) and no effect of diet, enzyme dose or interaction was observed. 


\subsubsection{Slaughter traits}

Enzyme supplementation did not show any significant effect on the slaughter traits studied. No interaction between diet and enzyme dose was observed.

Animals fed diet A showed higher body weight at slaughter (2337 vs. $2295 \mathrm{~g}$ and cold carcass weight (1250 vs. $1225 \mathrm{~g})(\mathrm{P}<0.05$; Table 15) than rabbits of the diet $\mathrm{B}$. On the contrary, digestive tract weight, full and empty stomach weights were higher in diet B. Neither carcass yield nor liver nor full caecal weights were affected by any of the treatments.

\subsubsection{Apparent total-tract digestibility (ATTD)}

Enzyme supplementation had no effect $(\mathrm{P}>0.05)$ on the digestibility of any of the nutrients studied (Table 16).

Diet did not show any significant $(\mathrm{P}>0.05)$ effect in $\mathrm{DM}$ and $\mathrm{OM}$ intakes, $\mathrm{CP}$, ash and EE digestibility. However, DM, OM, NDF and GE digestibility was impaired in diet B (-5.98; $-5.53 ;-24.5$ and $-4.90 \%$, respectively, $\mathrm{P}<0.05)$. 
Table 14. Effect of enzyme dose supplementation $(0,100,200 \mathrm{ppm})$ and type of diet on zootechnical parameters in rabbits from 34 to $60 \mathrm{~d}$ of age.

(Experiment 2)

\begin{tabular}{|c|c|c|c|c|c|c|c|c|c|c|c|c|c|c|c|c|c|}
\hline \multirow[b]{2}{*}{ Item } & \multicolumn{2}{|c|}{$\underline{\text { Diet }}$} & \multicolumn{3}{|c|}{ Enzyme dose, ppm } & \multicolumn{3}{|c|}{$\underline{\text { Diet A }}$} & \multicolumn{3}{|c|}{ Diet B } & \multicolumn{3}{|c|}{$\underline{\text { SEM}^{*}}$} & \multicolumn{3}{|c|}{$p$-Value } \\
\hline & A & B & 0 & 100 & 200 & 0 & 100 & 200 & 0 & 100 & 200 & Diet & Enz & $\begin{array}{c}\text { Diet } \\
x \\
\text { Enz }\end{array}$ & Diet & Enz. & $\begin{array}{c}\text { Diet x } \\
\text { Enz }\end{array}$ \\
\hline \multicolumn{18}{|c|}{$1^{\text {st }}$ phase: from 34 to $48 \mathrm{~d}$} \\
\hline Weight at $34 \mathrm{~d}, \mathrm{~g}$ & 821 & 791 & 814 & 797 & 808 & 825 & 810 & 828 & 803 & 784 & 788 & 7.12 & 8.73 & 12.3 & $<0.05$ & 0.37 & 0.74 \\
\hline Weight at $48 \mathrm{~d}$, g & 1650 & 1622 & 1642 & 1644 & 1624 & 1669 & 1643 & 1640 & 1614 & 1645 & 1608 & 6.87 & 8.35 & 11.8 & $<0.05$ & 0.18 & 0.05 \\
\hline Daily weight gain, $g$ & 60.2 & 58.2 & 59.6 & 59.7 & 58.3 & 61.5 & 59.6 & 59.4 & 57.6 & 59.8 & 57.1 & 0.49 & 0.60 & 0.84 & $<0.05$ & 0.18 & 0.05 \\
\hline Daily feed intake, $\mathrm{g}$ & 121 & 124 & 124 & 123 & 121 & 124 & 120 & 120 & 124 & 126 & 122 & 0.88 & 1.07 & 1.51 & 0.057 & 0.11 & 0.08 \\
\hline $\begin{array}{l}\text { Feed conversion } \\
\text { ratio, g/g }\end{array}$ & 2.02 & 2.13 & 2.09 & 2.06 & 2.08 & 2.02 & 2.01 & 2.03 & 2.16 & 2.11 & 2.13 & 0.01 & 0.01 & 0.02 & $<0.001$ & 0.19 & 0.47 \\
\hline \multicolumn{18}{|c|}{$2^{\text {nd }}$ phase: from 49 to $60 \mathrm{~d}$} \\
\hline Weight at $60 \mathrm{~d}$, g & 2272 & 2250 & 2270 & 2268 & 2244 & 2285 & 2270 & 2262 & 2256 & 2267 & 2227 & 9.40 & 11.4 & 16.1 & 0.095 & 0.21 & 0.57 \\
\hline Daily weight gain, $g$ & 51.8 & 52.3 & 52.4 & 52.0 & 51.7 & 51.3 & 52.2 & 51.9 & 53.5 & 51.8 & 51.6 & 0.45 & 0.54 & 0.76 & 0.434 & 0.69 & 0.17 \\
\hline Daily feed intake, $g$ & 165 & 171 & 167 & 170 & 167 & 164 & 166 & 166 & 171 & 174 & 169 & 1.16 & 1.41 & 1.99 & $<0.05$ & 0.34 & 0.38 \\
\hline $\begin{array}{l}\text { Feed conversion } \\
\text { ratio, } \mathrm{g} / \mathrm{g}\end{array}$ & 3.20 & 3.29 & 3.21 & 3.28 & 3.25 & 3.20 & 3.19 & 3.22 & 3.22 & 3.37 & 3.29 & 0.02 & 0.03 & 0.04 & $<0.05$ & 0.21 & 0.10 \\
\hline \multicolumn{18}{|c|}{ Whole phase: from 34 to $60 \mathrm{~d}$} \\
\hline Daily weight gain, $g$ & 56.3 & 55.5 & 56.2 & 56.2 & 55.2 & 56.8 & 56.2 & 55.9 & 55.7 & 56.1 & 54.6 & 0.36 & 0.44 & 0.62 & 0.095 & 0.21 & 0.57 \\
\hline Daily feed intake, $g$ & 142 & 146 & 144 & 144 & 142 & 142 & 141 & 141 & 146 & 148 & 143 & 0.86 & 1.05 & 1.48 & $<0.05$ & 0.32 & 0.23 \\
\hline $\begin{array}{l}\text { Feed conversion } \\
\text { ratio, } \mathrm{g} / \mathrm{g}\end{array}$ & 2.52 & 2.63 & 2.56 & 2.57 & 2.58 & 2.51 & 2.51 & 2.53 & 2.62 & 2.64 & 2.63 & 0.01 & 0.01 & 0.02 & $<0.001$ & 0.70 & 0.60 \\
\hline
\end{tabular}

\footnotetext{
* Standard Error of Means ( $\mathrm{n}=45$ animals/treatment).
} 
Table 15. Effect of enzyme dose supplementation $(0,100,200 \mathrm{ppm})$ and type of diet on slaughter traits at 62 d. (Experiment 2)

\begin{tabular}{|c|c|c|c|c|c|c|c|c|c|c|c|c|c|c|c|c|c|}
\hline \multirow[b]{2}{*}{ Item } & \multicolumn{2}{|c|}{$\underline{\text { Diet }}$} & \multicolumn{3}{|c|}{ Enzyme dose, ppm } & \multicolumn{3}{|c|}{$\underline{\text { Diet A }}$} & \multicolumn{3}{|c|}{$\underline{\text { Diet B }}$} & \multicolumn{3}{|c|}{$\underline{\text { SEM }^{*}}$} & \multicolumn{3}{|c|}{$p$-Value } \\
\hline & A & B & 0 & 100 & 200 & 0 & 100 & 200 & 0 & 100 & 200 & Diet & Enz. & $\begin{array}{l}\text { Diet x } \\
\text { Enz. }\end{array}$ & Diet & Enz. & $\begin{array}{c}\text { Diet x } \\
\text { Enz. }\end{array}$ \\
\hline $\begin{array}{l}\text { Body weight at } \\
\text { slaughter, g }\end{array}$ & 2337 & 2295 & 2336 & 2311 & 2301 & 2362 & 2313 & 2337 & 2310 & 2310 & 2266 & 10.9 & 13.3 & 18.8 & $<0.05$ & 0.17 & 0.18 \\
\hline $\begin{array}{l}\text { Cold Carcass } \\
\text { weight, g }\end{array}$ & 1250 & 1225 & 1250 & 1231 & 1232 & 1273 & 1229 & 1249 & 1227 & 1232 & 1215 & 6.99 & 8.5 & 12.0 & $<0.05$ & 0.19 & 0.11 \\
\hline Carcass yield, $\%$ & 57.8 & 57.7 & 57.8 & 57.5 & 57.8 & 58.1 & 57.3 & 57.8 & 57.5 & 57.6 & 57.9 & 0.16 & 0.20 & 0.28 & 0.66 & 0.32 & 0.31 \\
\hline $\begin{array}{l}\text { Digestive tract } \\
\text { weight, } \% \mathrm{BW}^{\#}\end{array}$ & 17.7 & 18.6 & 18.1 & 18.1 & 18.2 & 17.4 & 17.9 & 17.7 & 18.7 & 18.4 & 18.7 & 0.14 & 0.18 & 0.25 & $<0.001$ & 0.89 & 0.22 \\
\hline $\begin{array}{l}\text { Liver weight, \% } \\
\text { BW }\end{array}$ & 4.26 & 4.29 & 4.29 & 4.23 & 4.31 & 4.18 & 4.21 & 4.40 & 4.41 & 4.25 & 4.21 & 0.07 & 0.08 & 0.12 & 0.77 & 0.78 & 0.21 \\
\hline $\begin{array}{l}\text { Full stomach } \\
\text { weight, \%BW }\end{array}$ & 4.37 & 4.95 & 4.65 & 4.74 & 4.59 & 4.26 & 4.64 & 4.21 & 5.04 & 4.84 & 4.96 & 0.08 & 0.10 & 0.13 & $<0.001$ & 0.52 & 0.06 \\
\hline $\begin{array}{l}\text { Empty stomach } \\
\text { weight, \%BW }\end{array}$ & 0.93 & 0.97 & 0.93 & 0.96 & 0.96 & 0.89 & 0.96 & 0.95 & 0.97 & 0.96 & 0.97 & 0.01 & 0.01 & 0.02 & $<0.05$ & 0.10 & 0.06 \\
\hline $\begin{array}{l}\text { Full caecal } \\
\text { weight, \%BW }\end{array}$ & 6.77 & 6.91 & 6.74 & 6.74 & 7.04 & 6.61 & 6.71 & 6.98 & 6.87 & 6.76 & 7.10 & 0.10 & 0.12 & 0.17 & 0.30 & 0.11 & 0.81 \\
\hline
\end{tabular}

*Standard Error of Means ( $\mathrm{n}=24$ animals/treatment).

\# BW: Body Weight. 
Table 16. Effect of enzyme dose supplementation (0,200 ppm) and type of diet on apparent total-tract digestibility (ATTD) from 53 to $57 \mathrm{~d}$. (Experiment 2)

\begin{tabular}{|c|c|c|c|c|c|c|c|c|c|c|c|c|c|c|}
\hline \multirow[b]{2}{*}{ Item } & \multicolumn{2}{|c|}{$\underline{\text { Diet }}$} & \multicolumn{2}{|c|}{$\frac{\text { Enzyme }}{\text { dose, } p p m}$} & \multicolumn{2}{|c|}{$\underline{\text { Diet A }}$} & \multicolumn{2}{|c|}{$\underline{\text { Diet B }}$} & \multicolumn{3}{|c|}{$\underline{\text { SEM}^{*}}$} & \multicolumn{3}{|c|}{$p$-Value } \\
\hline & A & B & 0 & 200 & 0 & 200 & 0 & 200 & Diet & Enz. & Diet x Enz & Diet & Enz. & Diet x Enz \\
\hline Dry matter intake, $\mathrm{g} / \mathrm{d}$ & 152 & 155 & 153 & 154 & 150 & 154 & 156 & 153 & 2.98 & 2.98 & 4.21 & 0.49 & 0.89 & 0.38 \\
\hline \multicolumn{15}{|c|}{ Digestibility coefficients, \% } \\
\hline Dry matter & 57.8 & 54.4 & 56.1 & 58.4 & 58.4 & 57.3 & 53.9 & 54.9 & 0.35 & 0.35 & 0.50 & $<0.001$ & 0.96 & 0.06 \\
\hline Organic matter & 59.6 & 56.3 & 58.2 & 57.7 & 60.3 & 58.9 & 56.0 & 56.5 & 0.36 & 0.36 & 0.50 & $<0.001$ & 0.38 & 0.07 \\
\hline Crude protein & 68.2 & 67.7 & 68.1 & 67.8 & 69.3 & 67.1 & 67.0 & 68.5 & 0.67 & 0.68 & 0.95 & 0.61 & 0.75 & 0.06 \\
\hline Gross energy & 59.2 & 56.3 & 57.9 & 57.6 & 59.9 & 58.5 & 55.9 & 56.7 & 0.51 & 0.51 & 0.72 & $<0.05$ & 0.71 & 0.14 \\
\hline $\begin{array}{l}\text { Neutral detergent } \\
\text { fibre }\end{array}$ & 20.0 & 15.1 & 17.0 & 18.1 & 19.2 & 20.8 & 14.8 & 15.4 & 0.83 & 0.83 & 1.18 & $<0.05$ & 0.36 & 0.64 \\
\hline Ether extract & 86.5 & 85.6 & 85.9 & 86.2 & 86.6 & 86.4 & 85.1 & 86.0 & 0.43 & 0.43 & 0.60 & 0.13 & 0.58 & 0.42 \\
\hline
\end{tabular}

$*$ Standard Error of Means $(\mathrm{n}=11$ animals/treatment).

\# BW: Body Weight. 


\subsubsection{Carcass chemical composition and nitrogen and energy balances}

Carcass chemical composition were not affected $(\mathrm{P}>0.05)$ by enzyme complex supplementation. No interaction was neither observed between diet and enzyme supplementation (Table 17).

However, chemical composition was affected by the diet. There were initial significant $(\mathrm{P}<0.05)$ differences of diet on weaning weight $(34 \mathrm{~d})$, crude protein and ether extract and a tendency $(\mathrm{P}=0.06)$ on ash content. Crude protein $(62.3$ vs. $63.8 \% \mathrm{DM})$ was higher in $\mathrm{B}$ than in A diet, while weaning weight (814 vs. $752 \mathrm{~g})$, ash (16.3 vs. 16.1\%DM; $\mathrm{P}=0.06)$ and ether extract (19.5 vs. $19.0 \% \mathrm{DM})$ were lower in B with respect to A.

Each initial parameter was used as a covariable for the statistically analysis of that value at $60 \mathrm{~d}$ of age. Al the end of the trial all parameters were significantly $(\mathrm{P}<0.05)$ affected by the diet. Diet A showed higher body weight (2246 vs. $2181 \mathrm{~g})$, ether extract (29.1 vs. 27.8 $\% \mathrm{DM})$ and gross energy (2440 vs. $2386 \mathrm{~kJ} / 100 \mathrm{~g} \mathrm{DM})$ and a decreased in water (66.9 vs. 67.6 $\%)$, crude protein $(55.5$ vs. $56.6 \% \mathrm{DM})$ and ash $(12.6$ vs. $13.4 \% \mathrm{DM})$ than diet $\mathrm{B}$.

Regarding nitrogen balance there was significant effects on nitrogen intake (Table 18), lower consumption was observed in diet $\mathrm{B}\left(\mathrm{Ni}: 2.604\right.$ vs. $2.388 \mathrm{~g} / \mathrm{kg} \mathrm{BW} \mathrm{BW}^{0.75} \mathrm{~d}$; $\mathrm{P}<0.001$; DNi: 1.769 vs. $1.605 \mathrm{~g} / \mathrm{kg} \mathrm{BW}^{0.75} \mathrm{~d}$; $\left.\mathrm{P}<0.001\right)$ than in diet $\mathrm{A}$. Same effect was observed in the nitrogen retained, both in live body (1.098 vs $\left.1.065 \mathrm{~g} / \mathrm{kg} \mathrm{BW}^{0.75} \mathrm{~d} ; \mathrm{P}=0.07\right)$ and carcass $(0.538$ vs $\left.0.514 \mathrm{~g} / \mathrm{kg} \mathrm{BW}{ }^{0.75} \mathrm{~d} ; \mathrm{P}<0.05\right)$. However, the opposite effect was observed in nitrogen efficiency being higher in diet $\mathrm{B}$ (efficiency in carcass: 0.305 vs. 0.323 ; $\mathrm{P}<0.05$ ). Due to the differences in the nitrogen intake and the efficiency, nitrogen excretion in faeces $(0.836 v s$. 
$\left.0.783 \mathrm{~g} / \mathrm{kg} \mathrm{BW}^{0.75} . \mathrm{d} ; \mathrm{P}<0.05\right)$ and urine $\left(0.671\right.$ vs. $\left.0.51 \mathrm{~g} / \mathrm{kg} \mathrm{BW}^{0.75} . \mathrm{d} ; \mathrm{P}<0.05\right)$ were lower in diet B.

Enzyme supplementation decreased the nitrogen content in skin and viscera (0.565 vs. $\left.0.544 \mathrm{~g} / \mathrm{kg} \mathrm{BW}^{0.75} . \mathrm{d} ; \mathrm{P}<0.05\right)$.

There was an interaction between diet and enzyme dose for nitrogen excreted in faeces. Enzyme supplementation in diet A increases the nitrogen excretion $(0.799$ vs. $0.873 \mathrm{~g} / \mathrm{kg}$ $\mathrm{BW}^{0.75}$.d) whereas in diet $\mathrm{B}$ the enzyme supplementation decreased its excretion via faeces (0.827 vs. $\left.0.738 \mathrm{~g} / \mathrm{kg} \mathrm{BW}^{0.75} . \mathrm{d}\right)$.

Regarding the energy balance (Table 19), enzyme supplementation did not have any significant effect on energy balance.

Digestible energy intake of diet B was lower $(\mathrm{P}<0.05)$ compared with diet A $(0.998$ vs $0.947 \mathrm{MJ} / \mathrm{kg} \mathrm{BW}^{0.75} . \mathrm{d}$. Accordingly, animals of diet B had lower energy retention efficacy, both in whole body $\left(0.389\right.$ vs. $\left.0.360 \mathrm{~kJ} / \mathrm{kg} \mathrm{BW}{ }^{0.75} . \mathrm{d}\right)$ and in carcass $(0.231$ vs. $0.211 \mathrm{~kJ} / \mathrm{kg}$ $\left.\mathrm{BW}^{0.75} . \mathrm{d}\right)$. Due to the lower energy ingestion and efficacy, energy excreted in faeces was higher $\left(0.660\right.$ vs. $\left.0.705 \mathrm{MJ} / \mathrm{kg} \mathrm{BW}^{0.75} . \mathrm{d} ; \mathrm{P}<0.05\right)$ in animals of diet $\mathrm{B}$, whereas energy excreted in skin and viscera was higher in diet $\mathrm{A}\left(0.157\right.$ vs. $\left.0.148 \mathrm{MJ} / \mathrm{kg} \mathrm{BW}^{0.75} . \mathrm{d}\right)$. 
Table 17. Effect of enzyme dose supplementation (0,100, $200 \mathrm{ppm})$ and type of diet on carcass chemical composition at 34 and $60 \mathrm{~d}$. (Experiment 2)

\begin{tabular}{|c|c|c|c|c|c|c|c|c|c|c|c|c|c|c|c|c|c|}
\hline \multirow[b]{2}{*}{ Item } & \multicolumn{2}{|c|}{$\underline{\text { Diet }}$} & \multicolumn{3}{|c|}{ Enzyme dose, ppm } & \multicolumn{3}{|c|}{$\underline{\text { Diet } A}$} & \multicolumn{3}{|c|}{ Diet B } & \multicolumn{3}{|c|}{$\underline{\mathrm{SEM}^{* *}}$} & \multicolumn{3}{|c|}{$p$-Value } \\
\hline & A & $\mathrm{B}$ & 0 & 100 & 200 & 0 & 100 & 200 & 0 & 100 & 200 & Diet & Enz. & $\begin{array}{c}\text { Diet x } \\
\text { Enz. }\end{array}$ & Diet & Enz. & $\begin{array}{c}\text { Diet x } \\
\text { Enz. }\end{array}$ \\
\hline \multicolumn{18}{|c|}{ Carcass composition at $34 \mathrm{~d}$ of age, \% DM } \\
\hline $\begin{array}{l}\text { Body weight, } \\
\text { g }\end{array}$ & 814 & 752 & 779 & 792 & 778 & 798 & 836 & 808 & 759 & 748 & 748 & 17.8 & 21.8 & 30.9 & $<0.05$ & 0.87 & 0.73 \\
\hline Water, \% & 71.3 & 71.3 & 71.3 & 71.3 & 71.3 & 71.2 & 71.4 & 71.3 & 71.3 & 71.3 & 71.3 & 0.06 & 0.08 & 0.11 & 0.95 & 0.77 & 0.83 \\
\hline Crude protein & 62.9 & 63.8 & 63.3 & 63.3 & 63.4 & 62.8 & 63.0 & 62.8 & 63.8 & 63.5 & 64.0 & 0.20 & 0.24 & 0.35 & $<0.05$ & 0.89 & 0.65 \\
\hline Ash & 16.3 & 16.1 & 16.2 & 16.1 & 16.3 & 16.2 & 16.2 & 16.4 & 16.2 & 16.0 & 16.2 & 0.06 & 0.07 & 0.11 & 0.06 & 0.49 & 0.78 \\
\hline Ether extract & 19.5 & 19.0 & 19.3 & 19.2 & 19.2 & 19.5 & 19.4 & 19.5 & 19.0 & 19.0 & 18.9 & 0.08 & 0.10 & 0.14 & $<0.05$ & 0.87 & 0.89 \\
\hline $\begin{array}{l}\text { Gross Energy, } \\
\text { kJ/100 g DM }\end{array}$ & 2101 & 2107 & 2104 & 2108 & 2100 & 2103 & 2103 & 2097 & 2104 & 2112 & 2104 & 3.04 & 3.71 & 5.26 & 0.19 & 0.38 & 0.74 \\
\hline \multicolumn{18}{|c|}{ Carcass composition at $60 \mathrm{~d}$ of age, $\% \mathrm{DM}$} \\
\hline $\begin{array}{l}\text { Body weight, } \\
\text { g }\end{array}$ & 2246 & 2181 & 2245 & 2212 & 2183 & 2284 & 2223 & 2230 & 2206 & 2201 & 2136 & 18.8 & 22.3 & 31.9 & $<0.05$ & 0.17 & 0.48 \\
\hline Water, \% & 66.9 & 67.6 & 67.2 & 67.1 & 67.5 & 66.8 & 66.7 & 67.1 & 67.6 & 67.4 & 67.9 & 0.14 & 0.18 & 0.25 & $<0.05$ & 0.23 & 0.95 \\
\hline Crude protein & 55.5 & 56.6 & 55.9 & 55.7 & 56.5 & 55.5 & 54.8 & 56.0 & 56.3 & 56.5 & 57.1 & 0.33 & 0.39 & 0.56 & $<0.05$ & 0.29 & 0.72 \\
\hline Ash & 12.6 & 13.4 & 12.9 & 13.0 & 13.1 & 12.5 & 12.5 & 12.7 & 13.3 & 13.4 & 13.6 & 0.16 & 0.19 & 0.27 & $<0.05$ & 0.70 & 0.97 \\
\hline Ether extract & 29.1 & 27.8 & 28.7 & 28.8 & 27.8 & 29.2 & 29.5 & 28.5 & 28.1 & 28.1 & 27.2 & 0.26 & 0.32 & 0.46 & $<0.05$ & 0.16 & 0.94 \\
\hline $\begin{array}{l}\text { Gross Energy, } \\
\text { kJ/100 g DM }\end{array}$ & 2440 & 2386 & 2422 & 2412 & 2404 & 2447 & 2440 & 2432 & 2397 & 2383 & 2376 & 8.75 & 1.7 & 15.16 & $<0.05$ & 0.64 & 0.98 \\
\hline
\end{tabular}


Table 18. Effect of enzyme dose supplementation (0,200 ppm) and type of diet on nitrogen balance from 34 to $60 \mathrm{~d}$. (Experiment 2)

\begin{tabular}{|c|c|c|c|c|c|c|c|c|c|c|c|c|c|c|}
\hline \multirow[b]{2}{*}{ Item } & \multicolumn{2}{|c|}{$\underline{\text { Diet }}$} & \multicolumn{2}{|c|}{$\frac{\text { Enzyme dose, }}{\mathrm{ppm}}$} & \multicolumn{2}{|c|}{$\underline{\operatorname{Diet} A}$} & \multicolumn{2}{|c|}{$\underline{\text { Diet B }}$} & \multicolumn{3}{|c|}{$\underline{\text { SEM }^{*}}$} & \multicolumn{3}{|c|}{$\underline{p \text {-Value }}$} \\
\hline & A & B & 0 & 200 & 0 & 200 & 0 & 200 & Diet & Enz. & $\begin{array}{l}\text { Diet x } \\
\text { Enz }\end{array}$ & Diet & Enz. & $\begin{array}{c}\text { Diet } x \\
\text { Enz }\end{array}$ \\
\hline \multicolumn{15}{|c|}{ Nitrogen intake\#, g/kg BW $\mathbf{B W}^{0.75} . \mathrm{d}$} \\
\hline $\mathrm{Ni}$ & 2.604 & 2.388 & 2.519 & 2.474 & 2.590 & 2.619 & 2.448 & 2.329 & 0.031 & 0.031 & 0.044 & $<0.001$ & 0.31 & 0.10 \\
\hline $\mathrm{DNi}$ & 1.769 & 1.605 & 1.706 & 1.668 & 1.792 & 1.746 & 1.620 & 1.590 & 0.031 & 0.023 & 0.032 & $<0.001$ & 0.24 & 0.81 \\
\hline \multicolumn{15}{|c|}{ Nitrogen retained ${ }^{\#}, \mathrm{~g} / \mathrm{kg} \mathrm{BW}^{0.75} . \mathrm{d}^{1}$} \\
\hline NR body & 1.098 & 1.065 & 1.093 & 1.069 & 1.103 & 1.093 & 1.083 & 1.046 & 0.013 & 0.013 & 0.018 & 0.07 & 0.20 & 0.46 \\
\hline NR carcass & 0.538 & 0.514 & 0.528 & 0.524 & 0.535 & 0.541 & 0.521 & 0.507 & 0.008 & 0.008 & 0.011 & $<0.05$ & 0.71 & 0.36 \\
\hline \multicolumn{15}{|c|}{ Nitrogen efficiency } \\
\hline NR body/DNi & 0.622 & 0.664 & 0.643 & 0.643 & 0.617 & 0.626 & 0.668 & 0.660 & 0.010 & 0.010 & 0.014 & $<0.05$ & 0.96 & 0.52 \\
\hline NR carcass/DNi & 0.305 & 0.323 & 0.312 & 0.316 & 0.300 & 0.310 & 0.323 & 0.322 & 0.005 & 0.005 & 0.008 & $<0.05$ & 0.55 & 0.47 \\
\hline \multicolumn{15}{|c|}{ Nitrogen losses, g/kg BW ${ }^{0.75} . \mathrm{d}$} \\
\hline Skin and viscera & 0.560 & 0.549 & 0.565 & 0.544 & 0.567 & 0.553 & 0.562 & 0.535 & 0.007 & 0.007 & 0.009 & 0.23 & $<0.05$ & 0.50 \\
\hline Faeces & 0.836 & 0.783 & 0.813 & 0.805 & $0.799^{\mathrm{ab}}$ & $0.873^{\mathrm{a}}$ & $0.827^{\mathrm{a}}$ & $0.738^{\mathrm{b}}$ & 0.016 & 0.016 & 0.023 & $<0.05$ & 0.74 & $<0.05$ \\
\hline Urine & 0.671 & 0.541 & 0.613 & 0.599 & 0.688 & 0.654 & 0.538 & 0.544 & 0.022 & 0.022 & 0.031 & $<0.05$ & 0.66 & 0.53 \\
\hline
\end{tabular}

** Standard Error of Means ( $\mathrm{n}=11$ animals/treatment).

a,b Values within a row with different superscripts differ significantly at $\mathrm{P}<0.05$.

\# Ni: nitrogen intake. DNi: digestible nitrogen intake. NR: nitrogen retained. Skin and viscera $\left(\mathrm{g} / \mathrm{kg} \mathrm{BW} \mathrm{BW}^{0.75}\right.$ and $\left.\mathrm{d}\right)$ : $(\mathrm{g} \mathrm{N}$ retained in body $-\mathrm{g}$ retained in carcass) $/ \mathrm{kg} \mathrm{BW}^{0.75}$ and d. Faeces (g/kg BW ${ }^{0.75}$ and d): (Total N intake - DNi)/kg BW ${ }^{0.75}$ and d. Urine (g/ $\mathrm{kg} \mathrm{BW}{ }^{0.75}$ and d): (DNi - N Retained in carcass $-\mathrm{N}$ excreted in skin and viscera) $/ \mathrm{kg} \mathrm{BW}^{0.75}$ and $\mathrm{d}$. 
Table 19. Effect of enzyme dose supplementation (0,200 ppm) and type of diet on energy balance from 34 to $60 \mathrm{~d}$. (Experiment 2)

\begin{tabular}{|c|c|c|c|c|c|c|c|c|c|c|c|c|c|c|}
\hline \multirow[b]{2}{*}{ Item } & \multicolumn{2}{|c|}{ Diet } & \multicolumn{2}{|c|}{$\frac{\text { Enzyme dose, }}{\mathrm{ppm}}$} & \multicolumn{2}{|c|}{$\underline{\text { Diet A }}$} & \multicolumn{2}{|c|}{ Diet B } & \multicolumn{3}{|c|}{$\underline{\text { SEM}^{*}}$} & \multicolumn{3}{|c|}{$p$-Value } \\
\hline & A & B & 0 & 200 & 0 & 200 & 0 & 200 & Diet & Enz. & $\begin{array}{l}\text { Diet x } \\
\text { Enz }\end{array}$ & Diet & Enz. & $\begin{array}{c}\text { Diet } x \\
\text { Enz }\end{array}$ \\
\hline \multicolumn{15}{|c|}{ Energy intake\#, MJ/kg BW ${ }^{0.75} . \mathrm{d}$} \\
\hline$\overline{\mathrm{GEi}}$ & 1.682 & 1.678 & 1.686 & 1.674 & 1.671 & 1.693 & 1.700 & 1.656 & 0.021 & 0.021 & 0.030 & 0.90 & 0.71 & 0.28 \\
\hline $\mathrm{DEi}$ & 0.998 & 0.947 & 0.978 & 0.967 & 1.004 & 0.992 & 0.951 & 0.942 & 0.012 & 0.012 & 0.017 & $<0.05$ & 0.54 & 0.92 \\
\hline \multicolumn{15}{|c|}{ Energy retained $^{\#}, \mathrm{~kJ} / \mathrm{kg} \mathrm{BW}^{0.75} \cdot \mathrm{d}^{1}$} \\
\hline ER body & 389 & 360 & 383 & 365 & 394 & 385 & 372 & 347 & 6.948 & 6.948 & 9.824 & $<0.05$ & 0.09 & 0.40 \\
\hline ER carcass & 231 & 211 & 226 & 217 & 233 & 229 & 218 & 204 & 4.621 & 4.621 & 6.534 & $<0.05$ & 0.18 & 0.47 \\
\hline \multicolumn{15}{|l|}{ Energy efficiency } \\
\hline ER body/DEi & 0.389 & 0.360 & 0.383 & 0.366 & 0.394 & 0.385 & 0.372 & 0.347 & 0.007 & 0.007 & 0.010 & $<0.05$ & 0.09 & 0.40 \\
\hline ER carcass/DEi & 0.231 & 0.211 & 0.226 & 0.217 & 0.233 & 0.229 & 0.218 & 0.204 & 0.005 & 0.005 & 0.007 & $<0.05$ & 0.18 & 0.47 \\
\hline \multicolumn{15}{|c|}{ Energy excreted, $\mathrm{MJ} / \mathrm{kg} \mathrm{BW}^{0.75} . \mathrm{d}$} \\
\hline Skin and viscera & 0.157 & 0.148 & 0.157 & 0.149 & 0.159 & 0.155 & 0.154 & 0.142 & 0.003 & 0.003 & 0.005 & $<0.05$ & 0.09 & 0.36 \\
\hline Faeces & 0.660 & 0.705 & 0.683 & 0.681 & $0.644^{\mathrm{b}}$ & $0.675^{\mathrm{ab}}$ & $0.722^{\mathrm{a}}$ & $0.687^{\mathrm{ab}}$ & 0.011 & 0.011 & 0.016 & $<0.05$ & 0.91 & $<0.05$ \\
\hline $\begin{array}{l}\text { Urine + heat } \\
\text { production }\end{array}$ & 0.608 & 0.588 & 0.594 & 0.601 & 0.609 & 0.606 & 0.579 & 0.596 & 0.012 & 0.012 & 0.018 & 0.26 & 0.69 & 0.58 \\
\hline
\end{tabular}

** Standard Error of Means $(\mathrm{n}=11)$. ${ }^{\mathrm{a}, \mathrm{b}}$ Values within a row with different superscripts differ significantly at $\mathrm{P}<0.05$.

GEi: gross energy intake. DEi: digestible energy intake. ER: energy retained. Skin and viscera (MJ/kg BW0.75 and d): (MJ gross energy retained in - MJ gross energy retained in carcass)/kg BW0.75 and d. Faeces (MJ/kg BW0.75 and d): (Gross Energy intake - DEi)/kg BW0.75 and d. Urine + heat production $\left(\mathrm{MJ} / \mathrm{kg} \mathrm{BW}{ }^{0.75}\right.$ and d): (DEi - Gross energy retained in carcass - GE excreted in skin and viscera)/kg BW0.75 and d. 


\subsection{Experiment 3: Effect of different lignin levels and sources on productive performance, slaughter traits, and nitrogen and energy balance in growing rabbits.}

\subsubsection{Growth performance}

In the individual housed rabbits, lignin level did not affect $(\mathrm{P}>0.1)$ on any of the studied parameters, there was neither an interaction $(\mathrm{P}>0.05)$ between the source and level of lignin (Table 20). However, in treatment HA was observed a tendency to impair FCR during the first period and the whole fattening phase $(\mathrm{P}=0.06$ and $\mathrm{P}=0.08$; respectively). This interaction could indicate an effect of the source that is supported by the impairment of FCR with Arbocel ${ }^{\circledR}$ during the second fattening phases $(3.33 v$ s. $3.23 \mathrm{~g} / \mathrm{g} ; \mathrm{P}<0.05)$ and in the global period $(2.56$ vs. $2.52 ; \mathrm{P}<0.05)$, and by the tendency to increase the feed intake during the first phase (129 vs. $127 \mathrm{~g} ; \mathrm{P}=0.07)$ without effect neither on the next period nor on the global one. The growth was similar independently of the source for all the phases.

In the collective housed animals (Table 21), there were a significant effect $(\mathrm{P}<0.05)$ of the source, the level, and an interaction between them on FCR. Like observed in the individual fattening, the rabbits fed with the highest level of Arbocel@ worsen their FCR $(+1,42 \%$, $\mathrm{P}<0.05$ ) however, no effect was observed in the defatted grape seed meal. The highest level of lignin impaired the FCR compared with the other two levels (2.70 vs. $2.66 \mathrm{~g} / \mathrm{g}, \mathrm{P}<0.05)$. Defatted grape seed meal improved FCR compared with Arbocel® $(2.65$ vs. 2.69; $\mathrm{P}<0.05)$. Despite the effect on FCR, no differences were observed $(\mathrm{P}>0.05)$ neither on the feed intake $(139 \mathrm{~g} / \mathrm{d})$ nor on growth $(52.3 \mathrm{~g} / \mathrm{d})$, consequently final weight was similar.

The mortality was extremely low, $0.56 \%$ in the individual cages and $2 \%$ in the group ones, and there were no differences $(\mathrm{P}>0.05)$ among treatments. 


\subsubsection{Slaughter traits}

Body weight at slaughter and carcass weight were significantly influenced by the level of ADL ( $\mathrm{P}<0.05$; Table 22). Rabbits feed the M level of ADL showed the lowest weight for both variables with respect to the other two levels.

Higher lignin levels tended to decrease total digestive tract weight (L: $17.9 \%$ vs. average $\mathrm{M} \& \mathrm{H}: 17.45 \% ; \mathrm{P}=0.052)$. This tendency could be related with the significancy decrease $(\mathrm{P}<0.05)$ observed in full caecal weigh with the increase of lignin level.

Despite the impact on digestive tract weigh, carcass yield was not influenced neither by the level nor by the source of lignin.

\subsubsection{Apparent total-tract digestibility (ATTD)}

Arbocel® presented a lower digestibility for OM (58.9 vs. $59.7 \% ; \mathrm{P}<0.05)$ than defatted grape seed meal (Table 23). Digestibility of DM, OM and GE were higher in the low ADL level treatments than the other two: DM (58.3 vs. 56.75\%), MO (60.2 vs. $58.8 \%)$, GE (60.2 vs. $58.9 \%$ ). CP digestibility was lower in medium lignin level than L level (70.1 vs. 72.6\%; $\mathrm{P}<0.05)$, while $\mathrm{H}$ level had an intermediate value (71.0\%). EE digestibility increased with inclusion of ADL level (85.0, 86.1 and 88.2\%, respectively).

There was an interaction between source and level for EE digestibility because the digestibility in L and M levels with Arbocel® were similar $(85.3 \%$, on average) but $\mathrm{H}$ level was significantly higher (89.4\%), however, when defatted grape seed meal source is used, M and $\mathrm{H}$ lignin level were similar (86.7 \%, on average) but L level had low digestibility (84.6 $\%)$. 
Table 20. Effect of lignin source and level on zootechnical parameters in rabbits from 34 to $60 \mathrm{~d}$ of age, breed in individual cages. (Experiment 3)

\begin{tabular}{|c|c|c|c|c|c|c|c|c|c|c|c|c|c|c|c|c|c|}
\hline & \multicolumn{2}{|c|}{$\underline{\text { Source }(\mathrm{S})}$} & \multicolumn{2}{|r|}{$\underline{\text { Level }(\mathrm{L}) * *}$} & \multicolumn{4}{|c|}{$\operatorname{Arbocel}^{\circledR}(\mathrm{A})$} & \multicolumn{3}{|c|}{$\begin{array}{c}\text { Defatted Grape Seed } \\
\text { Meal }(\mathrm{G})\end{array}$} & \multicolumn{3}{|c|}{$\underline{\text { SEM}^{*}}$} & \multicolumn{3}{|c|}{$\underline{P \text {-value }}$} \\
\hline & $\mathrm{A}$ & G & $\begin{array}{c}\text { Low } \\
(\mathrm{L})\end{array}$ & $\begin{array}{l}\text { Medium } \\
(\mathrm{M})\end{array}$ & $\begin{array}{l}\text { High } \\
(\mathrm{H})\end{array}$ & $\mathrm{L}$ & M & $\mathrm{H}$ & $\mathrm{L}$ & M & $\mathrm{H}$ & $\mathrm{S}$ & $\mathrm{L}$ & SxL & $\mathrm{S}$ & $\mathrm{L}$ & SxL \\
\hline \multicolumn{18}{|c|}{$1^{\text {st }}$ phase: from 34 to $48 \mathrm{~d}$} \\
\hline Weight at $34 \mathrm{~d}, \mathrm{~g}$ & 922 & 909 & 922 & 907 & 918 & 925 & 909 & 931 & 919 & 905 & 904 & 7.25 & 8.81 & 12.3 & 0.21 & 0.46 & 0.56 \\
\hline Weight at $48 \mathrm{~d}, \mathrm{~g}$ & 1807 & 1796 & 1803 & 1795 & 1806 & 1804 & 1809 & 1807 & 1803 & 1781 & 1804 & 6.25 & 7.59 & 10.6 & 0.20 & 0.53 & 0.35 \\
\hline Daily weight gain, $\mathrm{g}$ & 63.4 & 62.6 & 63.1 & 62.5 & 63.3 & 63.2 & 63.5 & 63.4 & 63.1 & 61.5 & 63.2 & 0.45 & 0.54 & 0.76 & 0.21 & 0.53 & 0.35 \\
\hline Daily feed intake, $g$ & 129 & 127 & 128 & 128 & 130 & 128 & 129 & 132 & 127 & 126 & 128 & 0.84 & 1.02 & 1.43 & 0.07 & 0.13 & 0.46 \\
\hline $\begin{array}{l}\text { Feed conversion } \\
\text { ratio, } \mathrm{g} / \mathrm{g}\end{array}$ & 2.05 & 2.04 & 2.02 & 2.05 & 2.06 & 2.02 & 2.03 & 2.08 & 2.02 & 2.06 & 2.03 & 0.01 & 0.01 & 0.02 & 0.64 & 0.12 & 0.06 \\
\hline \multicolumn{18}{|c|}{$2^{\text {nd }}$ phase: from 49 to $60 \mathrm{~d}$} \\
\hline Weight at $60 \mathrm{~d}, \mathrm{~g}$ & 2405 & 2406 & 2407 & 2396 & 2414 & 2407 & 2406 & 2402 & 2407 & 2386 & 2426 & 9.79 & 11.9 & 16.6 & 0.90 & 0.53 & 0.38 \\
\hline Daily weight gain, $\mathrm{g}$ & 49.8 & 50.9 & 50.3 & 50.1 & 50.7 & 50.3 & 49.7 & 49.5 & 50.4 & 50.5 & 51.8 & 0.50 & 0.62 & 0.86 & 0.13 & 0.78 & 0.41 \\
\hline Daily feed intake, $g$ & 165 & 163 & 164 & 163 & 166 & 164 & 165 & 166 & 164 & 160 & 166 & 1.18 & 1.44 & 2.01 & 0.28 & 0.22 & 0.37 \\
\hline $\begin{array}{l}\text { Feed conversion } \\
\text { ratio, } \mathrm{g} / \mathrm{g}\end{array}$ & 3.33 & 3.23 & 3.28 & 3.27 & 3.29 & 3.28 & 3.34 & 3.37 & 3.28 & 3.19 & 3.21 & 0.02 & 0.03 & 0.04 & $<0.05$ & 0.87 & 0.11 \\
\hline \multicolumn{18}{|c|}{ Whole phase: from 34 to $60 \mathrm{~d}$} \\
\hline Daily weight gain, $\mathrm{g}$ & 57.1 & 57.2 & 57.2 & 56.8 & 57.5 & 57.2 & 57.2 & 57.0 & 57.2 & 56.4 & 57.9 & 0.38 & 0.46 & 0.64 & 0.90 & 0.53 & 0.38 \\
\hline Daily feed intake, $g$ & 146 & 144 & 144 & 144 & 147 & 144 & 146 & 148 & 144 & 142 & 145 & 0.90 & 1.09 & 1.53 & 0.12 & 0.13 & 0.51 \\
\hline $\begin{array}{l}\text { Feed conversion } \\
\text { ratio, } \mathrm{g} / \mathrm{g}\end{array}$ & 2.56 & 2.52 & 2.52 & 2.54 & 2.55 & 2.52 & 2.55 & 2.59 & 2.52 & 2.52 & 2.51 & 0.01 & 0.01 & 0.02 & $<0.05$ & 0.28 & 0.08 \\
\hline
\end{tabular}

*SEM: Standard Error of Means ( $\mathrm{n}=36$ animals/treatment).

** Low: 3.5\% ADL; Medium: 4.5\% ADL; High: 5.5\% ADL. 
Table 21. Effect of lignin source and level on zootechnical parameters in rabbits from 35 to $61 \mathrm{~d}$ of age, breed in collective cages. (Experiment 3)

\begin{tabular}{|c|c|c|c|c|c|c|c|c|c|c|c|c|c|c|c|c|c|}
\hline & \multicolumn{3}{|c|}{$\underline{\text { Source }(\mathrm{S})}$} & \multirow{2}{*}{$\begin{array}{l}\text { Level }(\mathrm{L}) * * \\
\text { Medium } \\
\text { (M) }\end{array}$} & \multirow[b]{2}{*}{$\begin{array}{l}\text { High } \\
(\mathrm{H})\end{array}$} & \multicolumn{3}{|c|}{$\underline{\operatorname{Arbocel}^{\circledR}(\mathrm{A})}$} & \multicolumn{3}{|c|}{$\begin{array}{c}\text { Defatted Grape Seed } \\
\text { Meal (G) }\end{array}$} & \multicolumn{3}{|c|}{$\underline{\text { SEM}^{*}}$} & \multicolumn{3}{|c|}{$\underline{P \text {-value }}$} \\
\hline & $\mathrm{A}$ & G & $\begin{array}{l}\text { Low } \\
(\mathrm{L})\end{array}$ & & & $\mathrm{L}$ & M & $\mathrm{H}$ & $\mathrm{L}$ & M & $\mathrm{H}$ & S & $\mathrm{L}$ & SxL & $\mathrm{S}$ & $\mathrm{L}$ & SxL \\
\hline Weight at $35 \mathrm{~d}, \mathrm{~g}$ & 832 & 854 & 842 & 836 & 851 & 839 & 821 & 838 & 845 & 851 & 865 & 9.22 & 11.3 & 16.0 & 0.10 & 0.61 & 0.72 \\
\hline Weight at $60 \mathrm{~d}, \mathrm{~g}$ & 2199 & 2204 & 2202 & 2201 & 2200 & 2200 & 2202 & 2194 & 2205 & 2201 & 2205 & 6.73 & 8.21 & 11.6 & 0.60 & 0.97 & 0.85 \\
\hline Daily weight gain, $\mathrm{g}$ & 52.1 & 52.3 & 52.3 & 52.2 & 52.2 & 52.2 & 52.3 & 52.0 & 52.4 & 52.2 & 52.4 & 0.26 & 0.32 & 0.45 & 0.60 & 0.98 & 0.85 \\
\hline Daily feed intake, g & 140 & 139 & 138 & 139 & 141 & 138 & 141 & 142 & 139 & 138 & 140 & 0.66 & 0.80 & 1.14 & 0.13 & 0.11 & 0.13 \\
\hline $\begin{array}{l}\text { Feed conversion } \\
\text { ratio, } \mathrm{g} / \mathrm{g}\end{array}$ & 2.69 & 2.65 & $2.65^{b}$ & $2.67^{b}$ & $2.70^{a}$ & $2.64^{a}$ & $2.70^{b c}$ & $2.73^{c}$ & $2.65^{a}$ & $2.64^{a}$ & $2.66^{a b}$ & 0.01 & 0.01 & 0.01 & $<0.05$ & $<0.05$ & $<0.05$ \\
\hline Mortality, \% & 1.39 & 2.22 & 0.83 & 2.92 & 1.67 & 0.83 & 1.67 & 1.67 & 0.83 & 4.17 & 1.67 & - & - & - & 0.63 & 0.36 & 0.73 \\
\hline
\end{tabular}

*SEM: Standard Error of Means ( $\mathrm{n}=24$ cages/treatment).

a-c Values within a row with different superscripts differ significantly at $\mathrm{P}<0.05$.

** Low: 3.5\% ADL; Medium: 4.5\% ADL; High: 5.5\% ADL). 
Table 22. Effect of lignin source and level on slaughter traits at 62 d. (Experiment 3)

\begin{tabular}{|c|c|c|c|c|c|c|c|c|c|c|c|c|c|c|c|c|c|}
\hline & \multicolumn{2}{|c|}{$\underline{\text { Source }(\mathrm{S})}$} & \multicolumn{3}{|c|}{$\underline{\text { Level }(\mathrm{L})^{* *}}$} & \multicolumn{3}{|c|}{$\operatorname{Arbocel}^{\circledR}(\mathrm{A})$} & \multicolumn{3}{|c|}{$\begin{array}{l}\text { Defatted Grape Seed } \\
\text { Meal (G) }\end{array}$} & \multicolumn{3}{|c|}{$\underline{\text { SEM }^{*}}$} & \multicolumn{3}{|c|}{$\underline{P \text {-value }}$} \\
\hline & A & G & $\begin{array}{l}\text { Low } \\
(\mathrm{L})\end{array}$ & $\begin{array}{l}\text { Medium } \\
\text { (M) }\end{array}$ & $\begin{array}{l}\text { High } \\
(\mathrm{H})\end{array}$ & $\mathrm{L}$ & M & $\mathrm{H}$ & $\mathrm{L}$ & M & $\mathrm{H}$ & S & $\mathrm{L}$ & SxL & $\mathrm{S}$ & $\mathrm{L}$ & SxL \\
\hline $\begin{array}{l}\text { Body weight at } \\
\text { slaughter, g }\end{array}$ & 2513 & 2515 & $2521^{a}$ & $2486^{b}$ & $2536^{a}$ & 2515 & 2471 & 2554 & 2527 & 2502 & 2518 & 9.79 & 11.2 & 16.9 & 0.87 & $<0.05$ & 0.11 \\
\hline $\begin{array}{l}\text { Cold carcass } \\
\text { weight, } g\end{array}$ & 1462 & 1465 & $1471^{a}$ & $1447^{b}$ & $1473^{a}$ & 1466 & 1437 & 1482 & 1475 & 1457 & 1464 & 6.15 & 7.02 & 10.6 & 0.69 & $<0.05$ & 0.15 \\
\hline Carcass Yield, \% & 58.2 & 58.2 & 58.3 & 58.2 & 58.1 & 58.3 & 58.1 & 58.1 & 58.4 & 58.2 & 58.1 & 0.12 & 0.14 & 0.21 & 0.61 & 0.49 & 1.00 \\
\hline $\begin{array}{l}\text { Digestive tract } \\
\text { weight, } \% \mathrm{BW}^{\#}\end{array}$ & 17.7 & 17.5 & $17.9^{a}$ & $17.4^{b}$ & $175^{b}$ & 17.9 & 17.3 & 17.7 & 17.8 & 17.6 & 17.2 & 0.11 & 0.14 & 0.19 & 0.37 & 0.05 & 0.12 \\
\hline $\begin{array}{l}\text { Full stomach } \\
\text { weight, \%BW }\end{array}$ & 4.16 & 4.12 & 4.23 & 4.20 & 3.99 & 4.26 & 4.07 & 4.14 & 4.20 & 4.33 & 3.83 & 0.09 & 0.11 & 0.15 & 0.77 & 0.18 & 0.14 \\
\hline $\begin{array}{l}\text { Empty stomach } \\
\text { weight, \%BW }\end{array}$ & 0.93 & 0.93 & 0.93 & 0.94 & 0.91 & 0.93 & 0.95 & 0.90 & 0.93 & 0.92 & 0.92 & 0.01 & 0.01 & 0.02 & 0.89 & 0.20 & 0.25 \\
\hline $\begin{array}{l}\text { Full caecal } \\
\text { weight, \%BW }\end{array}$ & 6.38 & 6.21 & $6.63^{a}$ & $6.16^{b}$ & $6.09^{b}$ & 6.66 & 6.34 & 6.13 & 6.60 & 5.98 & 6.04 & 0.08 & 0.10 & 0.14 & 0.14 & $<0.05$ & 0.49 \\
\hline
\end{tabular}

*SEM: Standard Error of Means ( $\mathrm{n}=24$ animals/treatment).

** Low: 3.5\% ADL; Medium: 4.5\% ADL; High: 5.5\% ADL).

\# BW: Body Weight.

a,b Values within a row with different superscripts differ significantly at $P<0.05$. 
Table 23. Effect of lignin source and level on apparent total-tract digestibility (ATTD) from 53 to 57 d. (Experiment 3)

\begin{tabular}{|c|c|c|c|c|c|c|c|c|c|c|c|c|c|c|c|c|c|}
\hline & \multicolumn{2}{|c|}{$\underline{\text { Source }(\mathrm{S})}$} & \multicolumn{3}{|c|}{$\underline{\text { Level }(\mathrm{L}) * *}$} & \multicolumn{3}{|c|}{ Arbocel $^{\circledR}(\mathrm{A})$} & \multicolumn{3}{|c|}{$\begin{array}{c}\text { Defatted Grape Seed } \\
\text { Meal (G) }\end{array}$} & \multicolumn{3}{|c|}{$\underline{\text { SEM }^{*}}$} & \multicolumn{3}{|c|}{$\underline{P \text {-value }}$} \\
\hline & A & $\underline{G}$ & $\begin{array}{c}\text { Low } \\
(\mathrm{L})\end{array}$ & $\begin{array}{l}\text { Medium } \\
(\mathrm{M})\end{array}$ & $\begin{array}{c}\text { High } \\
(\mathrm{H})\end{array}$ & $\mathrm{L}$ & M & $\mathrm{H}$ & $\mathrm{L}$ & $\mathrm{M}$ & $\mathrm{H}$ & $S$ & $\mathrm{~L}$ & SxL & $S$ & $\mathrm{~L}$ & SxL \\
\hline $\begin{array}{l}\text { Dry matter } \\
\text { intake, } g / d\end{array}$ & 164 & 164 & 165 & 164 & 163 & 163 & 165 & 165 & 166 & 164 & 162 & 2.49 & 3.06 & 4.31 & 0.98 & 0.95 & 0.77 \\
\hline \multicolumn{18}{|c|}{ Digestibility coefficients, $\%$} \\
\hline Dry matter & 56.9 & 57.7 & $58.3^{a}$ & $56.8^{b}$ & $56.7^{b}$ & 58.4 & 56.3 & 56.0 & 58.2 & 57.3 & 57.5 & 0.27 & 0.33 & 0.47 & $<0.05$ & $<0.05$ & 0.22 \\
\hline Organic matter & 58.8 & 59.7 & $60.2^{a}$ & $58.7^{b}$ & $58.9^{b}$ & 60.3 & 58.2 & 58.0 & 60.1 & 59.3 & 59.7 & 0.26 & 0.32 & 0.45 & $<0.05$ & $<0.05$ & 0.11 \\
\hline Crude protein & 71.3 & 71.2 & 72.6 & 70.1 & 71.0 & 72.6 & 69.4 & 71.9 & 72.5 & 70.9 & 70.2 & 0.56 & 0.69 & 0.97 & 0.94 & 0.05 & 0.23 \\
\hline Gross energy & 59.0 & 59.7 & $60.2^{a}$ & $58.8^{b}$ & $59.0^{b}$ & 60.3 & 58.4 & 58.4 & 60.2 & 59.2 & 59.6 & 0.28 & 0.34 & 0.48 & 0.09 & $<0.05$ & 0.38 \\
\hline $\begin{array}{l}\text { Neutral } \\
\text { detergent fibre }\end{array}$ & 18.9 & 18.4 & 19.6 & 18.5 & 17.7 & 19.9 & 19.1 & 17.5 & 19.3 & 17.9 & 18.0 & 0.55 & 0.68 & 0.96 & 0.55 & 0.16 & 0.68 \\
\hline Ether extract & 86.3 & 86.0 & $84.7^{\mathbf{b}}$ & $85.8^{b}$ & $88.0^{a}$ & $84.7^{d}$ & $85.1^{c d}$ & $89.2^{a}$ & $84.6^{d}$ & $86.6^{b c}$ & $86.8^{b}$ & 0.32 & 0.41 & 0.58 & 0.48 & $<0.001$ & $<0.05$ \\
\hline
\end{tabular}

\footnotetext{
*SEM: Standard Error of Means ( $\mathrm{n}=11$ animals/treatment).

** Low: 3.5\% ADL; Medium: 4.5\% ADL; High: 5.5\% ADL).

a-d Values within a row with different superscripts differ significantly at $P<0.05$.
} 


\subsubsection{Carcass chemical composition and nitrogen and energy balances}

Carcass chemical composition was not affected by the enzymatic complex supplementation (Table 24).

Any of the parameters evaluated for the nitrogen balance were affected $(\mathrm{P}>0,05)$ by the treatments (Table 25), except energy balance that showed a significant $(\mathrm{P}<0.05)$ linear decrease on digestible energy intake and an increase in the energy excreted in the faeces (Table 26). 
Table 24. Effect of lignin source and level on carcass chemical composition at 34 and $60 \mathrm{~d}$. (Experiment 3)

\begin{tabular}{|c|c|c|c|c|c|c|c|c|c|c|c|c|c|c|c|c|c|}
\hline & \multicolumn{2}{|c|}{$\underline{\text { Source }(\mathrm{S})}$} & \multirow[b]{2}{*}{$\begin{array}{l}\text { Low } \\
\text { (L) }\end{array}$} & \multirow{2}{*}{$\begin{array}{l}\text { Level }(\mathrm{L}) * * \\
\text { Medium } \\
\text { (M) }\end{array}$} & \multirow[b]{2}{*}{$\begin{array}{l}\text { High } \\
(\mathrm{H})\end{array}$} & \multicolumn{3}{|c|}{$\underline{\operatorname{Arbocel}^{\circledR}(\mathrm{A})}$} & \multicolumn{3}{|c|}{$\begin{array}{c}\text { Defatted Grape Seed } \\
\text { Meal (G) }\end{array}$} & \multicolumn{3}{|c|}{$\underline{\text { SEM* }^{*}}$} & \multicolumn{3}{|c|}{$\underline{P \text {-value }}$} \\
\hline & A & G & & & & $\mathrm{L}$ & M & $\mathrm{H}$ & $\mathrm{L}$ & M & $\mathrm{H}$ & $\mathrm{S}$ & $\mathrm{L}$ & SxL & $\mathrm{S}$ & $\mathrm{L}$ & SxL \\
\hline \multicolumn{18}{|c|}{ Carcass composition at $34 \mathrm{~d}$ of age, \% DM } \\
\hline Body weight, g & 942 & 931 & 952 & 919 & 938 & 971 & 914 & 940 & 933 & 923 & 937 & 17.3 & 21.2 & 29.9 & 0.66 & 0.54 & 0.74 \\
\hline Water, \% & 71.9 & 71.8 & 71.9 & 71.9 & 71.8 & 71.9 & 72.0 & 71.9 & 71.9 & 71.8 & 71.8 & 0.07 & 0.08 & 0.12 & 0.42 & 0.77 & 0.76 \\
\hline Crude Protein & 60.3 & 60.0 & 60.4 & 60.2 & 59.9 & 60.4 & 60.5 & 60.1 & 60.4 & 59.8 & 59.7 & 0.28 & 0.34 & 0.48 & 0.36 & 0.57 & 0.77 \\
\hline Ash & 17.3 & 17.4 & 17.4 & 17.4 & 17.4 & 17.4 & 17.3 & 17.3 & 17.4 & 17.4 & 17.4 & 0.12 & 0.15 & 0.21 & 0.53 & 1.00 & 0.97 \\
\hline Ether extract & 18.2 & 18.5 & 17.8 & 18.5 & 18.7 & 17.6 & 18.3 & 18.7 & 18.0 & 18.7 & 18.8 & 0.26 & 0.32 & 0.45 & 0.36 & 0.11 & 0.91 \\
\hline $\begin{array}{l}\text { Gross Energy, } \\
\text { kJ/100 g DM }\end{array}$ & 1867 & 1874 & 1864 & 1872 & 1875 & 1861 & 1864 & 1876 & 1868 & 1880 & 1874 & 6.11 & 7.48 & 10.6 & 0.43 & 0.60 & 0.70 \\
\hline \multicolumn{18}{|c|}{ Carcass composition at $60 \mathrm{~d}$ of age, \% DM } \\
\hline Body weight, g & 2426 & 2407 & 2440 & 2384 & 2425 & 2446 & 2403 & 2427 & 2434 & 2364 & 2422 & 19.5 & 23.9 & 33.7 & 0.49 & 0.23 & 0.86 \\
\hline Water, \% & 65.5 & 65.6 & 65.4 & 65.8 & 65.6 & 65.2 & 65.8 & 65.6 & 65.5 & 65.8 & 65.6 & 0.14 & 0.17 & 0.24 & 0.55 & 0.23 & 0.75 \\
\hline Crude Protein & 50.2 & 50.8 & 50.0 & 50.9 & 50.5 & 49.4 & 50.8 & 50.4 & 50.6 & 51.1 & 50.7 & 0.44 & 0.54 & 0.76 & 0.37 & 0.49 & 0.81 \\
\hline Ash & 13.5 & 13.2 & 13.4 & 13.4 & 13.2 & 18.0 & 18.0 & 18.0 & 18.1 & 18.2 & 17.8 & 0.11 & 0.13 & 0.14 & 0.09 & 0.53 & 0.35 \\
\hline Ether extract & 35.3 & 35.6 & 35.9 & 34.9 & 35.5 & 36.4 & 34.7 & 34.8 & 35.4 & 35.1 & 36.3 & 0.49 & 0.61 & 0.85 & 0.68 & 0.51 & 0.35 \\
\hline $\begin{array}{l}\text { Gross Energy, } \\
\text { kJ/100 g DM }\end{array}$ & 2236 & 2254 & 2258 & 2235 & 2243 & 2267 & 2220 & 2221 & 2249 & 2249 & 2266 & 11.0 & 13.5 & 19.0 & 0.25 & 0.47 & 0.24 \\
\hline
\end{tabular}


Table 25. Effect of lignin source and level on nitrogen and balance from 34 to $60 \mathrm{~d}$. (Experiment 3)

\begin{tabular}{|c|c|c|c|c|c|c|c|c|c|c|c|c|c|c|c|c|c|}
\hline & \multicolumn{2}{|c|}{$\underline{\text { Source }(\mathrm{S})}$} & \multicolumn{3}{|c|}{ Level (L)** } & \multicolumn{3}{|c|}{ Arbocel $^{\circledR}$} & \multicolumn{3}{|c|}{$\begin{array}{c}\text { Defatted Grape Seed } \\
\underline{\text { Meal }(\mathrm{G})}\end{array}$} & \multicolumn{3}{|c|}{$\underline{\text { SEM}^{*}}$} & \multicolumn{3}{|c|}{$\underline{P \text {-value }}$} \\
\hline & A & G & $\begin{array}{c}\text { Low } \\
(\mathrm{L})\end{array}$ & $\begin{array}{l}\text { Medium } \\
(\mathrm{M})\end{array}$ & $\begin{array}{l}\text { High } \\
(\mathrm{H})\end{array}$ & $\mathrm{L}$ & M & $\mathrm{H}$ & $\mathrm{L}$ & $\mathrm{M}$ & $\mathrm{H}$ & $\mathrm{S}$ & $\mathrm{L}$ & SxL & $\mathrm{S}$ & $\mathrm{L}$ & SxL \\
\hline \multicolumn{18}{|c|}{ Nitrogen intake ${ }^{\#}, \mathrm{~g} / \mathrm{kg} \mathrm{BW}^{0.75} . \mathrm{d}^{\#}$} \\
\hline $\mathrm{Ni}$ & 2.776 & 2.729 & 2.805 & 2.747 & 2.706 & 2.786 & 2.784 & 2.758 & 2.823 & 2.710 & 2.653 & 0.029 & 0.035 & 0.050 & 0.255 & 0.139 & 0.319 \\
\hline $\mathrm{DNi}$ & 1.990 & 1.934 & $2.025^{\mathrm{a}}$ & $1.959^{\mathrm{ab}}$ & $1.901^{\mathrm{b}}$ & 2.013 & 1.995 & 1.961 & 2.038 & 1.923 & 1.840 & 0.025 & 0.031 & 0.044 & 0.125 & $<0.05$ & 0.236 \\
\hline \multicolumn{18}{|c|}{ Nitrogen retained ${ }^{\#}, \mathrm{~g} / \mathrm{kg} \mathrm{BW}^{0.75} \cdot \mathrm{d}^{\#}$} \\
\hline NR body & 1.038 & 1.026 & 1.022 & 1.052 & 1.022 & 1.003 & 1.078 & 1.034 & 1.041 & 1.027 & 1.010 & 0.018 & 0.022 & 0.030 & 0.623 & 0.541 & 0.327 \\
\hline NR carcass & 0.666 & 0.671 & 0.666 & 0.680 & 0.660 & 0.656 & 0.676 & 0.667 & 0.676 & 0.683 & 0.653 & 0.012 & 0.015 & 0.020 & 0.788 & 0.626 & 0.714 \\
\hline \multicolumn{18}{|c|}{ Nitrogen efficiency } \\
\hline NR body/DNi & 0.523 & 0.532 & $0.506^{\mathrm{b}}$ & $0.537 \mathrm{a}$ & $0.539^{\mathrm{a}}$ & 0.500 & 0.541 & 0.528 & 0.512 & 0.533 & 0.550 & 0.007 & 0.008 & 0.012 & 0.370 & $<0.05$ & 0.459 \\
\hline $\mathrm{NR}$ carcass/DNi & 0.335 & 0.348 & 0.328 & 0.347 & 0.348 & 0.326 & 0.339 & 0.340 & 0.331 & 0.355 & 0.357 & 0.005 & 0.007 & 0.009 & 0.108 & 0.070 & 0.791 \\
\hline \multicolumn{18}{|c|}{ Nitrogen losses, $\mathrm{g} / \mathrm{kg} \mathrm{BW}$ B.75.d } \\
\hline Skin and viscera & 0.374 & 0.356 & 0.359 & 0.372 & 0.363 & .350 & 0.401 & 0.370 & 0.368 & 0.343 & 0.357 & 0.011 & 0.014 & 0.020 & 0.273 & 0.788 & 0.167 \\
\hline Faeces & 0.786 & 0.794 & 0.777 & 0.788 & 0.806 & 0.770 & 0.790 & 0.799 & 0.783 & 0.787 & 0.813 & 0.017 & 0.021 & 0.029 & 0.733 & 0.590 & 0.945 \\
\hline Urine & 0.952 & 0.908 & $1.003^{\mathrm{a}}$ & $0.909^{\mathrm{b}}$ & $0.878^{\mathrm{b}}$ & 1.010 & 0.920 & 0.927 & 0.996 & 0.898 & 0.830 & 0.020 & 0.024 & 0.034 & 0.123 & $<0.05$ & 0.423 \\
\hline
\end{tabular}

** Low: 3.5\% ADL; Medium: 4.5\% ADL; High: 5.5\% ADL).

a,b Values within a row with different superscripts differ significantly at $P<0.05$.

\#Ni: nitrogen intake. DNi: digestible nitrogen intake. NR: nitrogen retained. Skin and viscera $\left(\mathrm{g} / \mathrm{kg} \mathrm{BW}{ }^{0.75}\right.$ and d): (g N retained in body $\mathrm{g}$ retained in carcass) $/ \mathrm{g} \mathrm{BW}^{0.75}$ and d. Faeces $\left(\mathrm{g} / \mathrm{kg} \mathrm{BW}^{0.75}\right.$ and d): (Total N intake $\left.-\mathrm{DNi}\right) / \mathrm{kg} \mathrm{BW}^{0.75}$ and d. Urine $\left(\mathrm{g} / \mathrm{kg} \mathrm{BW}^{0.75}\right.$ and d):

$\left(\mathrm{DNi}-\mathrm{N}\right.$ Retained in carcass $-\mathrm{N}$ excreted in skin and viscera) $/ \mathrm{kg} \mathrm{BW}^{0.75}$ and $\mathrm{d}$. 
Table 26. Effect of lignin source and level on energy balance from 34 to $60 \mathrm{~d}$. (Experiment 3)

\begin{tabular}{|c|c|c|c|c|c|c|c|c|c|c|c|c|c|c|c|c|c|}
\hline & \multicolumn{2}{|c|}{$\underline{\text { Source }(\mathrm{S})}$} & \multicolumn{2}{|r|}{$\underline{\text { Level }(\mathrm{L}) * *}$} & \multicolumn{4}{|c|}{$\underline{\text { Arbocel }^{\circledR}}$} & \multicolumn{3}{|c|}{$\frac{\text { Defatted Grape Seed }}{\underline{\text { Meal }(\mathrm{G})}}$} & \multicolumn{3}{|c|}{$\underline{\text { SEM }^{*}}$} & \multicolumn{3}{|c|}{$\underline{P \text {-value }}$} \\
\hline & A & G & $\begin{array}{l}\text { Low } \\
\text { (L) }\end{array}$ & $\begin{array}{l}\text { Medium } \\
\text { (M) }\end{array}$ & $\begin{array}{l}\text { High } \\
(\mathrm{H})\end{array}$ & $\mathrm{L}$ & $\mathrm{M}$ & $\mathrm{H}$ & $\mathrm{L}$ & M & $\mathrm{H}$ & $\mathrm{S}$ & $\mathrm{L}$ & SxL & $S$ & $\mathrm{~L}$ & SxL \\
\hline \multicolumn{18}{|c|}{ Energy intake ${ }^{\#}, \mathrm{MJ} / \mathrm{kg} \mathrm{BW}^{0.75} . \mathrm{d}$} \\
\hline GEi & 1.784 & 1.769 & 1.768 & 1.800 & 1.762 & 1.756 & 1.823 & 1.774 & 1.780 & 1.777 & 1.750 & 0.019 & 0.900 & 0.032 & 0.563 & 0.476 & 0.533 \\
\hline $\mathrm{DEi}$ & 1.055 & 1.053 & 1.071 & 1.053 & 1.039 & 1.066 & 1.060 & 1.039 & 1.076 & 1.045 & 1.038 & 0.014 & 0.535 & 0.024 & 0.924 & 0.409 & 0.876 \\
\hline \multicolumn{18}{|c|}{ Energy retained $^{\#}, \mathrm{~kJ} / \mathrm{kg} \mathrm{BW}^{0.75} . \mathrm{d}$} \\
\hline ER body & 398.8 & 396.4 & 396.9 & 403.1 & 392.9 & 387.7 & 410.7 & 397.9 & 406.1 & 395.4 & 387.8 & 7.969 & 9.763 & 13.76 & 0.835 & 0.768 & 0.419 \\
\hline ER carcass & 236.5 & 239.5 & 240.7 & 239.2 & 234.1 & 236.6 & 236.7 & 236.1 & 244.8 & 241.6 & 232.1 & 4.679 & 5.733 & 8.081 & 0.649 & 0.696 & 0.740 \\
\hline \multicolumn{18}{|c|}{ Energy efficiency } \\
\hline $\begin{array}{l}\text { ER } \\
\text { body/DEi }\end{array}$ & 0.399 & 0.397 & 0.398 & 0.403 & 0.393 & 0.389 & 0.411 & 0.397 & 0.408 & 0.395 & 0.388 & 0.008 & 0.010 & 0.014 & 0.873 & 0.748 & 0.393 \\
\hline $\begin{array}{l}\text { ER } \\
\text { carcass/DEi }\end{array}$ & 0.238 & 0.240 & 0.242 & 0.239 & 0.236 & 0.239 & 0.238 & 0.238 & 0.246 & 0.240 & 0.233 & 0.005 & 0.006 & 0.008 & 0.801 & 0.720 & 0.774 \\
\hline \multicolumn{18}{|c|}{ Energy losses, MJ/kg BW ${ }^{0.75}$.d } \\
\hline $\begin{array}{l}\text { Skin and } \\
\text { viscera }\end{array}$ & 0.163 & 0.157 & 0.156 & 0.164 & 0.160 & 0.150 & 0.175 & 0.163 & 0.162 & 0.153 & 0.157 & 0.005 & 0.006 & 0.008 & 0.409 & 0.595 & 0.108 \\
\hline Faeces & 0.731 & 0.716 & $0.699^{b}$ & $0.745^{\mathrm{a}}$ & $0.726^{\mathrm{ab}}$ & 0.693 & 0.763 & 0.738 & 0.706 & 0.727 & 0.715 & 0.009 & 0.011 & 0.016 & 0.242 & $<0.05$ & 0.284 \\
\hline $\begin{array}{l}\text { Urine + } \\
\text { heat } \\
\text { production }\end{array}$ & 0.654 & 0.656 & 0.672 & 0.650 & 0.644 & 0.676 & 0.648 & 0.638 & 0.668 & 0.652 & 0.650 & 0.011 & 0.013 & 0.019 & 0.856 & 0.293 & 0.861 \\
\hline $\begin{array}{l}* * \text { Standa } \\
* * \text { Low: } \\
\text { a,b Values } \\
\text { GEi: gros } \\
\text { Skin and } \\
\text { Faeces (N }\end{array}$ & $\begin{array}{l}\text { Error } \\
6 \text { AD } \\
\text { hin a } \\
\text { ergy } \\
\text { era ( } \\
\text { g BW }\end{array}$ & $\begin{array}{l}\text { Mean } \\
\text { Medil } \\
\text { w witl } \\
\text { ake. I } \\
/ \mathrm{kg} \mathrm{B} \\
5 \text { and }\end{array}$ & $\begin{array}{l}1=11 \\
: 4.59 \\
\text { iffere } \\
: \text { dige } \\
75 \text { an } \\
\text { (Gro }\end{array}$ & $\begin{array}{l}\text { imals/tre } \\
\text { DL; Hig } \\
\text { uperscrip } \\
\text { le energ } \\
\text { : (MJ gro } \\
\text { inergy in }\end{array}$ & $\begin{array}{l}\text { ment). } \\
5.5 \% \text { A } \\
\text { differ s } \\
\text { ntake. I } \\
\text { energy } \\
\text { ke -DEi }\end{array}$ & $\begin{array}{l}\text { L). } \\
\text { nific } \\
\text { : en } \\
\text { etain }\end{array}$ & $\begin{array}{l}\text { ly a } \\
\text { y re } \\
\text { in - } \\
.75 \text { at }\end{array}$ & $\begin{array}{l}0.05 . \\
\text { ed. } \\
\text { gross } \\
\text { t. }\end{array}$ & erg & tai & $\mathrm{c}$ & s) $/ \mathrm{k}$ & $J^{0.75}$ & d. & & & \\
\hline
\end{tabular}




\subsection{Experiment 4: Effect of feed restriction on growth performance, carcass yield and nitrogen and energy balance in growing rabbits.}

\subsubsection{Growth performance}

Mortality in the whole fattening period was similar among treatments $(12.8 \%$ on average) and any restriction strategy reduced it (Table 27). The observed symptoms were liquid stomach, and intestinal distension with gas and mucus, which were compatible with epizootic rabbit enteropathy.

During the first fattening phase (from 34 to $48 \mathrm{~d}$ ), 80 and $70 \%$ of restriction from $a d$ libitum feed intake, decreased the growth performance (DWG) $(-24.5$ and $-34.7 \%$, respectively; $\mathrm{P}<0.001)$ and impaired the feed conversion ratio (FCR) $(+5.2$ and $+6.7 \%$, respectively; $\mathrm{P}<0.001)$.

In the second fattening phase (from 48 to $61 \mathrm{~d}$ ), there was a compensatory growth in the animals re-fed ad libitum $(\mathrm{R} 80 \mathrm{AL}=+26.5 \%$ and $\mathrm{R} 70 \mathrm{AL}=+34.8 \%$, with respect $\mathrm{AL} ; \mathrm{P}<$ 0.001). On the opposite, animals that continued restricted during the second period (R80 and R70) did not show significant differences on DWG with the control group, although the rabbits with the highest feed restriction (R70) had the lowest DWG (43.8 $\mathrm{g} / \mathrm{d}$ ), with respect to the other treatments.

During this period, an interaction between feeding program and restriction level was found $(\mathrm{P}<0.001)$. Feed intake in R80AL and R70AL groups were similar $(158 \mathrm{~g} / \mathrm{d}$, on average), but higher $(+7.5 \%, \mathrm{P}<0.001)$ than in the control group, whereas feed intake in R80 and R70 were lower than in control group ( -8.2 and $-19.0 \%$, respectively), especially in R70 treatment. Nevertheless, because the increase of feed intake (DFI) was lower than the DWG, 
R80AL and R70AL treatments improved the FCR with respect the animals fed ad libitum (+15.8 and $+20.2 \%$ for R80AL and R70AL, respectively; $\mathrm{P}<0.001)$. The same effect was observed for treatments R80 and R70, which also improved FCR with respect AL group (+12.0 and $+13.9 \%$, respectively; $\mathrm{P}<0.001$ ), despite the fact that there was no compensatory growth in the R70 group with respect to AL group.

Rabbits restricted at $80 \%$ and later ad libitum (R80AL) achieved a body weight and a DWG like non-restricted animals. However, the animals restricted up to $70 \%$ only during the first fattening period (R70AL), were not able to match, neither the weight $(-5.2 \%)$ nor the DWG (-7.2\%) than AL. The rabbits of the treatments R80 and R70 showed, as it was expected, a lower body weight $(-9.1$ and $-14.9 \%$, respectively) than the animals fed ad libitum. Moreover, FCR was lower in the restricted animals, but only R80AL and R70AL were significantly different from the control (+4 and $+5 \%$, respectively; $\mathrm{P}<0.001)$.

\subsubsection{Slaughter traits}

Despite the carcass yield of restricted treatments was similar to that of the animals fed ad libitum, it tended to be different $(\mathrm{P}=0.075$; Table 28) between $\mathrm{R} 70$ and R80AL, being the lowest (54.2\%) and the highest (55.6\%) value, respectively.

Relative digestive tract weight of all restricted groups was similar to the control group. It only differed in those treatments refed ad libitum $(19.3$ and $20.6 \% \mathrm{BW}$ for R80AL and R70AL, respectively; $\mathrm{P}=0.034)$. Relative liver weight was higher in $\mathrm{R} 80 \mathrm{AL}$ with respect AL $(+11.3 \%)$. On the other hand, R70 showed the lowest liver weight of all treatments (3.51\%BW), being 20\% lower than the AL group. R80 and R70AL had similar relative liver weights than the AL treatment. Relative full stomach weight was heavier in rabbits refed ad 
libitum than in the rest of treatments $(+15.2 \%$; $\mathrm{P}<0.001)$, but the weight of the empty stomach was higher in all restricted animals compared with the control ones $(+8.62 \%$; $<<0.001)$. There were no differences in the caecal weight among treatments $(\mathrm{P}=0.25)$.

\subsubsection{Apparent total-tract digestibility (ATTD)}

The different restriction strategies did not affect the nutrient digestibility (Table 29), except for $\mathrm{CP}$ digestibility $(\mathrm{P}=0.017)$, which were 2.5 percentage units higher in animals restricted during the whole fattening period (R80 and R70) than those restricted $80 \%$ up to 48 d R80AL), while AL and R70AL groups showed intermediate values. 
Table 27. Effect of the feeding restriction strategies on zootechnical parameters in rabbits from 34 to $61 \mathrm{~d}$ of age. (Experiment 4 )

\begin{tabular}{|c|c|c|c|c|c|c|c|}
\hline \multirow[b]{2}{*}{ Item } & \multicolumn{5}{|c|}{ Treatments* } & \multirow[b]{2}{*}{ SEM** } & \multirow[b]{2}{*}{ p-Treatment } \\
\hline & $\mathrm{AL}$ & $\mathrm{R} 80$ & $\mathrm{R} 70$ & R80AL & R70AL & & \\
\hline \multicolumn{8}{|c|}{$1^{\text {st }}$ phase: from 34 to $48 \mathrm{~d}^{* * *}$} \\
\hline Weight at $34 \mathrm{~d}, \mathrm{~g}$ & 670 & 673 & 654 & 678 & 673 & 13.3 & 0.76 \\
\hline Weight at $48 \mathrm{~d}, \mathrm{~g}$ & $1514^{\mathrm{a}}$ & $1310^{\mathrm{b}}$ & $1219^{c}$ & $1315^{\mathrm{b}}$ & $1209^{c}$ & 8.50 & $<0.001$ \\
\hline Daily weight gain, $g$ & $60.3^{\mathrm{a}}$ & $45.5^{\mathrm{b}}$ & $40.3^{c}$ & $45.5^{\mathrm{b}}$ & $38.4^{\mathrm{c}}$ & 0.61 & $<0.001$ \\
\hline Daily feed intake, $g$ & $110^{\mathrm{a}}$ & $86.9^{\mathrm{b}}$ & $77.8^{c}$ & $87.5^{\mathrm{b}}$ & $75.5^{\mathrm{c}}$ & 1.00 & $<0.001$ \\
\hline Feed conversion ratio, $\mathrm{g} / \mathrm{g}$ & $1.82^{\mathrm{b}}$ & $1.91^{\mathrm{a}}$ & $1.93^{\mathrm{a}}$ & $1.93^{\mathrm{a}}$ & $1.97^{\mathrm{a}}$ & 0.01 & $<0.001$ \\
\hline Mortality, \% & 3.33 & 6.67 & 3.33 & 5.83 & 4.17 & 2.07 & 0.66 \\
\hline \multicolumn{8}{|c|}{ 2nd phase: from 48 to $61 \mathrm{~d}^{* * *}$} \\
\hline Weight at $61 \mathrm{~d}, \mathrm{~g}$ & $2122^{\mathrm{a}}$ & $1936^{\mathrm{c}}$ & $1790^{\mathrm{d}}$ & $2085^{\mathrm{ab}}$ & $2019^{\mathrm{bc}}$ & 13.4 & $<0.001$ \\
\hline Daily weight gain, $g$ & $46.8^{\mathrm{cd}}$ & $48.4^{\mathrm{c}}$ & $43.8^{\mathrm{d}}$ & $59.2^{\mathrm{b}}$ & $63.1^{\mathrm{a}}$ & 0.79 & $<0.001$ \\
\hline Daily feed intake****, $\mathrm{g}$ & $147^{\mathrm{b}}$ & $135^{\mathrm{c}}$ & $119^{\mathrm{d}}$ & $157^{\mathrm{a}}$ & $159^{\mathrm{a}}$ & 1.72 & $<0.001$ \\
\hline Feed conversion ratio, $\mathrm{g} / \mathrm{g}$ & $3.16^{\mathrm{a}}$ & $2.78^{\mathrm{b}}$ & $2.72^{b}$ & $2.66^{\mathrm{bc}}$ & $2.52^{c}$ & 0.04 & $<0.001$ \\
\hline Mortality, \% & 6.67 & 5.00 & 10.0 & 11.7 & 7.50 & 2.62 & 0.36 \\
\hline \multicolumn{8}{|c|}{ Whole phase: from 34 to $61 \mathrm{~d}$} \\
\hline Daily weight gain, g & $53.9^{\mathrm{a}}$ & $46.8^{c}$ & $42.1^{\mathrm{d}}$ & $52.1^{\mathrm{a}}$ & $50.0^{\mathrm{b}}$ & 0.49 & $<0.001$ \\
\hline Daily feed intake, $g$ & $127^{\mathrm{a}}$ & $109^{c}$ & $97.1^{\mathrm{d}}$ & $118^{\mathrm{b}}$ & $113^{\mathrm{c}}$ & 1.03 & $<0.001$ \\
\hline Feed conversion ratio, $\mathrm{g} / \mathrm{g}$ & $2.36^{\mathrm{a}}$ & $2.33^{\mathrm{ab}}$ & $2.31^{\mathrm{abc}}$ & $2.27^{\mathrm{bc}}$ & $2.24^{\mathrm{c}}$ & 0.02 & $<0.001$ \\
\hline Mortality, \% & 10.0 & 11.7 & 13.3 & 17.5 & 11.7 & 3.10 & 0.48 \\
\hline
\end{tabular}

$* \mathrm{AL}=\mathrm{Ad}$-libitum; R80 = 80\% of theoretical ad libitum feed intake during whole fattening period; $\mathrm{R} 70=70 \%$ of theoretical ad libitum feed intake during whole fattening period; R80AL $=80 \%$ of theoretical ad libitum feed intake up to $48 \mathrm{~d}$; R70AL $=70 \%$ of theoretical ad libitum feed intake up to $48 \mathrm{~d}$.

** Standard Error of Means ( $\mathrm{n}=24$ cages/treatment).

${ }^{\mathrm{a}-\mathrm{d}}$ Values within a row with different superscripts differ significantly at $\mathrm{P}<0.05$.

$* * *$ P-phase $<0.001$ and P-phase $\mathrm{x}$ treatment $<0.001$ for all variables of the phases $34-48 \mathrm{~d}$ and $48-61 \mathrm{~d}$

**** P-feeding program (AL or R) x level restriction $(70$ or $80 \%)<0.001$ for daily feed intake of phase $48-61 \mathrm{~d}$ 
Table 28. Effect of the feeding restriction strategies on slaughter traits at $61 \mathrm{~d}$. (Experiment 4 )

\begin{tabular}{lccccccc}
\hline & \multicolumn{9}{c}{ Treatments* $^{*}$} & SEM** & $p$-Value \\
\cline { 2 - 6 } Item & $\mathrm{AL}$ & $\mathrm{R} 80$ & $\mathrm{R} 70$ & $\mathrm{R} 80 \mathrm{~A}$ & $\mathrm{R} 70 \mathrm{AL}$ & & \\
\hline Body weight at slaughter, g & $2014^{\mathrm{a}}$ & $2092^{\mathrm{a}}$ & $1970^{\mathrm{b}}$ & $2117^{\mathrm{a}}$ & $2055^{\mathrm{ab}}$ & 26.3 & $<0.001$ \\
Cold carcass weight, g & $1157^{\mathrm{a}}$ & $1147^{\mathrm{a}}$ & $1067^{\mathrm{b}}$ & $1178^{\mathrm{a}}$ & $1121^{\mathrm{ab}}$ & 17.2 & $<0.001$ \\
Carcass Yield, \% & 54.9 & 54.9 & 54.2 & 55.6 & 54.6 & 0.35 & 0.08 \\
Digestive tract weight, \%BW & $19.4^{\mathrm{ab}}$ & $19.6^{\mathrm{ab}}$ & $19.9^{\mathrm{ab}}$ & $19.3^{\mathrm{b}}$ & $20.6^{\mathrm{a}}$ & 0.31 & $<0.05$ \\
Liver weight, \%BW & $3.97^{\mathrm{b}}$ & $4.07^{\mathrm{ab}}$ & $3.51^{\mathrm{c}}$ & $4.42^{\mathrm{a}}$ & $4.37^{\mathrm{ab}}$ & 0.11 & $<0.001$ \\
Full stomach weight, \%BW & $4.99^{\mathrm{bc}}$ & $5.06^{\mathrm{bc}}$ & $4.79^{\mathrm{c}}$ & $5.51^{\mathrm{ab}}$ & $5.90^{\mathrm{a}}$ & 0.15 & $<0.001$ \\
Empty stomach weight, \%BW & $1.06^{\mathrm{c}}$ & $1.15^{\mathrm{ab}}$ & $1.22^{\mathrm{a}}$ & $1.11^{\mathrm{bc}}$ & $1.15^{\mathrm{ab}}$ & 0.02 & $<0.001$ \\
Full caecal weight, \% BW & 7.30 & 7.61 & 7.39 & 6.71 & 7.14 & 0.25 & 0.25 \\
\hline
\end{tabular}

$* \mathrm{AL}=\mathrm{Ad}$-libitum; $\mathrm{R} 80=80 \%$ of theoretical ad libitum feed intake during whole fattening period; $\mathrm{R} 70=70 \%$ of theoretical ad libitum feed intake during whole

fattening period; R80AL $=80 \%$ of theoretical ad libitum feed intake up to $48 \mathrm{~d}$ of life; $\mathrm{R} 70 \mathrm{AL}=70 \%$ of theoretical ad libitum feed intake up to $48 \mathrm{~d}$

$* *$ Standard Error of Means ( $\mathrm{n}=24$ cages/treatment).

\# BW: Body Weight.

${ }^{\mathrm{a}-\mathrm{c}}$ Values within a row with different superscripts differ significantly at $\mathrm{P}<0.05$. 
Table 29. Effect of the feeding restriction strategies on apparent total-tract digestibility (ATTD) from 53 to 57 d. (Experiment 4 )

\begin{tabular}{|c|c|c|c|c|c|c|c|}
\hline \multirow[b]{2}{*}{ Item } & \multicolumn{5}{|c|}{ Treatments* } & \multirow[b]{2}{*}{ SEM** } & \multirow[b]{2}{*}{$p$-Value } \\
\hline & $\mathrm{AL}$ & $\mathrm{R} 80$ & R70 & R80AL & R70AL & & \\
\hline Dry matter intake, $\mathrm{g} / \mathrm{d}$ & $153^{\mathrm{a}}$ & $128^{\mathrm{b}}$ & $111^{\mathrm{b}}$ & $158^{\mathrm{a}}$ & $158^{\mathrm{a}}$ & 4.11 & $<0.001$ \\
\hline Digestibility coefficients, $\%$ & & & & & & & \\
\hline Dry matter & 58.1 & 58.4 & 57.5 & 57.5 & 57.9 & 0.34 & 0.32 \\
\hline Organic matter & 60.1 & 60.3 & 59.6 & 59.5 & 59.7 & 0.33 & 0.42 \\
\hline Crude protein & $68.4^{\mathrm{ab}}$ & $70.3^{\mathrm{a}}$ & $70.3^{\mathrm{a}}$ & $67.8^{\mathrm{b}}$ & $70.0^{\mathrm{ab}}$ & 0.61 & $<0.05$ \\
\hline Gross energy & 59.0 & 60.0 & 59.3 & 59.2 & 59.6 & 0.32 & 0.32 \\
\hline Neutral detergent fibre & 22.3 & 21.6 & 20.3 & 21.1 & 20.8 & 0.71 & 0.39 \\
\hline Ether extract & 88.4 & 88.4 & 88.9 & 88.3 & 86.5 & 0.77 & 0.25 \\
\hline
\end{tabular}

$* \mathrm{AL}=$ Ad-libitum; $\mathrm{R} 80=80 \%$ of theoretical ad libitum feed intake during whole fattening period; $\mathrm{R} 70=70 \%$ of theoretical ad libitum feed intake during whole fattening period; R80AL $=80 \%$ of theoretical ad libitum feed intake up to $48 \mathrm{~d}$; R70AL $=70 \%$ of theoretical ad libitum feed intake up to $48 \mathrm{~d}$

** Standard Error of Means ( $\mathrm{n}=12$ cages/treatment).

${ }^{\mathrm{a}, \mathrm{b}}$ Values within a row with different superscripts differ significantly at $\mathrm{P}<0.05$. 
Table 30. Effect of the feeding restriction strategies on carcass chemical composition at 34 and $61 \mathrm{~d}$. (Experiment 4 )

\begin{tabular}{|c|c|c|c|c|c|c|c|}
\hline \multirow[b]{2}{*}{ Item } & \multicolumn{4}{|c|}{ Treatments* } & \multirow[b]{2}{*}{ R70AL } & \multirow[b]{2}{*}{$\mathrm{SEM}^{* *}$} & \multirow[b]{2}{*}{$P$-Value } \\
\hline & $\mathrm{AL}$ & R80 & $\mathrm{R} 70$ & R80AL & & & \\
\hline \multicolumn{8}{|c|}{ Carcass composition at $34 \mathrm{~d}$ of age, \% DM } \\
\hline Body weight, $g$ & 664 & 675 & 651 & 682 & 666 & 13.5 & 0.56 \\
\hline Water, \% & 71.6 & 71.3 & 71.6 & 71.4 & 71.5 & 0.07 & 0.11 \\
\hline Crude Protein & 60.7 & 60.7 & 60.4 & 60.6 & 60.6 & 0.14 & 0.60 \\
\hline Ash & 17.1 & 16.9 & 17.2 & 16.9 & 17.0 & 0.09 & 0.10 \\
\hline Ether extract & 20.2 & 20.3 & 20.5 & 20.2 & 20.1 & 0.17 & 0.41 \\
\hline Gross Energy' kJ/100 g DM & 2051 & 2066 & 2047 & 2064 & 2053 & 6.36 & 0.15 \\
\hline \multicolumn{8}{|c|}{ Carcass composition at $61 \mathrm{~d}$ of age, \% DM } \\
\hline Body weight, $g$ & $2132^{\mathrm{a}}$ & $2013^{\mathrm{a}}$ & $1860^{\mathrm{b}}$ & $2116^{\mathrm{a}}$ & $2004^{\mathrm{a}}$ & 33.1 & $<0.001$ \\
\hline Water, \% & $66.9^{\mathrm{b}}$ & $67.5^{\mathrm{ab}}$ & $68.2^{\mathrm{a}}$ & $67.1^{\mathrm{b}}$ & $67.5^{\mathrm{b}}$ & 0.14 & $<0.001$ \\
\hline Crude Protein & $56.0^{\mathrm{b}}$ & $57.5^{\mathrm{a}}$ & $58.7^{\mathrm{a}}$ & $56.8^{\mathrm{b}}$ & $57.0^{\mathrm{a}}$ & 0.36 & $<0.001$ \\
\hline Ash & $13.3^{\mathrm{b}}$ & $14.1^{\mathrm{b}}$ & $14.9^{\mathrm{a}}$ & $13.6^{\mathrm{b}}$ & $14.0^{\mathrm{b}}$ & 0.16 & $<0.001$ \\
\hline Ether extract & $29.1^{\mathrm{a}}$ & $27.6^{\mathrm{ab}}$ & $26.1^{\mathrm{b}}$ & $28.5^{\mathrm{a}}$ & $27.8^{\mathrm{a}}$ & 0.31 & $<0.001$ \\
\hline Gross Energy, kJ/100 g DM & $2387^{\mathrm{a}}$ & $2326^{\mathrm{b}}$ & $2266^{\mathrm{c}}$ & $2365^{\mathrm{ab}}$ & $2338^{\mathrm{ab}}$ & 11.1 & $<0.001$ \\
\hline
\end{tabular}

$* \mathrm{AL}=$ Ad-libitum; R80 $=80 \%$ of theoretical ad libitum feed intake during whole fattening period; R70 $=70 \%$ of theoretical ad libitum feed intake during whole fattening period; R80AL $=80 \%$ of theoretical ad libitum feed intake up to $48 \mathrm{~d}$ of life; $\mathrm{R} 70 \mathrm{AL}=70 \%$ of theoretical ad libitum feed intake up to $48 \mathrm{~d}$ of life.

** Standard Error of Means ( $\mathrm{n}=24$ cages/treatment).

${ }^{\mathrm{a}, \mathrm{b}}$ Values within a row with different superscripts differ significantly at $\mathrm{P}<0.05$. 


\subsubsection{Carcass chemical composition and nitrogen and energy balances}

The feed restriction affected the carcass chemical composition (Table 30). Protein content increased in the two restricted groups at $70 \%$ (R70 and R70AL) and in the R80 group $(+4.7 \% ;+1.8 \%$ and $+2.6 \%$, respectively; $\mathrm{P}<0.001)$, while the rabbits restricted $80 \%$ only up to $48 \mathrm{~d}$ (R80AL) had a similar protein content than control group. The ash content increased in rabbits restricted at $70 \%$ during the whole period with respect to the other treatments $(14.9 \%$ vs. $13.7 \%$ on average; $\mathrm{P}<0.001)$. The fat, and therefore the energy of the carcass, decreased in the animals restricted during the whole growth period and more significantly in the group R70 ( $-10 \%$ fat than the control; $\mathrm{P}<0.001)$. On the opposite, this group (R70) showed the highest water content compared with AL, R80AL and R70AL groups.

As it was expected, the lower feed intake (from 34 to $61 \mathrm{~d}$ ) in some of the restriction strategies used affected the DN and DE intake significantly $(\mathrm{P}<0.001$; Table 31). Animals restricted at $70 \%$ during the whole growing period (R70) showed a lower feed intake, both DNi and DEi $(-22 \%$ and $-25 \%$, respectively; $\mathrm{P}<0.001)$, compared with animals fed $a d$ libitum. The rest of the restricted animals (R80, R80AL and R70AL) had a similar DNi and $\mathrm{DEi}$, but they were lower than in the animals fed ad libitum $(-10 \%$ and $-9 \%$ on average, respectively) Restricted animals tended to have a better nitrogen efficiency, both in body $(+3.42 \% ; \mathrm{P}=0.099)$ and carcass $(+4.85 \% ; \mathrm{P}=0.074)$ than $\mathrm{AL}$ group. As a consequence, even though the DNi was lower, the nitrogen retained in the carcass and whole body was similar among the different treatments, with the exception of the animals restricted at $70 \%$ during the whole period (R70) that was on average $5.7 \%$ lower in the carcass and $7.14 \%$ in the body (P $<0.05)$ than in the rest or treatments. In this case, the efficacy of retention did not compensate the lower $\mathrm{DNi}$, despite being also the group with lower $\mathrm{N}$ excretion in skin, viscera, faeces and 
urine $(\mathrm{P}<0.001)$. Nitrogen losses in faeces decreased in all restricted animals with respect to the control $(\mathrm{P}<0.001)$, especially in R80 (-15.1\%), R70 $(-22.4 \%)$ and R70AL $(-14.8 \%)$. Moreover, R70 and R80AL showed the lowest nitrogen losses in urine ( $\mathrm{P}<0.001)$.

The efficiency of ER was not affected by the different feeding restriction strategies, but DEi decreased when voluntary intake was restricted, especially in the rabbits of group R70 that had the lowest value $(-17 \%)$ compared to AL. The effects of restriction strategies on energy losses in skin and viscera and trough the faeces, followed a similar evolution than the observed for the nitrogen excretion. Restricted rabbits also showed lower urine energy + heat increment losses compared with animals fed ad libitum. 
Results

Table 31. Effect of the feeding restriction strategies on nitrogen and energy balance from 34 to $61 \mathrm{~d}$. (Experiment 4)

\begin{tabular}{|c|c|c|c|c|c|c|c|}
\hline \multirow[b]{2}{*}{ Item } & \multicolumn{4}{|c|}{ Treatments* } & \multirow[b]{2}{*}{ R70AL } & \multirow[b]{2}{*}{ SEM** } & \multirow[b]{2}{*}{$P$-Value } \\
\hline & $\mathrm{AL}$ & $\mathrm{R} 80$ & $\mathrm{R} 70$ & R80AL & & & \\
\hline \multicolumn{8}{|c|}{ Nitrogen intake $^{\#}, \mathrm{~g} / \mathrm{kg} \mathrm{BW} \mathbf{W}^{0.75} . \mathrm{d}$} \\
\hline $\mathrm{Ni}$ & $2.529^{\mathrm{a}}$ & $2.271^{\mathrm{c}}$ & $2.116^{\mathrm{d}}$ & $2.351^{b}$ & $2.305^{\mathrm{bc}}$ & 0.019 & $<0.001$ \\
\hline $\mathrm{DNi}$ & $1.730^{\mathrm{a}}$ & $1.593^{\mathrm{b}}$ & $1.496^{\mathrm{c}}$ & $1.595^{\mathrm{b}}$ & $1.625^{\mathrm{b}}$ & 0.013 & $<0.001$ \\
\hline \multicolumn{8}{|c|}{ Nitrogen retained ${ }^{\#}$, g/kg BW $W^{0.75} \cdot \mathrm{d}^{1}$} \\
\hline NR body & $1.101^{\mathrm{a}}$ & $1.027^{\mathrm{ab}}$ & $0.989^{b}$ & $1.083^{\mathrm{a}}$ & $1.049^{\mathrm{ab}}$ & 0.010 & $<0.05$ \\
\hline NR carcass & $0.538^{\mathrm{a}}$ & $0.507^{\mathrm{ab}}$ & $0.490^{\mathrm{b}}$ & $0.531^{\mathrm{a}}$ & $0.518^{\mathrm{ab}}$ & 0.019 & $<0.05$ \\
\hline \multicolumn{8}{|l|}{ Nitrogen efficiency } \\
\hline NR body/DNi & 0.636 & 0.644 & 0.662 & 0.679 & 0.646 & 0.012 & 0.099 \\
\hline NR carcass/DNi & 0.309 & 0.317 & 0.327 & 0.333 & 0.319 & 0.006 & 0.074 \\
\hline \multicolumn{8}{|c|}{ Nitrogen losses, g/kg BW $\mathbf{B W}^{0.75} . \mathrm{d}$} \\
\hline Skin and viscera & $0.563^{\mathrm{a}}$ & $0.520^{\mathrm{ab}}$ & $0.499^{\mathrm{b}}$ & $0.552^{\mathrm{a}}$ & $0.532^{\mathrm{ab}}$ & 0.011 & $<0.001$ \\
\hline Faeces & $0.799^{\mathrm{a}}$ & $0.678^{c}$ & $0.620^{\mathrm{d}}$ & $0.756^{\mathrm{b}}$ & $0.681^{\mathrm{c}}$ & 6 & $<0.001$ \\
\hline Urine & $0.630^{\mathrm{a}}$ & $0.566^{\mathrm{ab}}$ & $0.506^{\mathrm{b}}$ & $0.512^{\mathrm{b}}$ & $0.512^{\mathrm{b}}$ & 0.020 & $<0.001$ \\
\hline \multicolumn{8}{|c|}{ Energy intake $^{\#}, \mathrm{MJ} / \mathrm{kg} \mathrm{BW}^{0.75} . \mathrm{d}$} \\
\hline GEi & $1.760^{\mathrm{a}}$ & $1.586^{\mathrm{c}}$ & $1.477^{\mathrm{d}}$ & $1.645^{\mathrm{b}}$ & $1.609^{\mathrm{bc}}$ & 0.013 & $<0.001$ \\
\hline $\mathrm{DEi}$ & $1.054^{\mathrm{a}}$ & $0.953^{\mathrm{b}}$ & $0.875^{\mathrm{c}}$ & $0.975^{\mathrm{b}}$ & $0.960^{\mathrm{b}}$ & 0.008 & $<0.001$ \\
\hline \multicolumn{8}{|c|}{ Energy retained $^{\#}, \mathrm{~kJ} / \mathrm{kg} \mathrm{BW}^{0.75} . \mathrm{d}$} \\
\hline ER body & $367^{\mathrm{a}}$ & $323^{\mathrm{b}}$ & $295^{\mathrm{b}}$ & $354^{\mathrm{ab}}$ & $327^{\mathrm{b}}$ & 8.410 & $<0.001$ \\
\hline ER carcass & $219^{a}$ & $193^{\mathrm{bc}}$ & $174^{\mathrm{c}}$ & $212^{\mathrm{ab}}$ & $195^{\mathrm{b}}$ & 5.151 & $<0.001$ \\
\hline \multicolumn{8}{|l|}{ Energy efficiency } \\
\hline $\mathrm{ER}$ bc & 0.348 & 0.338 & 0.337 & 0.363 & 0.341 & 0.009 & 0.24 \\
\hline ER carcass/DEi & 0.208 & 0.202 & 0.198 & 0.216 & 0.204 & 0.005 & 0.19 \\
\hline \multicolumn{8}{|c|}{ Energy losses, MJ/kg BW $W^{0.75} . \mathrm{d}$} \\
\hline Skin and viscera & $0.149^{\mathrm{a}}$ & $0.129^{c}$ & $0.122^{c}$ & $0.142^{\mathrm{ab}}$ & $0.132^{\mathrm{bc}}$ & 0.004 & $<0.001$ \\
\hline Faeces & $0.706^{\mathrm{a}}$ & $0.633^{\mathrm{c}}$ & $0.603^{d}$ & $0.670^{\mathrm{b}}$ & $0.649^{\mathrm{bc}}$ & 0.005 & $<0.001$ \\
\hline Urine + heat production & $0.687^{\mathrm{a}}$ & $0.630^{\mathrm{b}}$ & $0.580^{c}$ & $0.621^{\mathrm{bc}}$ & $0.632^{\mathrm{b}}$ & 0.010 & $<0.001$ \\
\hline \multicolumn{8}{|c|}{ 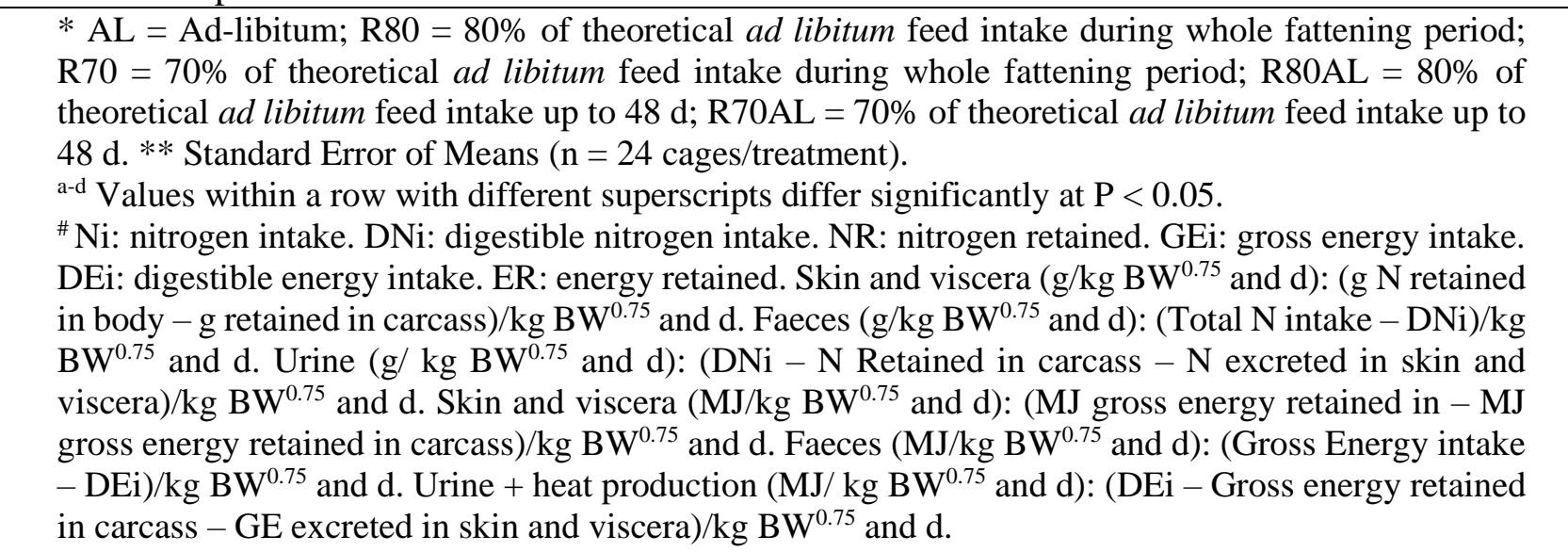 } \\
\hline
\end{tabular}




\section{GENERAL DISCUSSION}


General Discussion 


\section{GENERAL DISCUSSION}

\subsection{Effect of enzyme supplementation (Experiments 1 and 2)}

\subsubsection{Growth performance and slaughter traits (Experiments 1 and 2)}

Many studies have shown that enzymes supplementation have a positive effect on the feed efficiency (Gutiérrez et al., 2002a; Eiben et al., 2004; Cachaldora et al., 2004; Attia et al., 2012; Khalil 2018), specially on the first phases of the fattening period. This effect could be explained by a more efficient utilization of the nutrients (Gutiérrez et al., 2002a; GarcíaPalomares et al., 2006), particularly in young animals, because the native enzymatic capacity develops with age (Dojana et al., 1998). In this study, the quadratic effect found in the second phase have been previously observed by other authors. In this sense, Attia et al. (2012) reported a lower live weight at 8 weeks of age in the rabbits fed with the highest dose (750 ppm) of a multi enzymatic complex. El-Sagheer and Hassanein (2014) found higher positive effect on feed conversion ratio, body weight and BWG with $1 \mathrm{~g} / \mathrm{kg}$ of an enzyme complex and probiotic instead of $2 \mathrm{~g} / \mathrm{kg}$. Fraiha et al. (1997) also described an optimal enzyme dose supplementation according to the substrate. However, in this work during the whole fattening phase these beneficial effects were lost and this lack of effect might be explained by the low mortality observed during this trial $(1.77 \%)$ and the optimal management conditions. The limited effect of enzyme supplementation was also described by Cachaldora et al. (2004) in two experiments with $\alpha$-amylases. In one of them, mortality was high (27\% in control group and with a great incidence of diarrhoea) and amylases supplementation showed a very positive effect compared with the control group (mortality decreased up to $12.2 \%, \mathrm{P}=0.03$; FCR improved $+16 \%$, $\mathrm{P}=0.04)$, whereas in the other experiment, mortality was very low (2.6\% and almost any diarrhoea) and enzymes had no positive effects. In the same way, Gutiérrez et al. (2002a) 
found that the enzymatic supplementation reduced mortality in the whole fattening period compared with control group when it was moderate (6.9 vs. 13.9\%).

The results obtained in carcass traits match with Abaza and Omara (2011). They also found no effects on carcass weight and carcass yield, but observed that rabbits fed with enzymes had high relative viscera weight, as in our study, where treatments supplemented with enzymes showed higher weight of digestive tract, which could be related to the worst digestibility found in these treatments. Khalil (2018) also reported no significant differences in carcass parameters. El Sagheer and Hassanein (2014) found neither any effect on carcass yield, although they did not measure the total digestive tract, but the liver relative weight, was increased with enzyme supplementation. Neither Olorutola et al. (2018) found a significant effect with a multi-enzyme supplementation on carcass traits or in any internal organs. In contrast, El-Aziz et al. (2019) reported a significant differences in most of the carcass traits studied (carcass yield (\%), forequarter (\%) and hindquarter (\%)) in rabbits supplemented with a multi-enzymes preparation fortified with sodium butyrate and housed in a semi closed rabbitry of $180 \mathrm{~m}^{2}$ with natural ventilation. Likewise, a better carcass yield with enzyme supplementation were also found by Hernandez-Martínez et al. (2017) and Shanmuganathan et al. (2004). In the experiment 2 , in contrast to results found in experiment 1 , none of the performance traits studied showed a dose effect, probably because in experiment 2 the highest dose was only $200 \mathrm{ppm}$. The reason why a higher enzyme dose, based on the results of experiment 1 , was not used in this experiment was because experiment 1 and 2 were done at the same time. The lack of effects with the enzyme supplementation on productive parameters have been observed previously by other authors (Falcao-e-Cunha et al., 2007; Gutiérrez et al., 2002a; Cachaldora et al., 2004) and the low mortality (1.85\%) and optimal conditions could explain this lack of effects observed. 
The higher feed intake of diet B was due to the higher proportion of NDF $(+5,05 \%)$ and the lower DE (- 6,76\%) compared to diet A. Due to the homeostatic mechanism, rabbits can regulate the feed intake to consume a constant energy, within reasonable limits (Xiccato and Trocino, 2010). According to Maertens et al. (1997) and De Blas et al. (1999), fibrous diets decrease the digesta retention time and increase feed intake but impair the FCR.

In the first phase, the worst growth of the rabbits fed with diet $\mathrm{B}$ could be due to two effects. On one hand, because rabbits do not have completely developed the digestive physiology at $34 \mathrm{~d}$ of age (Gutiérrez et al., 2002b) and they could not compensate the decrease in energy with a higher feed intake (although a tendency was observed) impairing the growth. On the other hand, young animals have high requirement in protein and AA, not only for tissues growth, but also for the development of the digestive tract and the maintenance of gut mucosa function (Carabaño et al., 2009). In this sense, Maertens et al. (1997) and Trocino et al. (2000) reported a detrimental effect on growth during the first days of fattening when CP content in feed was lower than $15.6 \%$. In the second phase, rabbits were able to intake more feed and growth was similar in both groups.

The difference in DWG between both periods could show that the protein requirements in rabbits during the fattening period depends on the age. A protein level under $15 \%$ during the first days decrease growth performance (Maertens et al., 1997; Trocino et al., 2000 and 2013; Martínez-Vallespín et al., 2011). However, in contrast to the results observed by Maertens et al. (1997), Trocino et al. (2000 and 2013) and Martínez-Vallespín et al. (2011) reported that growth performance only tended to decrease during the whole phase.

In our Experiment, diet B had higher NDF and lower energy content, increasing the development of the digestive tract and increasing the feed intake, what could have favoured 
the compensatory growth, as reported by Martínez-Vallespín et al. (2011) in feeds with high fibre content. As a consequence of the higher feed intake (in the second and whole fattening phases) and the lower growth (in the first phase) FCR was impaired in diet B.

Although diet B had higher digestive tract, and full and empty stomach weights, the slaughter weight and carcass weight were higher in diet A. In general, feeds with higher fibre content used to have more stomach content in rabbits (De Blas et al., 1986; Parigi Bini et al., 1994), and also lower caecal content (Gidenne and Pérez 1994, Gidenne, 2000, Álvarez et al., 2007) although it depends on the variations of fibre content in the diets. Values over or under $39.5 \% \mathrm{NDF}(\% \mathrm{DM})$ in feed could increase caecal content (De Blas et al., 1999), because it is the level that minimized the caecal content weight. Due to the lower slaughter live weight and carcass weight in animals fed diet B, carcass yield was similar between both types of diets. Many authors have reported no effect on carcass yield using both different protein levels or diets with different fibre and energy content (Parigi Bini et al., 1994; Maertens et al., 1997). Some studies have shown an increased in carcass yield with increasing levels of NDF (Fabre et al., 2006); but always that these levels are close to the optimal one that minimized the caecal content. On the contrary, an excess of NDF can impair carcass yield (Margüenda et al., 2006 and 2012; Villena et al., 2008; Trocino et al., 2011). El-Kelawy and El-Shafey (2017) showed a decrease in carcass yield with higher doses of date stone meal (with high NDF and low energy and protein levels), but enzyme supplementation was able to compensate partly or completely, depending on date stone meal dose, the drop in carcass yield.

\subsubsection{Apparent total-tract digestibility (ATTD) (Experiments 1 and 2)}

The negative results on digestibility observed in experiment 1, were also found by Bolis et al. (1996), who found a detrimental effect on DE and ME when an enzymatic compound, 
also from fungus origin, was included in a basal feed with high fibre content $(52.5 \%$ NDF) in adult rabbits. A negative effect on DM and OM digestibility with enzyme supplementation was also reported by Castrovilli et al. (1995). Most of the studies (Falcao-e-Cunha et al. 2007) have not found significant improvements on digestibility when enzymes are used, although some of them have observed an improvement on digestibility (Makled et al., 2005; GarcíaRuiz et al., 2006; Abaza and Omara, 2011).

The impairment on digestibility detected, could be explained by some kind of interaction between the enzymatic activity and the digestive physiology of the rabbits, or between endogenous enzymes of the animal (Bolis et al., 1996), as well as among the exogenous enzymes themselves. According to Barekatain et al., (2013), in a work done in chickens, the addition of xylanases and proteases, together or separated, showed that could have been a negative interaction between them, because the same positive results were not found whether enzymes were added together or separately. This hypothesis, of possible interaction among proteases with other exogenous enzymes, has been also proposed by other authors (Naveed et al., 1998; Olukosi et al., 2007). Otherwise, Attia et al. (2012) observed no interaction with the endogenous proteases in rabbits when adding an enzymatic compound that contained $\beta$-glucanases, celulases, $\alpha$-amilases, proteases and lipases. In this study, a positive effect of the exogenous enzymes was reported on the final live weight and in the activity of amylase, lipase and protease in serum, pancreatic tissues, and intestinal content. However, and as it is evidenced by the literature, nowadays it is not deeply understand the mode of action of the exogenous proteases on the digestive physiology, and even less on the interaction between proteases and xylanases (Barekatain et al., 2013). 
In experiment 2, enzyme supplementation had no effect on digestibility of any of the nutrients studied, probably because of the lower doses used. Type of diet impaired digestibility, probably due to the higher content in NDF in diet B, as many studies have shown the negative correlation between fibre content and energy and fibre digestibility (de Blas et al., 1999).

\subsubsection{Carcass chemical composition and nitrogen and energy balances (Experiments 1 and 2)}

Regarding the carcass composition there was no effect of enzyme supplementation, because to affect carcass composition significantly, energy and/or protein intake should be quite higher or lower than the optimal dairy recommendation (Xiccato, 1999).

The lower content in EE and GE on the carcasses of animals fed diet B could be due to the lower DE intake (-6.2\%) and the lower GE retention $\left(-0.20 \mathrm{~kJ} / \mathrm{kg} \mathrm{PV} \mathrm{PV}^{0.75}\right.$ and $\left.\mathrm{d}\right)$. Also, the lower growth during the first phase could have delayed the deposit of perirenal, inguinal, and scapular fat (Lebas and Ouhayoun, 1987; Ouhayoun, 1989). Dalle Zotte et al. (1997) reported higher fat deposition in carcasses of rabbits fed with high ratios of DE/DP during postweaning. Moreover, some authors (Ouhayoun and Cheriet, 1983; Fraga et al., 1983) have observed an increase of fat content and a decreased of nitrogen content in animals that consumed diets with lower ratio DP/DE. On the other hand, García et al. (1993) reported a lower fat content in carcasses of rabbits fed with higher NDF content, substituting barley by sugar beet pulp and Xiccato et al. (1993) using different DP/DE ratios during the fattening phase did not observe any variation neither on carcass composition nor in meat. El-Kelawy and El-Shafey (2017) found lower protein and lipid percentage in carcass with 10 and 20\% of date stone meal replacement, in a diet with more NDF and less energy and protein levels compared to the control. 
In the experiment 1 , the lack of effect of enzymes on nitrogen and energy balances is according to the lack of significant effects of enzymes on the whole fattening period, where any effect on FCR, as well as nor on CP digestibility was observed. However, due to the lower digestibility of GE, there was significant differences in GE excretion in faeces, being higher in the treatments supplemented with enzymes.

The amount of $\mathrm{N}$ excreted is lower than the calculated by Maertens et al. (2005), for rabbits from 0.8 to $2.5 \mathrm{~kg}$ of $\mathrm{LW}$ (0.094 vs. $0.071 \mathrm{~kg}$ of N/rabbit, on average, in our experiment). In Spain, rabbits are slaughtered at lower LW (2-2.2 kg LW), this could explain this difference in $\mathrm{N}$ excretion, since the higher the live weight the higher the $\mathrm{N}$ excretion. This could be the cause why nitrogen balance obtained in this study are more similar to the results from Calvet et al. (2008), because growing conditions are more similar to ours than in the study of Maertens et al. (2005).

In diet $\mathrm{B}, \mathrm{GE}$ excretion in faeces increased due to the lower GE digestibility compared to $\operatorname{diet} \mathrm{A}$. As a consequence, DE intake, energy efficiency and retained energy, both in whole body and in carcass, were also lower in diet B. The interaction observed between diet and enzyme supplementation could be related with the higher efficiency of enzymes when feed digestibility decreases (Cowan et al., 1996).

Regarding $\mathrm{N}$ balance, animals of diet $\mathrm{B}$ consumed less DN (-16.4 g N/kg BW $\left.{ }^{0.75} . \mathrm{d}\right)$, and had a higher retention efficacy in carcass (0.514 vs. 0.538), but the $\mathrm{N}$ retained was lower $\left(-0.18 \mathrm{~g} \mathrm{~N} / \mathrm{kg}^{0,75}\right.$ and $\left.\mathrm{d}\right)$, probably due to the lower growth showed in the first phase. The $\mathrm{N}$ excreted in faeces was lower in diet B due to its lower protein content because protein digestibility was similar. Nitrogen in urine was also reduced, due to the lower DN consumption and to the higher nitrogen retention efficacy. Maertens et al. (1997) also observed an 
improvement in $\mathrm{N}$ efficacy in rabbits with lower protein content. However, Trocino et al. (2000) did not find any effect on $\mathrm{N}$ retention efficacy, although they found that a low protein level decreased N excretion, as well as Maertens et al. (1997). Maertens et al. (1998) also reported that a lower DP/DE ratio decreased the $\mathrm{N}$ excretion.

\subsection{Effect of lignin source and level (Experiment 3)}

\subsubsection{Growth performance and slaughter traits (Experiment 3)}

Chemical composition and physical structure of plant cell walls varies widely among the different sources of fibre. The botanical origin of the lignin can have important effects on digestibility (De Blas et al., 1999), caecal fermentation and enzymatic activity in caecum (Gidenne, 2000; García et al., 2002b), and performance (Pérez et al., 1994; Nicodemus et al., 1999). For example, according to Gidenne (2000) it seems that the botanical origin affects the FCR or could modulate the effect of the lignin level on FCR. However, Gidenne (2000) and Pérez et al. (1994) did not demonstrate an effect of lignin origin on OM digestibility, although demonstrated that botanic origin of the lignin could affect the average retention time of the digesta, probably it is related with the particle size (García et al., 1999).

According to Colin et al. (2007) Arbocel $^{\circledR}$ did not affect productive performance or final live weight when is compared with feeds or with lignin provided by "traditional" raw materials like alfalfa, whereas García et al. (2002a), reported an over intake of feed in animals fed with defatted grape seed meal and a FCR impairment. However, in this experiment, FCR was slightly increased with Arbocel $^{\circledR}$ compared to the grape meal, both in individual and collective fattening, without any significant effect on growth or feed intake. Griess et al. (1990) showed a higher caecum motility in rabbits fed diets supplemented with lignin derived from wood. In addition, García et al. (2002a) observed a lower caecal content weight with defatted 
grape seed meal. In our trial any differences were appreciated on total digestive tract nor caecum weights, probably because the effect of both lignin sources on passage rate was similar. Any effect was neither observed on carcass yield, although Colin et al. (2007) reported an increase of +1.1 points more with Arbocel®.

The influence on slaughter live weight observed among different levels of lignin contrasted with the no effect observed on the final live weigh in the zootechnical parameters. The explanation could be due to the selection of the 24 rabbits per treatment for the carcass traits. Animals were selected based on the average weight, having the animals with medium lignin level a lower average weight. In fact, when DWG, FCR and DFI were calculated, only for the animals selected for the carcass traits there were significant differences on DWG in the animals fed with the medium lignin level. But as both, the slaughter and carcass weight, were lower, the carcass yield was no affected by any treatment.

Low lignin level tended to increase the relative weight of the total digestive tract $(+0.45$ percentage units, on average). This tendency is most probably related with the higher caecum weight $(\mathrm{P}<0.05)$ also found in low lignin treatment. However, the greater weight of the digestive tract did not impair the carcass yield.

Digesta retention time in the digestive tract is an important feature of the diets because it is related with the voluntary intake and it can vary from 16 to 54 hours, depending on the fibre source. In standard diets average retention time is 18 hours on average (De Blas et al., 1999). Caecal retention is around a $60 \%$ of the total retention time, for this reason there is a negative correlation between caecal content weight and passage rate (De Blas et al., 1999) and dry matter intake (García et al., 2002b). 
Lignin level influences the average digesta retention time and, therefore, the passage rate, and modifies the caecum weigh as it was noted by several authors (Gidenne and Pérez 1994; Nicodemus et al., 1999; Gidenne, 2000; Nicodemus et al., 2007). Nicodemus et al. (1999) reported that lower lignin level, increased caecal content weight and decreased feed intake in isoenergetic diets. Recently, Caîsin et al. (2020) also observed lower full caecum and full gastrointestinal tract in rabbits fed with high lignin diets (over 7.5\% DM) when soluble fibre was low (8.2\%). Usually, if feeds energy concentration is between 9.2 and $13.4 \mathrm{MJ} \mathrm{DE} / \mathrm{kg}$ (Gidenne and Pérez, 1994), rabbits are able to adjust their feed intake in order to keep the daily intake of DE, maintaining the growth rate during the fattening period (Lebas, 1975; Partridge et al., 1989, Gidenne and Pérez, 1994) and reaching similar final weights (Nicodemus et al., 1999; Gidenne and Pérez, 1994; Colin et al., 2007). But if the lignin level is very high the feed consumption increases (Gidenne and Pérez, 1994 Gidenne, 2000; Caîsin et al., 2020), but an impairment in FCR is produced (Gidenne, 2000; Trocino et al. 2013; Caîsin et al., 2020). Below a minimum of 4.1\% ADL (\%DM), Pérez et al., (1994) and Nicodemus et al. (1999), have reported a lower growth rate and feed intake, for this reason is recommended to incorporate a minimum of $4.13 \% \mathrm{ADL}(\% \mathrm{DM})$ in diets of rabbits.

These results agree with our work, where the medium and high lignin levels also had lower relative caecum weight, compare with low level lignin, that could be linked with a faster passage rate, but without significant effect on feed intake. In the same way, final live weight nor DWG were significantly affected, because energy supply satisfies rabbits requirements, and therefore, DE intake was similar in all treatments, as noted by Gidenne (2000) and Pérez et al. (1994). 
Although total digestive tract weight was lower with the medium and high lignin levels, carcass yield was not significantly affected, as it was also observed by Caîsin et al. (2020). According to Nicodemus et al. (1999) fibre level has an opposite effect in the stomach than in the caecum. However, in this experiment this effect was not observed in the stomach but was noted in caecum, for this reason differences in carcass yield could have been found. Wu et al. (2018) reported increased stomach relative weight, stomach content relative weight, caecal relative weight, and caecal content weight with increasing NDF levels. In fact, Colin et al. (2007) reported a tendency to increase 0.8 points carcass yield with increasing lignin level. However, according to Xiccato (1999), neither the fibre nor any of its fractions play a specific role on carcass quality, in addition to its role to modify energy concentration. only if the fibre concentration modifies it in excess and impair rabbit's growth, carcass yield is not modified.

Some papers (Pérez et al., 1994; Gidenne et al., 2001; Wu et al., 2018) have reported a better mortality, sanitary risk index and morbidity in rabbits fed with higher lignin levels, however, due to the low mortality in this experiment, no significant differences were found. However, in order to avoid the use of antibiotics and prevent the epizootic rabbit enteropathy (ERE), the latest researches have recommended the inclusion of moderate levels of soluble fibre (11-12\%; Martínez-Vallespín et al., 2011; Trocino et al., 2013; Delgado et al., 2018), but as long as ADL and particle size requirements are met.

\subsubsection{Apparent total-tract digestibility (ATTD) (Experiment 3)}

Lignin source influenced on OM and DM digestibility in agreement with the results noted by Gidenne (2000). García et al. (2002a), reported a positive effect of defatted grape seed meal on the enzymatic activity of the small intestine, what could show a higher functional capacity of gut mucosa in rabbits fed with this fibre source. 
GE digestibility was decreased in medium and high levels. As it was reported by De Blas et al. (1999) an increase in ADF content in the diet decreases the digestible energy. Other authors (Gidenne and Pérez, 1994; Nicodemus et al., 1999; Gidenne, 2000; Trocino et al. 2013, Caîsin et al., 2020) have also observed worse digestibility rates (DM, OM, CP, GE and/or NDF) with increasing levels of lignin, due to a reduction of the retention time (Gidenne, 2000) and the own negative effect of the lignin on the feed digestion/fermentation (Gidenne and Pérez, 1994; Trocino et al., 2013). Like in other species, lignin could hinder the rabbit's digestion due to the covalent links with other components of the cell wall (Van Soest, 1994). Generally, it is observed a protein digestibility reduction when lignin content is increased (Falcao-e-Cunha, 1986, Gidenne, 1987 and Motta, 1990), although Nicodemus et al. (1999) and Gidenne (2000) reported an increased in CP with higher levels of lignin. On the other hand, García et al. (2002a) and Gidenne and Pérez (1994) did not find any difference on protein digestibility. However, in this experiment a decreased in protein digestibility was only observed with a medium level of lignin. Other authors, as it was observed in this experiment, did not find any difference on fibre digestibility, despite is usually observed an impairment on NDF digestibility with higher lignin levels (Gidenne and Pérez, 1994; Nicodemus et al., 1999; García et al., 2002). Regarding EE digestibility there is a lineal increased with the increase of lignin level. As previously it has been described, higher lignin level usually impairs nutrient digestibility, therefore, this EE digestibility increment could be due to the slightly higher fat content and more soya oil in diets of higher levels of lignin. According to Maertens, (1998) vegetable oils are highly digestible and Casado et al. (2010) also found that EE digestibility of vegetable oils was higher. Moreover, Fernández et al. (1994) and Fernández and Fraga (1996), reported that a higher EE in diets improved EE digestibility, although ADF content was higher, without any effect on the GE intake nor in the energy efficacy retention. Caîsin et al. (2020) 
also observed a higher EE digestibility in high lignin diets, because in order to keep diets isoenergetic, higher levels of fat in form of soya oil as well were used.

\subsubsection{Carcass chemical composition and nitrogen and energy balances.} (Experiment 3)

In this experiment GE retention efficacy, digestible energy intake or energy excreted by skin and viscera, urine and heat production were not affected by the lignin level, despite a higher fibre content could decrease energy retention (De Blas et al., 1999). On contrast, Caîsin et al. (2020) observed higher fat deposition in high lignin levels. However, in those diets, EE content was double than in low lignin level diets and could have played a role on fat deposition.

Due to the lower protein digestibility in medium and high lignin levels, nitrogen digestible intake was lower $(\mathrm{P}<0.05)$ in these diets, whereas the $\mathrm{N}$ utilization increased, therefore, $\mathrm{N}$ retained was similar for the three lignin levels studied. These results agree with Maertens et al. (1997) that reported an improvement of the $\mathrm{N}$ retention in the rabbits fed with a lower protein intake. However, $\mathrm{N}$ excretion in faeces, despite the worse $\mathrm{CP}$ digestibility, was not modify. Nitrogen excreted via urine decreased in medium and high lignin feeds, probably because retained nitrogen was similar but digestible nitrogen was lower. Nitrogen amount excreted via faeces was lower than in the previous experiments $\left(0.790\right.$ vs. $0.825 \mathrm{~g} / \mathrm{kg} \mathrm{PV}{ }^{0.75} . \mathrm{d}$, on average) because the $\mathrm{N}$ digestibility was higher (68.0 vs $71.2 \%)$. However, the $\mathrm{N}$ in urine was higher than in previous experiment $\left(0.930\right.$ vs. $\left.0.597 \mathrm{~g} / \mathrm{kg} \mathrm{PV}^{0.75} . \mathrm{d}\right)$ due to the higher DN intake (1.962 vs. $1.731 \mathrm{~g} / \mathrm{kg}$ ) and the lower $\mathrm{N}$ retained (1.032 vs. $1.090 \mathrm{~g} \mathrm{~N} / \mathrm{kg} \mathrm{LW}^{0,75}$.d). Even so, these results are lower than the ones calculated by Maertens et al. (2005), but more similar to the ones of Calvet et al. (2008). 
Because $\mathrm{N}$ and energy retention were not modified by the different treatments, carcass composition was neither modified. In this sense, DP/DE ratio and/or amount of fibre in feed must be extremely high or extremely low to have an influence on energy and protein content in the rabbits (Maertens, 1999 and Xiccato, 1999).

\subsection{Effect of feed restriction (Experiment 4)}

\subsubsection{Growth performance and slaughter traits (Experiment 4)}

One of the practical applications of this technique is the reduction of post-weaning mortality (Gidenne et al., 2009a, 2012, and 2017a; Romero et al., 2010; Alabiso et al., 2017). In this trial was not observed any difference among groups, that may have been because the mortality was moderate ( $12.8 \%$ on average). In fact, in other studies the feed restriction did not reduce the mortality rate below $9-17 \%$ when that of control group was between 15 and 23\% (Gidenne et al., 2009c; Knudsen et al., 2014; 2017), or even tended to increase it (Birolo et al., 2020), although other authors found very positive effects (Birolo et al., 2016; Romero et al., 2010), even compared to a medicated feed (Alabiso et al., 2017). There is no clear explanation for these differences among studies, and a combination of factors like the farm health status, diet, method of feed restriction employed, or type of housing might be behind them.

During the restriction period there is an impairment of growth (Romero et al., 2010; Gidenne et al., 2012 and 2017a). However, the effect on FCR is not so clear. Romero et al. (2010) also observed an impairment of FCR during the restriction period, but other authors have not found any effect (Gidenne et al., 2012; Birolo et al., 2016), or describe an improvement that could range between 5 and 10\% (Alabiso et al., 2017; Gidenne et al., 2017a; Knudsen et al., 2017). 
The compensatory growth observed in the treatments re-fed ad libitum in the second phase (R80AL and R70AL) has also been shown by many authors (Romero et al., 2010; Birolo et al., 2016; Gidenne et al., 2012, 2017a; Knudsen et al., 2017) and its intensity depends on the restriction level. The animals restricted also in the second phase had a similar growth rate than the control group, that might be explained because the effect of feed restriction on growth is more severe at the beginning of the restriction period (just after the weaning), than later (Gidenne et al., 2012). However, as the increase of feed intake was moderate compared to the compensatory growth in the second phase, the FCR improved with respect to the ad libitum animals, as it has been described by Gidenne et al. (2017a). Considering the whole fattening period, animals of R80AL group had a similar growth rate and lower feed conversion ratio than ad libitum, whereas R70 group had the lowest daily gain and was the only restriction group that reduced cold carcass weight compared with the ad libitum, although the FCR was similar than in the control. These results agree with those observed by Birolo et al. (2016) that did a restriction up to $58 \mathrm{~d}$ and Knudsen et al. (2017) until $63-64 \mathrm{~d}$. The reasons for a better feed efficiency have been described by a better digestibility of nutrients (Gidenne et al., 2012; Birolo et al., 2016; Knudsen et al., 2017). However, in this trial, digestibility (Table 4) was measured in the second phase, and there was only a significant improvement in the digestibility of $\mathrm{CP}$ in the animals that remained restricted, what could explain only partially the improvement in FCR during the second phase. Therefore, the compensatory growth and better FCR cannot be completely explained by the feed digestion and neither by a better nitrogen or energy retention efficiency (Table 6). Thus, the compensatory growth could also be of metabolic origin as it has been described in other species. In poultry, the compensatory growth observed in previously restricted animals has been rather associated to a decrease on maintenance costs or heat production. So, the increase of feed intake leads to an improvement 
in growth efficiency (Sahraei, 2012). In other studies, this better efficiency could be associated to an increase in the concentration, absorption and utilization of VFA, as it was observed in restricted animals (Gidenne and Feugier, 2009; MacDonald et al., 2011), although in this work they have not been measured. This hypothesis could be supported with the results of the nitrogen and energy excretion because it was observed lower excretion in both parameters (Table 6) in restricted animals. Unlike the observations by other authors (Romero et al., 2010; Gidenne et al., 2017a; Knudsen et al., 2017), the rabbits restricted only during the first phase (R70AL and R80AL), reached an acceptable body weight at slaughter for the Spanish market (2 kg BW). Birolo et al. (2016) reached also a similar final weight, but feed restriction was moderate (93\% of ad libitum intake).

The lack of differences on dressing out percentage after a restriction period is in agreement with other studies (Tumová et al., 2006; Birolo et al., 2016; Chodová et al., 2019). However, other authors (Gidenne et al., 2012; Knudsen et al., 2017; Birolo et al., 2020) reported an impairment of the carcass yield. Normally, the impairment is related to higher weight of the full tract associated with the development of internal organ such as small and large intestines, caecum and the liver during the restriction period and refeeding (Tumová et al., 2016). In this work, R70AL had the higher digestive tract and full stomach weight, but without any impairment in carcass yield. In the same way, animals of treatment R70AL had the greater liver weight, neither without effect in carcass yield. Gidenne et al. (2012) and Knudsen et al. (2017) also reported a heavier stomach and livers at slaughter when animals were restricted, based on the faster growth of the digestive organs after a restriction period, during the compensatory growth. The higher weight of liver after restriction period could be related to the major functional demands of liver, such as glycogen storage (Knudsen et al., 2017) or a larger diameter of the hepatocytes (Tumová et al., 2016) detected in restricted 
animals. Greater differences could be expected when restriction is more severe, $<70 \%$, or for long periods (from 4 to 12 weeks of age) (Birolo et al., 2016).

\subsubsection{Apparent total-tract digestibility (ATTD) (Experiment 4)}

The improvement on protein digestibility with the restriction has been previously observed in various works (Xiccato et al., 1992; Gidenne and Feugier, 2009; Birolo et al., 2016; Knudsen et al., 2017), and it is probably accounted for the larger mean retention time associated to restricted rabbits compared to the ad libitum group (Gidenne and Feugier, 2009). This effect was higher in the treatments that continued restricted all the whole fattening period. It seems that the animals refed ad libitum lost this effect and tended to have a similar digestibility than the control group, as it has been observed by Tumová et al. $(2003,2007)$ and Knudsen et al. (2014).

Regarding the digestibility of the other nutrients, according to Gidenne et al. (2012) is necessary a restriction period between 8 and $10 \mathrm{~d}$ to observe an improvement, however, we did not observe any positive effect on digestibility after $16 \mathrm{~d}$ of restriction. The lack of consistency among results of the different works on digestibility improvement may be caused by the variation on the intensity, duration, and the feed composition (Gidenne et al., 2012). There are results that observed an improvement in digestibility of different nutrients $(\mathrm{CP}, \mathrm{CE}$, fibre, etc.), both during (Di Meo et al., 2007; Tumová et al., 2007; Gidenne et al., 2009a y b) and after the restriction phase (Ledin, 1984; Birolo et al., 2016), but there are others that did not observe any effect (Díaz Arca et al., 1999; Gidenne and Feugier, 2009; Tumová et al. 2016). 


\subsubsection{Carcass chemical composition and nitrogen and energy balances} (Experiment 4)

The increase of carcass protein content in restricted animals is in agreement with Schlolaut et al. (1978) who described with two restriction levels (80 and 60\%) a sharp increase in carcass protein content (12 percentage units, on average). A higher protein content is usually accompanied by lower fat content (Schlolaut et al., 1978), but in this experiment it was observed only in the R70 group. However, Xiccato (1999) and Birolo et al. (2016) did not find considerable changes in the empty body protein. This could be partially explained by the expression of the data, done in DM in our trial and in fresh matter in these studies. The higher ash content in the carcass of restricted animals could be explained because, according to Pálsson (1955), the restriction should impair more the tissues that have been developed earlier (digestive tract) than those of later development (bones, muscle and fat).

The lower fat and energy content in the carcass of restricted animals are usually observed during or even after the restriction, independently of the strategy followed (Xiccato, 1999; Xiccato and Trocino, 2010; Gidenne et al., 2012; Knudsen et al., 2017). Gondret et al. (2000) showed that changes in the nutritional status regulate intramuscular lipid deposition without changing muscular fibre type composition. It might be related to the reduction of the activity of the enzymes involved in the biosynthesis of fatty acids (enzyme malic and glucose6-fosfate dehydrogenase), observed even after the feed restriction (Gondret et al., 1997). However, we observed that the treatments re-fed from $48 \mathrm{~d}$ onwards had a similar fat content than rabbits fed ad libitum. Despite most of the studies described a lower fat content in carcass, Birolo et al. (2016) observed a higher content after the re-feeding phase; probably, the lower feed restriction and the longer fattening period might have affected those results compared to those in this paper. 
In general, there is an improvement in the nitrogen balance with feed restriction (Gidenne et al., 2017b). However, the discrepancies observed among studies could depend on the different slaughter weights (Calvet et al., 2008) or dietary $\mathrm{N}$ content (Xiccato et al., 2005; Gidenne et al., 2013; Tazzoli et al., 2015) or the restriction program (Birolo et al., 2016 and 2017). Protein retention efficacy is usually improved when digestible protein intake or the ratio DP/DE decreases (Motta Ferreira et al., 1996; Maertens et al., 1997). The energy balance followed the same trend than the nitrogen one. Except R80AL, restricted groups had less energy retained in carcass, skin and viscera, and less energy losses via urine and heat production, what could explain partially their compensatory growth.

\subsection{Effect of slaughter weight on carcass yield}

The main objective of this Thesis was to improve the dressing out percentage with two nutritional strategies: 1) increasing carcass weight due to a greater deposition of protein and/or fat with the use of enzymes and 2) reducing the relative weight of the digestive tract by using an enzymatic supplementation, increasing lignin levels and applying different levels of feed restriction.

Contrary to the hypothesis, enzymes impaired digestibility and, consequently, increased the relative weight of the total tract by $2.7 \%$ (experiment 1 ). However, this negative effects on digestibility has been also found by other authors (Bolis et al., 1996). In experiment 2, total digestive tract and stomach weight increased by $5 \%$ in the diet with the lowest DE and DP. This effect has also been observed in diets with high fibre content (De Blas et al., 1986; Parigi Bini et al., 1994). In experiment 4, feed restriction did not reduce relative weight of the digestive tract, except in the animals restricted $70 \%$ of AL intake that had an opposite effect 
and increased its digestive tract weight by $6.2 \%$. On the contrary, total digestive tract decreased $1.43 \%$, on average, with the increase of ADL level in experiment 3.

Considering that digestive tract is between $20-21 \%$ of the live weigh of the animals (Margüenda et al., 2012), some effects on carcass yield could not have been expected. In part, this lack of effects in carcass yield might be explained by de differences observed in the slaughter weights among experiments. The average slaughter weight in experiments $1,2,3$ and 4 was 2349, 2319, 2450 and $2151 \mathrm{~g}$, respectively. In order to analyse the effect of slaughter weight on carcass yield it was performed a regression analysis. Four regression equations were obtained, but the slope was common for all of them (Figure 4). These results indicated that for each increase of $100 \mathrm{~g}$ in slaughter weight, the carcass yield increases by 0.24 percentage units. Comparing the four experiments, the dressing out percentage was significantly lower $(\mathrm{P}<0.001)$ only in experiment 4 , due to the lower final weight of the animals. This lower live weight could be explained, by two causes: the lower final weight of rabbits as a consequence of the restriction and because the fattening trial was carried out in collective cages, with 5 rabbits per cage, where animals usually finish growing period with lower weight than in individual cages. 
Figure 4. Effect of slaughter weight on carcass yield.

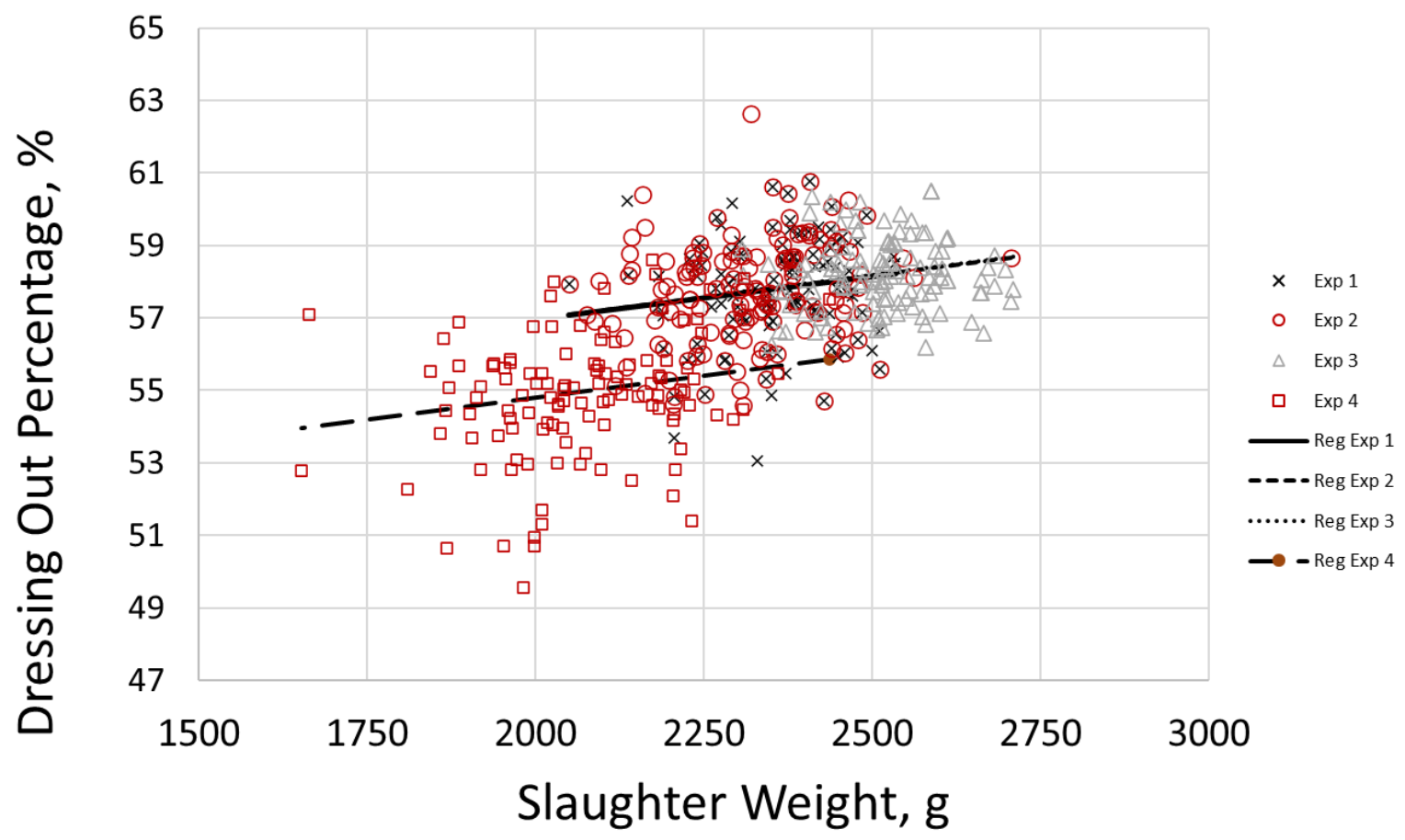




\section{GENERAL CONCLUSIONS AND}

\section{IMPLICATIONS}


General conclusions and implications 


\section{GENERAL CONCLUSIONS AND IMPLICATIONS}

\subsection{Conclusions}

1. The nutritional strategies studied in this Thesis had no effect on carcass yield. However, feed restriction increases crude protein content and decreases ether extract in carcass composition, without impairing performance, what could have a positive influence nowadays that people is looking for healthier, low fat food.

2. Enzyme supplementation in rabbits with good sanitary conditions:

- $\quad$ Seems not to have a clear positive effect in the productive performance during the whole fattening period.

- In case of using an enzyme complex in diets that supply all the nutritional requirements would be recommended only for the first phase (34 to $48 \mathrm{~d}$ ).

- In the second phase $(48-60 \mathrm{~d})$ would not be recommended to supplement more than 400 ppm of the enzyme complex.

- In diets with lower nutritional value enzyme complex improved nitrogen and energy balance, reducing the energy losses and nitrogen excretion to the environment.

3. Feeds with lower DP/DE ratio and more NDF impair nutrient digestibility and FCR but reduce fat carcass content and the $\mathrm{N}$ excretion to the environment up to $12 \%$.

- $\quad$ A feeding program by phases would be more recommendable, more adapt to rabbits needs in each moment, to reduce $\mathrm{N}$ excretion via faeces and urine.

4. Lignin source and level have no important effect on growth performance and carcass traits, despite a slightly negative effect of lignin level on digestibility and Arbocel@ on feed conversion rate. 
5. Feed restriction up to $80 \%$ of ad libitum intake in the first fattening phase, followed by ad libitum intake in the second phase had a similar growth rate, lower feed conversion ratio, and tended to have higher digestible nitrogen and energy retention efficiency than the group fed ad libitum.

- However, restriction of ad libitum intake up to $70 \%$ during the whole fattening period reduced the cold carcass weight, although it increased the protein content of the carcass and reduced the fat one.

6. Feed restriction during post-weaning period of fattening (34-48 d) reduce the farm environmental impact, without impair growth performance and dressing out percentage.

7. In non-enteropathy conditions, none of the strategies studied had effect on mortality. 


\subsection{Implications}

Carcass yield is an important quality and profitable trait for the meat industry. Nutrition plays an important role on it, but the strategies studied in this Thesis have not shown an effect and should not be recommended for that purpose. However, if the objective was to obtain lower fat carcasses, maybe due to the customer demand for lean meat, restrict feed intake $80 \%$ of AL intake in the first fattening phase (35-49 d) and AL in the second phase (49-61 d) would be interesting. In addition, performance is globally improved.

From the environmental point of view, feed restriction and formulation with lower CP, GE and higher NDF strategies decreased the $\mathrm{N}$ excretion, and therefore, the environmental impact.

Based on the present work, future lines of research could be:

- Study the nutrient requirements of fattening rabbits in the different growing phases.

- Differences among enzyme supplements and types. Interaction among exogenous and/or endogenous enzymes of the rabbit.

- Study other nutritional strategies that could improve carcass yield and/or meat quality. 
General conclusions and implications 


\section{REFERENCES}


References 


\section{VIII.REFERENCES}

A.O.A.C. (2005). Official Methods of Analysis. Association of Official Analytical Chemist. USA.

Abaza, I.M., and Omara, M.E. (2011). Effect of dietary corn cobs and enzymes supplementation on growing rabbits performance. J. Product. \& Dev., 16(3), pp. 507527.

Abd El-Aziz, A.H., El-Kasrawy, N.I., Abo Ghanima, M.M., Alsenosy, A.E., Abbas Raza, S.H., Khan, S., Memon, S., Khan, R. and Ullah, I. (2020). Influence of multi-enzyme preparation supplemented with sodium butyrate on growth performance blood profiles and economic benefit of growing rabbits. J. Anim. Physiol. Anim. Nutri., 104(1), pp.186195.

Abdel-Naby, A.M. (1979). Studies on some productive and reproductive traits in rabbit under Upper Egypt condition. M. Sc. Thesis. Assiut University, Assiut, Egypt.

Abdel-Wareth, A.A.A., Taha, E.M.M., Südekum, K.H. and Lohakare, J. (2018). Thyme oil inclusion levels in a rabbit ration: Evaluation of productive performance, carcass criteria and meat quality under hot environmental conditions. Anim. Nutr., 4(4), pp. 410-416.

AFNOR. (1997). Animal feeding stuffs. Determination of sequential cell-wall. Method by treatment with neutral and acid detergent and sulphuric acid. AFNOR, Paris, NF V18$12,11 \mathrm{ppg}$.

Alabiso, M., Di Grigoli, A., Mazza, F., Maniaci, G., Vitale, F. and Bonanno, A. (2017). A 3week feed restriction after weaning as an alternative to a medicated diet: effects on 
growth, health, carcass and meat traits of rabbits of two genotypes. Animal, 11(9), pp. 1608-1616.

Álvarez, J.L., Margüenda, I., García-Rebollar, P., Carabaño, R., De Blas, C., Corujo, A. and García-Ruiz, A.I. (2007). Effects of type and level of fibre on digestive physiology and performance in reproducing and growing rabbits. World Rabbit Sci., 15(1), pp. 9-17.

Attia, K.A., Sohair, Y. Saleh, S.A., El-hamidSafaa, A., ZakiAmal, A. and El-Sawy, M. (2012). Effects of Exogenous Multi-enzyme Feed Additive (Kemzyme) on the Activities of Certain Digestive Enzymes and Intestinal Morphology in Growing Rabbits. J. Agri. Sci., 4(3), pp. 35-44.

Aubret, J. and Duperray, J. (1992). Effect of cage density on the performance and health of the growing rabbit. J. Appl. Rabbit Res., 15, pp. 656-660.

Ayyat, M.S., Al-Sagheer, A.A., Abd El-Latif, K.M. and Khalil, B.A. (2018). Organic Selenium, Probiotics, and Prebiotics Effects on Growth, Blood Biochemistry, and Carcass Traits of Growing Rabbits During Summer and Winter Seasons. Biol. Trace. Elem. Res., 186(1), pp. 162-173.

Barekatain, M.R., Antipatis, C., Choct, M. and Iji, P.A. (2013). Interaction between protease and xylanase in broiler chicken diets containing sorghum distillers' dried grains with solubles. Ani. Feed Sci. and Tec., 182, pp. 71-81.

Berchiche, M., Lebas, F. and Ouhayoun, J. (1995). Utilization of field beans by growing rabbits. 1- Effects of supplementation aimed at improving the sulfur amino acid supply. World Rabbit Sci., 3(1), pp. 35-40. 
Berg, R.T. and Butterfield, R.M. (1979). Nuevos conceptos sobre desarrollo de Ganado vacuno. Acribia. Zaragoza.

Berg, E.P. and Marchello, M.J. (1994). Bioelectrical Impedance Analysis for the prediction of fat-free mass in lambs and lamb carcasses. J. Anim. Sci.., 72(2), pp. 322-329.

Bernardini, B.M., Castellini, C. and Lattaioli, P. (1995). Effect of sire strain feeding, age and sex on rabbit carcass. World Rabbit Sci. 3(1), pp. 9-14.

Bianospino, E., Wechsler, F.S., Fernandes, S., Roça, R.O. and Moura, A.S.A.M.T. (2006). Growth, carcass and meat quality traits of straightbred and crossbred botucatu rabbits. World Rabbit Sci., 14(4), pp. 237-246.

Bielański, P. (2000). The effect of environmental conditions on the growth rate and slaughter performance of rabbits of selected breeds. Rocz. Nauk. Zoot., 27, pp. 375-393.

Biovet (2008). Uso de enzimas en la alimentación animal. Available at: http://www.biovetalquermes.com/uploads/434935226ff0299.pdf

Birolo, M., Trocino, A., Zuffellato, A. and Xiccato, G. (2016). Effect of feed restriction programs and slaughter age on digestive efficiency, growth performance and body composition of growing rabbits. Anim. Feed Sci. Technol., 222, pp. 194-203.

Birolo, M., Trocino, A., Tazzoli, M. and Xiccato, G. (2017). Effect of feed restriction and feeding plans on performance, slaughter traits and body composition of growing rabbits. World Rabbit Sci., 25, pp. 113-122.

Birolo, M., Trocino, A., Zuffellato, A. and Xiccato, G. (2020). Effects of time-based feed restriction on morbidity, mortality, performance and meat quality of growing rabbits housed in collective systems. Animal, 14, pp. 626-635. 
Bolis, S., Castrovilli, C., Rigoni, M., Tedesco, D. and Luzi, F. (1996). Effect of enzymes addition in diet on protein and energy utilization in rabbit. In Proc.: 6th World Rabbit Congress, Toulouse, France, pp. 111-115.

Blasco, A., Estany, J. and Baselga, M. (1982). Evaluación de la calidad de la canal en conejo. VII Symposium de cunicultura., pp. 55-64.

Blasco, A., Baselga, M. and García, F. (1983). Análisis fenotípico de caracteres productivos en el conejo de carne. I. Caracteres de crecimiento. Arch. Zootec., 123(32), pp. 111-130.

Blasco, A., Ouhayoun, J. and Masonero, G. (1993). Harmonization of criteria and terminology in rabbit meat research. World Rabbit Sci., 1(1), pp. 3-10.

Blasco, A. and Ouhayoun, J. (1996). Harmonization of criteria and terminology in rabbit meat research. Revised Proposal. World Rabbit Sci., 4(2), pp. 93-99.

Cachaldora, P., Nicodemus, N., García, J., Carabaño, R. and De Blas, J.C. (2004). Efficacy of Amylofeed ${ }^{\circledR}$ in growing rabbits. World Rabbit Sci., 12(1), pp. 23-31.

Câisin, L., Martínez-Paredes, E., Ródenas, L., Moya, V.J., Pascual, J.J., Cervera, C., Blas, E. and Pascual, M. (2020). Effect of increasing lignin in isoenergetic diets at two soluble fibre levels on digestion, performance and carcass quality of growing rabbits: Anim. Feed. Sci. Technol., 262, 114396.

Calvet, S., Estellés, F., Hermida, B., Blumetto, O. and Torres, A.G. (2008). Experimental balance to estimate efficiency in the use of nitrogen in rabbit breeding. World Rabbit Sci., 16(4), pp. 205-211.

Camps, J. (1993). Peso óptimo de las canales de conejo. Cunicultura, 7-15. 
Cantier, J., Vezinet, A., Rouvier, R. and Dauzier, L. (1969). Allométrie de croissance chez le lapin (Oryctolagus cuniculus). In Proc: Principaux organes et tissus. Ann. Biol. Bioch. Biphys., 9(1), pp. 5-39.

Carabaño, R., Villamide, M.J., García, J., Nicodemus, N., Llorente, A., Chamorro, S., Menoyo, D., García-Rebollar, P., García-Ruiz, A.I. and De Blas, J.C. (2009). New concepts and objectives for protein-amino acid nutrition in rabbits: a review. World Rabbit Sci., 17(1), pp. 1-14.

Casado, C., Moya, V.J., Fernández, C., Pascual, J.J., Blas, E. and Cervera, C. (2010). Diet digestibility in growing rabbits: effect of origin and oxidation level of dietary fat and vitamin E supplementation. World Rabbit Sci., 18(2), pp. 57-63.

Castellini, C. and Bataglini, M. (1992). Prestazione productive e quailtà delle carni di coniglio: influenza della concetrazione nergetica della dieta e del seso. Zoot. Nutr. Anim., 18, pp. 251-258.

Castrovilli, C., Tedesco, D., Bolis, S. and Rigoni, M. (1995). Effetto di addizioni enzimatiche sulla digerabilità della sostanza organica e dell’energia nel coniglio. Atti XI Congr. Naz. ASPA. Grado. 119-120

Cervera, C. and Fernández Carmona, J. (2010). Climatic Environment. In: Nutrition of the Rabbit, 2nd Edition. C. de Blas and J. Wiseman (eds). CCAB International., pp. 267284.

Champ, M., Langkilde, A.M., Brouns, F., Kettlitz, B. and Collet, Y.L.B. (2003). Advances in dietary fibre characterisation. 1. Definition of dietary fibre, physiological relevance, 
health benefits and analytical aspects. Nutrition Research Reviews. Cambridge University Press,16(1), pp.71-82.

Chiericato, G.M., Rizzi, C. and Rostellato, V. (1993). Effect of genotype and environmental temperature on the performance of the young meat rabbit. World Rabbit Sci., 1(3), pp. 119-125.

Chiericato, G.M., Rizzi, C. and Rostellato, V. (1996). Meat quality of rabbits of different genotypes reared in different environmental conditions. In Proc. Proceeding of the 6th World Rabbit Congress, Toulouse, France, 3, pp. 141-145.

Chodová, D. and Tumová, E. (2013). The effect of feed restriction on meat quality of broiler rabbits: a review. Sci. Agric. Bohem. 44(1), pp. 55-62.

Chodova, D., Tumova, E. and Volek, Z. (2019). The effect of limited feed intake on carcase yield and meat quality in early weaned rabbits. Ital. J. Anim. Sci. 18(1), pp. 381-388.

Ciruzzi, B., Minoia, P., Bufano, G. and Muscio, A. (1973). Chemical characteristics of the meat and fat of rabbits of various breeds. Ann. Fac. Agr. Univ. di Bari, 26(2), pp. 797815.

Close, W.H. and Stanier, M.W. (1984). Effects of plane of nutrition and environmental temperature on the growth and development of the early-weaned piglet. 2. Energy metabolism. Anim. Prod., 38(2), pp. 221-232.

Cobos García, Á. (1993). Influencia de la dieta en la composición lipídica de la carne de conejo. PhD thesis, Facultad de Veterinaria. Universidad Complutense de Madrid. Madrid, Spain. 
Colin, M., Binet., E. and Prigent, A. Y. (2007). Influence de l'incorporation d'un concentré fibreux riche en lignine sur la mortalité, la croissance et le rendement à l'abattage du lapin. 12èmes J. Rech. Cunicole, Le Mans, France. pp. 113-116.

Consigli, R. (2001). ¿Qué es la calidad de la carne? 6 Jornada El Negocio de la Carne. La Voz del Campo EEA INTA Manfredi, Argentina.

Costantini, F. and Bosi, G. (1968). Aspetti produttivi e caratteristiche qualitative della carne di coniglio in rapport alla razza e alla conservazione. Ann. Fact Agr. Univ. Stu. Perugia, 23, pp. 161-181.

Cowan, W.D., Jorsbak, A., Hastrup, T. and Rasmussen, B.P. (1996). Influence of added microbial enzymes on energy and protein availability of selected feed ingredients. Anim. Feed. Sci. Technol., 60(3-4), pp. 311-319.

D’Agata, M., Preziuso, G., Russo, C., Dalle Zotte, A., Mourvaki, E. and Paci, G. (2009). Effect of an outdoor rearing system on the welfare, growth performance, carcass and meat quality of a slow-growing rabbit population. Meat Sci., 83(4), pp. 691-696.

Dal Bosco, A., Castellini, C. and Mugnai, C. (2002). Rearing rabbits on wire net floor or straw litter: behaviour, growth and meat quality traits. Livest. Prod. Sci., 75(2), pp. 149-156.

Dalle Zotte, A. (2002). Perception of rabbit meat quality and major factors influencing rabbit carcass and meat quality. Livest. Prod. Sci., 75(1), pp. 11-32.

Dalle Zotte, A. and Ouhayoun, J. (1998). Effect of genetic origin, diet and weaning weight on carcass composition, muscle physicochemical and histochemical traits in the rabbit. Meat Sci., 50(4), pp. 471-478. 
Dalle Zotte, A., Parigi Bini, R., Xiccato, G. and Cossu, M.E. (1997). Effetto della dieta e della durata del post-svezzamento sulla qualità della carcass e della carne di coniglio. Proc. XII Congresso ASPA, 23-26 June, Pisa, Italy, pp. 383-384.

Dalle Zotte, A., Celia, C. and Szendro, Zs. (2016). Herbs and spices inclusion as feedstuff or additive in growing rabbit diets and as additive in rabbit meat: A review. Livest. Sci., 189, pp. 82-90.

Daszkiewicz, T., Gugolek, A., Janiszewski, P., Kubiak, D. and Czoik, M. (2012). The effect of intensive and extensive production systems on carcass quality in New Zealand White rabbits. World Rabbit Sci., 20(1), pp. 25-33.

Daza, A., Mateos, A., Ovejero, I. and López Bote, C.J. (2006). Prediction of body composition in Iberian pig by means of Bioelectrical Impedance. Meat Sci., 72(1), pp. 43-46.

De Blas, J.C., Pérez, E., Fraga, M.J., Rodríguez, J.M. and Gálvez, J.F. (1981). Effect of diet on feed intake and growth of rabbits from weaning to slaughter at different ages and weights. J. Anim. Sci., 52(6), pp. 1225-1232.

De Blas, J.C., Santomá, G., Carabaño, R. and Fraga, M.J. (1986). Fiber and starch levels in fattening rabbit diets. J. Anim. Sci. 63(6), pp. 1897-1904.

De Blas, C, García, J. and Carabaño, R. (1999). Role of fibre in rabbit diets. A review. Ann. Zootech., 48(1), pp. 3-13.

De Blas, C. and Mateos, G.G. (2010). Feed Formulation. In: Nutrition of the Rabbit, 2nd Edition. C. de Blas and J. Wiseman (eds). CAB International, pp. 222-232.

Dehalle, C. (1981). Equilibre entre les apports azotés et énergétiques dans l'alimentation du lapin en croissance. Ann. Zootech., 30(2), pp. 197-208. 
Delgado, R., Nicodemus, N., Abad-Guamán, R., Sastre, J., Menoyo, D., Carabaño, R. and García, J. (2018). Effect of dietary soluble fibre and n-6/n-3 fatty acid ratio on growth performance and nitrogen and energy retention efficiency in growing rabbits. Anim. Feed Sci. Technol., 239, pp. 44-54.

Deltoro, J. and López, A.M. (1985). Allometric changes during growth in rabbits. J. agric. Sci., 105(2), pp. 339-346.

Deltoro, J. and López, A. M. (1986). Development of commercial characteristics of rabbit carcasses during growth. Livest. Prod. Sci., 15(3), pp. 271-283.

Deltoro, J, López, A.M. and Camacho, J. (1988a). Seasonal effects on the patterns of deposition of water, fat and protein in rabbit meat. Meat Sci., 23(2), pp. 87-97.

Deltoro, J, López, A.M. and Camacho, J. (1988b). Ecuaciones de predicción de la composición química de la carne de conejo. IV Congreso Mundial de Cunicultura. Budapest, pp. 352.

DeVries, J.W. (2010). Validating official methodology commensurate with dietary fibre research and definitions. In: Van der Kamp J.W., Jones J., McCleary B., Topping D. (ed). Dietary Fibre. New Frontiers for Food and Health, Wageningen Academic Publishers, The Netherlands, pp. 29-48.

Díaz Arca, F., Pérez Alba, L.M. and Pérez Hernández, M. (1999). Digestibility and energy retention by young rabbits fed different levels of intake. Ann. Zootech., 48(4), pp. 289295.

Di Meo, C., Bovera, F., Marono, S., Vella, N. and Nizza, A. (2007). Effect of feed restriction on performance and feed digestibility in rabbits. Ital. J. Anim. Sci., 6(1), pp. 765-767. 
Directive 2010/63/EU of the European Parliament and of the Council of 22 September 2010 on the protection of animals used for scientific purposes, 2010. Off. J. Eur. Union L276/33-L276/79.

Dojana, N., Costache, M., and Dinischiotu, M. (1998). The activity of some digestive enzymes in domestic rabbits before and after weaning. Anim Sci., 66(2), pp. 501-507.

Eiben, C.S., Mézes, M., Zijártó, N., Kustos, K., Gódor-Surmann, K. and Erdélyi, M. (2004). Dose dependent effect of cellulase supplementation on performance of early-weaned rabbit. In Proc. 8th World Rabbit Congress, Puebla, México. pp. 799-804.

Ebeid, T., Zeweil, H., Basyony, M. and Badry, H. (2012). The impact of incorporation of organic selenium into meat on growth performance, antioxidative status, and immune response in growing rabbits. In Proc. 10th World Rabbit Congress. Sharm El-Sheikh. Egypt. pp. 861-864.

El-Aziz, A.H.A., El-Kasrawy, N.I., Ghanima, M.M.A., Alsenosy, A.E.A.E., Raza, S.H.A., Khan, S., Memon, S., Khan, R. and Ullah, I. (2019). Influence of multi-enzyme preparation supplemented with sodium butyrate on growth performance blood profiles and economic benefit of growing rabbits. J. Anim. Physiol. Anim. Nutr., 104(1), pp.186195.

El-Kelawy, M. and El-Shafey, A. (2017). Effect of adding of enzyme complex (kemzyme) to diet containing date stone meal on blood parameters, immune response, microbial activity and carcass characteristics of growing rabbits. Egyptian Journal of Rabbit Science, 27(2), 485-506. 
El-Sagheer, M. and Hassanein, H.H.M. (2014). Effect of enzymes and probiotic mixture supplementation to the diet on performance and carcass criteria of growing females of three rabbit strains. Egyptian Poultry Science, 34(1), pp. 273-288.

Fabre, C., Juvero, M.A., Blas, E., Fernández Carmona, J. and Pascual, J.J. (2006). Utilización de un pienso rico en fibra digestible e indigestible y pobre en almidón en conejos de engorde: ensayo en condiciones de campo. In Proc. XXXI Symposyum de ASESCU. Lorca, España. pp 67-72.

Falcao-e-Cunha, L. (1986). Influence chez le lapin adulte de l'origine et du taux de lignine alimentaire sur la digestibilité de la ration et l’importance de la caecotrophie. 4e Journ. Rech. Cunicole. Paris. France. 10-11 déc., Communication nº8, 8.1-8.9. ITAVI ed, Paris.

Falcao-e-Cunha, L., Castro-Solla, L., Maertens, L., Marounek, M., Pinheiro, V., Freire, J. and Mourao, J.L. (2007). Alternatives to antibiotic growth promoters in rabbit feeding: A review. World Rabbit Sci., 15(3), pp.127-140.

FAO (Food and Agriculture Organization of the United Nations). (2013). FAOSTAT-Meat indigenous, rabbit. Carcass weight. [online]. Available in: http://www.fao.org/faostat/es/\#compare [Accessed: 29 May 2020].

Fathi, M., Abdelsalam, M., Al-Homidan, I., Ebeid, T., El-Zarei, M. and Abou-Emera, O. (2017). Effect of probiotic supplementation and genotype on growth performance, carcass traits, hematological parameters and immunity of growing rabbits under hot environmental conditions. J. Anim. Sci., 88(10), pp. 1644-1650.

Fedna. (2019). Tablas Fedna de composición y valor nutritivo de alimentos paras la fabricación de piensos compuestos. $4^{\text {a }}$ Edición. Fundación Española para el Desarrollo de la 
Nutrición

Animal.

Available

at:

http://www.fundacionfedna.org/ingredientes_para_piensos/granilla-de-uva.

Fekete, S. and Brown, D.L. (1993). The major chemical components of the rabbit whole body measured by direct chemical analysis, deuterium oxide dilution and total body electrical conductivity. J. Vet. Nutr., 2, pp. 23-29.

Fernández Martínez, C. (1993). Efecto de la incorporación de grasa en piensos fibrosos sobre la utilización digestiva de la dieta, crecimiento y calidad de la canal de conejos en cebo. PhD thesis. Universidad de Castilla-La Mancha. Spain.

Fernández, C. and Fraga, M.J. (1996). The effect of dietary fat inclusion on growth, carcass characteristics, and chemical composition of rabbits. J. Anim. Sci., 74(9), pp. 2088-2094.

Fernández, C., Cobos, A. and Fraga, M.J. (1994). The effect of fat inclusion on diet digestibility in growing rabbits. J. Anim. Sci., 72(6), pp. 1508-1515.

Fortun-Lamothe, L., Lebas, F., Lamboley-Gaüzére, B. and Bannelier, C. (2002). Prediction of body composition in rabbit females using total body electrical conductivity (TOBEC). Livest. Prod. Sci., 78(2), pp. 133-142.

Fourie, P.D. (1965). Grow and development of sheep with special reference to New Zealand breeds. PhD Thesis. University of Pretoria.

Fraga, M.J., De Blas, J.C., Pérez, F., Rodríguez, J.M., Pérez, C.J. and Galvez, J.F. (1983). Effect of diet on chemical composition of rabbits slaughtered at fixed body weights. $J$. Anim. Sci., 56(5), pp. 1097-1105.

Fraga, M.J., Torres, A., Pérez, E., Gálvez, J.F. and De Blas, J.C. (1978). Body composition in suckling rabbits. J. Anim. Sci., 47(1), pp. 166-175. 
Fraga, M.J., Pérez de Ayala, P., Carabaño, R. and De Blas, J.C. (1991). Effect of type of fiber on the rate of passage and on the contribution of soft faeces to nutrient intake on the rate of fattening rabbits. J. Anim. Sci., 69(4), pp. 1566-1574.

Fraiha, M., Furlan, A.C., Murakami, A.E. Martins, E.N., Scapinello, C. and Moreira, I. (1997). Utilização de complexo multienzimático em rações de frangos de corte contendo triticale. Ensaio de desempenho. Rev. Soc. Bras. Zootec., 26(4), pp. 765-772.

García, G., Gálvez, J. F. and de Blas, J. C. (1992). Substitution of barley grain by sugar-beet pulp in diets for finishing rabbits. 2. Effect on growth performance. J. Appl. Rabbit Res., 15 , pp. $1017-1024$

García, G., Gálvez, J.F. and De Blas, J.C., (1993). Effect of substitution of sugar beet pulp for barley in diets for finishing rabbits on growth performance and on energy and nitrogen efficiency. J. Anim. Sci., 71(7), pp. 1823-1830.

García, J., Carabaño, R. and De Blas, J.C. (1999). Effect of fiber source on cell wall digestibility and rate of passage in rabbits. J. Anim. Sci., 77(4), pp. 898-905.

García, J., Carabaño, R., Pérez-Alba, L. and de Blas, J.C. (2000). Effect of fiber source on cecal fermentation and nitrogen recycled through cecotrophy in rabbits. J. Anim. Sci., 78(3), pp. 638-646.

García, J., Nicodemus, N., Carabaño, R. and de Blas, J. C. (2002a). Effect of inclusion of defatted grape seed meal in the diet on digestion and performance of growing rabbits. $J$. Anim. Sci., 80(1), pp. 162-170. 
García, J., Gidenne, T., Falcao-E-Cunha, L. and De Blas, J.C. (2002b). Identification of the main factors that influence caecal fermentation traits in growing rabbits. Anim. Res., 51(2), pp. 165-173.

García-Palomares, J., Carabaño, R., García-Rebollar, P., de Blas, C. and García Ruíz, A.I., (2006). Effects of dietary protein reduction during weaning on the performance of does and suckling rabbits. World Rabbit Sci., 14(1), pp. 23-26.

García-Ruiz, A.I., García Palomares, J., García-Rebollar, P., Chamorro, S., Carabaño, R. and De Blas, J.C. (2006). Effect of protein source and enzyme supplementation on ileal protein digestibility and fattening performance in rabbits. Spanish Journal of Agricultural Research, 4, pp. 297-303.

Garitano, I., Liébana, C., Feliz de Vargas, E., Daza, A. and López Bote, C.J. (2012). Efecto de la sustitución del pienso convencional por cebada granulada, durante el periodo de acabado, sobre los resultados productivos, calidad de la canal, de la carne y de la grasa intramuscular de cerdos destinados a la producción de jamón de Teruel. Información Técnica Económica Agraria, 108(3), pp. 241-255.

Gidenne, T. (1993). Measurement of the rate of passage in restricted-fed rabbits: effects of dietary cell wall level on the transit of fibre particles of different sizes. Anim. Feed Sci. Technol., 42(1-2), pp. 151-163.

Gidenne, T. (1994). Effets d'une réduction de la tener en fibres alimentaires sur le transit digestif du lapin. Comparaison et validation de modèles d'ajustement des cinétiques d'excrétion fécale des marqueurs. Reprod. Nutr. Dev., 34(4), pp. 295-307. 
Gidenne, T. (2000). Recent advances and perspectives in rabbit nutrition: Emphasis on fibre requirements. World Rabbit Sci., 8, pp. 23-32.

Gidenne, T. (2003). Fibres in rabbit feeding for digestive troubles prevention: respective role of low-digested and digestible fibre. Livest. Prod. Sci., 81 (2-3), pp. 105-117.

Gidenne, T. (2015). Dietary fibres in the nutrition of the growing rabbit and recommendations to preserve digestive health: a review. Animal, 9(2), pp. 227-242.

Gidenne, T. and Feugier, A. (2009). Feed restriction strategy in the growing rabbit. 1 -impact on digestion, rate of passage and microbial activity. Animal, 3(4), pp. 501-508.

Gidenne, T. and García, J. (2006). Nutritional strategies improving the digestive health of the weaned rabbit. In: Maertens, L., Coudert, P. (Eds.), Recent Advances in Rabbit Sciences. ILVO, Melle (Belgium), pp. 229-238.

Gidenne, T. and Pérez, J.M. (1994). Apports de lignines et alimentation du lapin en croissance. I. Conséquences sur la digestion et le transit. Ann. Zootech., 43(4), pp. 313-322.

Gidenne, T., Arveux, P. and Madec, O. (2001). The effect of the quality of dietary lignocellulose on digestion, performance and health of the growing rabbit. Anim. Sci., 73(1), pp. 97-104.

Gidenne, T., Bannelier, C., Combes, S. and Fortun-Lamothe, L. (2009a). Interaction between the energetic feed concentration and the restriction strategy - impact on feeding behaviour, growth and health of the rabbit. In: Proceedings of the 13ème J. Rech. Cunicole. 17-18 November 2009, Le Mans, France. pp. 63-66.

Gidenne, T., Travel, A., Murr, S., Oliveira, H., Corrent, E., Foubert, C., Bebin, K., Mevel, L., Rebours, G., Renouf, B. and Gigaud, V. (2009b). Restricted intake and feed distribution 
mode - impact on feeding behavior, digestion and carcass quality. In: Proceedings of the 13ème J. Rech. Cunicole. 17-18 November 2009, Le Mans, France. pp. 43-46.

Gidenne, T., Combes, S., Feugier, A., Jehl, N., Arveux, P., Boisot, P., Briens, C., Corrent, E., Fortune, H., Montessuy, S. and Verdelhan, S. (2009c). Feed restriction strategy in the growing rabbit. 2. Impact on digestive health, growth and carcass characteristics. Animal, 3(4), pp. 509-515.

Gidenne, T., Carabaño, R., García, J. and De Blas, J.C. (2010a). Fibre digestion. In Proc. Nutrition of the Rabbit, 2nd Edition. 2010, C. de Blas and J. Wiseman (eds). CCAB International, pp. 66-82.

Gidenne, T., García, J., Lebas, F. and Licois, D. (2010b). Nutrition and feeding strategy: interactions with pathology. In Proc. Nutrition of the Rabbit, 2nd Edition. 2010, C. de Blas and J. Wiseman (eds). CCAB International, pp. 179-199.

Gidenne, T., Combes, S., Briens, C., Duperray, J., Rebours, G., Salaun, J.M., Weissman, D., Fortun-Lamothe, L., Combe, Y. and Travel, A. (2011). Restricted intake and dietary protein concentration: effect on digestion and nitrogen excretion. In Proc. 13ème J. Rech. Cunicole, 22-23 nov., Le Mans, ITAVI publ., Paris, France, pp. 21-24.

Gidenne, T., Combes, S. and Fortun-Lamothe, L. (2012). Feed intake limitation strategies for the growing rabbit: effect on feeding behaviour, welfare, performance, digestive physiology and health: a review. Animal, 6(9), pp. 1407-1419.

Gidenne, T., Combes, S. and Fortun-Lamothe, L. (2013). Replacement of protein by digestible fibre in the growing rabbit: 2 - impact on performances, digestive health and nitrogen output. Anim. Feed Sci. Technol., 183(3-4), pp. 142-150. 
Gidenne, T., Garreau, H., Drouilhet, L., Aubert, C. and Maertens, L. (2017a). Improving feed efficiency in rabbit production, a review on nutritional, technico-economical, genetic and environmental aspects. Anim. Feed Sci. Technol., 225, pp. 109-122.

Gidenne, T., Fortun Lamothe, L., Bannelier, C., Molette, C., Gilber, T.H., Chemit, M.L., Segura, M., Benitez, F., Garreau, H. and Drouilhet, L. (2017b). Direct and correlated responses to selection in two lines of rabbits selected for feed efficiency under ad libitum and restricted feeding: III. Digestion and excretion of nitrogen and minerals. J. Anim. Sci., 95(3), pp. 1301-1312.

Gilka, J. (1975). Effect of fatigue in slaughter rabbits on the quality of their meat. Vet. Med. Praha, 20(2), pp. 101-112.

Grisham, M., Reginald, G. and Garrett, R. (1999). Biochemistry. Philadelphia: Saunders College Pub, pp. 426.

Goering, H.K. and Van Soest, P.J. (1970). Forage Fibre Analyses (Apparatus, Reagents, Procedures and Someapplications). Agric. Handbook n 379. ARS, USDA, Washington, DC.

Gómez-Conde, M.S., Pérez de Rozas, A., Badiola, I., Pérez-Alba, L., De Blas, J.C., Carabaño, R. and García, J. (2009). Effect of neutral detergent soluble fibre on digestion, intestinal microbiota and performance in twenty-five day old weaned rabbits. Livest. Sci., 125(23), pp. 192-198.

Gondret, F., Mourot, J. and Bonneau, M. (1997). Developmental changes in lipogenic enzymes in muscle compared to liver and extramuscular adipose tissues in the rabbit (Oryctolagus cuniculus). Comp. Biochem. Physiol., 117(2), pp. 259-265. 
Gondret, F., Lebas, F. and Bonneau, M. (2000). Restricted feed intake during fattening reduces intramuscular lipid deposition without modifying muscle fiber characteristics in rabbits. J. Nutr., 130(2), pp. 228-233.

Gondret, F., Combes, S., Larzul, C. and de Rochambeau, H. (2002). Effect of divergent selection for body weight at a fixed age on histological, chemical and rheological characteristics of rabbit muscle. Livest. Prod. Sci., 76(1-2), pp.81-89.

Granat, J., Palanska, O., Zelnik. J., Bulla, J. and Palenik, S. (1977). The basic chemical composition of broiler rabbit meat. Zivocisna Vyroba, 22, pp. 375-382.

Gutiérrez, I., Espinosa, A., García, J., Carabaño, R. and De Blas, J.C. (2002a). Effects of starch and protein sources, heat processing, and exogenous enzymes in starter diets for early weaned rabbits. Anim. Feed Sci. Technol., 98(3), pp.175-186.

Gutiérrez, I., Espinosa, A., García, J., Carabaño, R. and De Blas, J.C. (2002b). Effect of levels of starch, fiber and lactose on digestión and growth performance of early-weaned rabbits. J. Anim. Sci., 80(4), pp. 1029-1037.

Hernández, P. and Dalle Zotte, A. (2010). Influence of diet on rabbit meat quality. In Nutrition of the Rabbit, 2nd Edition. 2010, C. de Blas and J. Wiseman (eds). CCAB International, pp. 163-178.

Hernández, P., Pla, M. and Blasco, A. (1998). Carcass characteristics and meat quality of rabbit lines selected for different objectives: II. Relationships between meat characteristics. Livest. Prod. Sci., 54(2), pp. 125-131. 
Hernández, P., Aliaga, S., Pla, M. and Blasco, A. (2004). The effect of selection for growth rate and slaughter age on carcass composition and meat quality traits in rabbits. J. Anim. Sci., 82(11), pp. 3138-3143.

Köver, G.I., Sorensen, P., Szendrö, Z.S. and Mililsits, G. (1996). In vivo measurement of perirrenal fat by magnetic tomography. In Proc. 6th World Rabbit Congress, Toulouse, France, 3, pp. 191-194.

Köver, G.I., Szendrö, Z.S., Romvari, R., Jensen, J.F., Sorensen, P. and Mililsits, G. (1998). In vivo measurement of body parts and fat deposition in rabbit by MRI. World Rabbit Sci., 6(2), pp. 1991-1994.

Knudsen, C., Combes, S., Briens, C., Coutelet, G., Duperray, J., Rebours, G., Salaun, J.M., Travel, A., Weissman, D. and Gidenne, T. (2014). Increasing the digestible energy intake under a restriction strategy improves the feed conversion ratio of the growing rabbit without negatively impacting the health status. Livest. Sci., 169, pp. 96-105.

Knudsen, C., Combes, S., Briens, C., Coutelet, G., Duperray, J., Rebours, G., Salaun, J.M., Travel, A., Weissman, D. and Giddene, T. (2017). Substituting starch with digestible fiber does not impact on health status or growth in restricted fed rabbits. Anim. Feed Sci. Technol., 226, pp. 152-161.

Krieg, R., Schüle, S. and Dohms, J. (2008). Lignocellulose als sichere Rohfaserquelle zur Leistungsstabilisierung bei Häsinnen und Jungtieren in der Kaninchenzucht. In: 7.BOKU- Symposium Tierernährung: Wien, Austria, pp. 136 - 145. 
Lambertini, L., Bergoglio, G., Masoero, G. and Gramenzi, A. (1996). Comparison between Provisal and Hyla rabbit strains. In Slaughtering performances and muscle composition. In Proc. the 6th world Rabbit Congress, Toulouse, France, 3, pp. 195-199.

Lazzaroni, C., Biagini, D. and Lussiana, C. (2009). Different rearing systems for fattening rabbits: Performance and carcass characteristics. Meat Sci., 82(2), pp. 200-204.

Lebas, F. (1975). Influence de la tener en énergie de l'aliment sur les performances de croissance chez le lapin. Ann. Zootechn., 24(2), pp. 281-288.

Lebas, F. and Ouhayoun, J. (1987). Incidence du neveau protéique de l`aliment, du milieu d'elevage et de la saison sur la croissance et les qualités bouchères du lapin. Ann Zootech., 36(4), pp. 421-432.

Ledin, I. (1984). Effect of restricted feeding and realimentation on growth, carcass composition and organ growth during the first seven days of realimentation in rabbit. Acta Agric. Scand., 34, pp. 54-66.

Liangzhan, S., Xian, J., Caixia, Z., Zhaohui, F. and Fuchang, L. (2017). Effect of substitution of oat hulls for traditional fiber source on digestion and performance of fattening rabbits. Animal, 11(6), pp. 968-974.

Lukaski, H.C., Bolonchuck, W.W., Hall, C.B. and Siders, W.A. (1985a). Validation of tretapolar bioelectrical impedance method to assess human body composition. J. Appl. Phisiol., 60(4), pp. 1327-1332.

Lukaski, H.C., Johnson, P.E., Bolonchuk, W.W. and Lykken, G.I. (1985b). Assessment of fatfree mass using bioelectric impedance measurements of the human body. Am. J. Clin. Nutr., 41(4), pp. 810-817. 
Lukefahr, S., Hohenboken, W.D., Cheeke, P.R., Patton, N.M. and Kennick, W.H. (1982). Carcass and Meat Characteristics of Flemish Giant and New Zealand White Purebred and Terminal-Cross Rabbits, J. Anim. Sci., 54(6), pp. 1169-1174.

MacDonald, L., Radler, M., Paoline, A.G. and Kent, S. (2011). Calorie restriction attenuates LPS-induced sickness behaviour and shifts hypothalamic signalling pathways to an antiinflammatory bias. Am. J. Physiol. Regul. Integr. Comp. Physiol., 301(1), pp. 172-184.

Maertens, L. (1992). Selection scheme, performance level and comparative test of two lines of meat rabbits. J. Appl. Rabbit Res., 15, pp. 206-212.

Maertens, L. (1998). Fats in rabbit nutrition: a review. World Rabbit Sci., 6(3-4), pp. 341-348

Maertens, L. (1999). Towards reduced feeding costs, dietary safety and minimal mineral excretion in rabbits: a review and opinion article. World Rabbit Sci., 7(2), pp. 65-74.

Maertens, L., Luzi, F. and De Groote, G. (1997). Effect of dietary protein and amino acids on the performance, carcass composition and $\mathrm{N}$-excretion of growing rabbits. Ann. Zootech., 46(3), pp. 255-268.

Maertens, L., Cavani, C., Luzi, F. and Capozzi, F. (1998). Influence du rapport proteins/énergie et de la source énergétique de l'aliment sur les performances, l’excrétion azotée et les caractéristiques de la viande des lapins en finition. 7emes journ. Rech. Cunicole. Lyon. France. Ed. INRA-IRTAVI, pp. 163-166.

Maertens, L., Pérez, J. M., Villamide, M., Cervera, C., Gidenne, T. and Xiccato, G. (2002). Nutritive value of raw materials for rabbits: EGRAN tables 2002. World Rabbit Sci., 10(4), pp. 157-166 
Maertens, L., Cavani, C. and Petracci, M. (2005). Nitrogen and phosphorus excretion on commercial rabbit farms: calculations based on the input-output balance. World Rabbit Sci. 13(1), pp. 3-16.

Makled, M.N., Metwally, M.A., Soliman, I.A. and Younis, H.A. (2005). Impact of different levels of dietary multienzymes supplement on California rabbit performance. In Proc.: 3rd Int. Poult. Conf., Hurghada, Egypt.

Marchello, M.J. and Slanger, W.D. (1992). Use of bioelectrical impedance to predict leanness of Boston butts. J. Anim. Sci., 70, pp. 3443-3450.

Marchello, M.J. and Slanger, W.D. (1994). Bioelectrical Impedance can predict skeletal muscle and fat-free skeletal muscle of beef cows and their carcass. J. Anim. Sci., 72(12), pp. 3118-3123.

Marchello, M.J., Slanger, W.D. and Carlson, J.K. (1999). Bioelectrical Impedance: fat content of beef and pork from different size grinds. J. Anim. Sci., 77(9), pp. 2464-2468.

Margüenda, I., Carabaño, R., García-Rebollar, P., De Blas, J.C. and García-Ruiz, A.I. (2006). Effect of the substitution of starch sources or wheat straw with apple pulp on growth performance, mortality and carcass yield, under field conditions. In Proc. $3 r d$ Congreso de Cunicultura de las Américas, Maringá, Brasil, 44, pp. 1-6.

Margüenda, I., Nicodemus, N., García-Rebollar, P., Villarroel, M., Sevilla, L., Vadillo, S. and Carabaño, R. (2008). Efecto del tiempo de ayuno sobre el rendimiento y la calidad microbiológica de la canal del conejo. In Proc. XXXIII Symposyum de ASESCU. Calahorra, España, pp 24-27. 
Margüenda, I., Nicodemus, N., García-Rebollar, P., Romero, C., Sevilla, L., Vadillo, S. and Carabaño, R. (2009). Efecto del nivel y tipo de fibra y del tiempo de ayuno sobre el rendimiento y la calidad microbiológica de la canal del conejo. In Proc. XXXIV Symposyum de ASESCU. Sevilla, España, pp 115-120.

Margüenda, I., Nicodemus, N., Vadillo, S., Sevilla, L., García-Rebollar, P., Villarroel, M., Romero, C. and Carabaño, R. (2012). Effect of dietary type and level of fibre on rabbit carcass yield and its microbiological characteristics. Livest. Sci., 145(1-3), pp. 7-12.

Martínez, P. and Fernández Carmona, J. (1981). Efecto de la temperatura ambiente sobre el engorde del conejo. In Proc. Departamento Zootecnia. Universidad Politécnica, Valencia. 14, pp. 23-25.

Martínez-Vallespín, B., Martínez-Paredes, E., Ródenas, Cervera, C., Pascual, J.J. and Blas, E. (2011). Combined feeding of rabbit female and young: Partial replacement of starch with acid detergent fibre or/and neutral detergent soluble fibre at two protein levels. Livest. Sci., 141(2-3), pp. 155-165.

Martínez-Vallespín, B., Martínez-Paredes, E., Ródenas, L., Moya, V.J., Cervera, C., Pascual, J.J. and Blas, E. (2013). Partial replacement of starch with acid detergent fibre and/or neutral detergent soluble fibre at two protein levels: Effects on ileal apparent digestibility and caecal environment of growing rabbits. Livest. Sci., 154(1-3), pp. 123-130.

Marounek, M., Vovk, S. and Skrivanová, V. (1995). Distribution of activity of hydrolytic enzymes in the digestive tract of rabbits. Br. J. Nutr., 73(3), pp. 463-469. 
Masoero, G., Riccioni, L., Bergoglio, G. and Napoletano, F. (1992). Implications of fasting and of transportation for a high-quality rabbit meat product. J. Appl. Rabbit Res., 15, pp. 841-847.

Mazzone, G., Vignola, G., Giammarco, M., Manetta, A.C. and Lambertini, L. (2010). Effects of loading methods on rabbit welfare and meat quality. Meat Sci., 85(1), pp. 33-39.

Metzger, Sz., Kustos, K., Szendrö, Zs., Szabó, A., Eiben, Cs. and Nagy, I. (2003). The effect of housing system on carcass traits and meat quality of rabbit. World Rabbit Sci., 11(1), pp. 1-11.

Metzger, Sz., Odermatt, M., Szendro, Zs., Mohaupt, M., Romvári, R., Makai, A., BiróNémeth, E., Sipos, L., Radnai, I. and Horn, P. (2006). A study of the carcass traits of different rabbit genotypes. World Rabbit Sci., 14(2), pp. 107-114.

Motta Ferreira, W., Fraga, M.J. and Carabaño, R. (1996). Inclusion of grape pomace, in substitution for Lucerne hay, in diets for growing rabbits. Anim. Sci., 63(1), pp. 167174.

Naveed, A., Acamovic, T. and Bedford, M.R. (1998). Effect of enzyme supplementation of UK-grown Lupinus albus on growth performance in broiler chickens. Br. Poult. Sci. 39, pp. S36-S37.

Nicodemus, N., Carabaño, R., García, J., Méndez, J. and De Blas, J.C., (1999). Performance response of lactating and growing rabbits to dietary lignin content. Anim. Feed. Sci. Technol., 80(1), pp. 43-54.

Nicodemus, N., García, J., Carabaño, R. and De Blas, C. (2006). Effect of a reduction of dietary particle size by substituting a mixture of fibrous by-products for lucerne hay on 
performance and digestion of growing rabbits and lactating does. Livest. Sci., 100(2), pp. $242-250$.

Nicodemus, N., García, J., Carabaño, R. and De Blas, J.C. (2007). Effect of substitution of a soybean hull and grape seed meal mixture for traditional fiber sources on digestion and performance of growing rabbits and lactating does. J. Anim. Sci., 85(1), pp. 181-187

Nicodemus, N., Pereda, N., Romero, C. and García-Rebollar, P. (2009). Évaluation de la tecnique d'impedance bioélectrique (IBE) pour estimer la composition corporelle de lapines reproductives. Procedures 13èmes J. Rech. Cunicole, pp. 109-112.

Oloruntola, O., Agbede, J., Onibi, G.E., Igbasan, F.A., Ogunsipe, M.H. and Ayodele, S.O. (2018). Rabbits fed fermented cassava starch residue II: Enzyme supplementation influence on performance and health status. Archiv. Zootec., 67, pp. 588-595.

Olukosi, O.A., Cowieson, A.J. and Adeola, O. (2007). Age-related influence of a cocktail of xylanase, amylase, and protease or phytase individually or in combination in broilers. Poult. Sci., 86(1), pp. 77-86.

Ouhayoun, J. (1980). Comparative development of the body components of three genetic types of rabbits during postnatal growth. Reprod. Nutr. Dev., 20(4), pp. 949-959.

Ouhayoun, J. (1984). Croissance et qualities bouchères du lapin. Cuni. Sciences, 11(4), pp.181188.

Ouhayoun, J. (1989). La composition corporelle du lapin. Facteurs de variations. INRA Pros. Anim., 2(3), pp. 215-226.

Ouhayoun, J. (1991a). La calidad de la carne de conejo. Conferencia Zootech., Módena. Italia. Boletín de Cunicultura, 55, pp. 31-36. 
Ouhayoun, J. (1991b). Sacrificio y calidad de la carne de conejo. Cunicultura, 16, pp. 13-21.

Ouhayoun, J. (1998). Influence of the diet on rabbit meat quality. The nutrition of the rabbit. De Blas, C. and Wiseman, J., (eds.). CAB International, Wallingford, UK, pp. 177-195.

Ouhayoun, J. and Cheriet, S. (1983). Valorization compare d'aliments à niveaux protéiques différents, par des lapins sélectionnés sur la vitesse de croissance et par des lapins provenant d’élevages traditionnels. I. Étude des performances de croissance et de la composition du gain de poids. Ann. Zootech., 32(3), pp. 257-276.

Ouhayoun, J., Rouvier, R., and Poujardieu, B. (1974). Relation gènetiques entre les performances de croissance ponderale et le mètabolisme du tissu musculaire du lapin. In Proc. 1er Congrès Mondial de Gènétique Appliquée à l’Elevage. Madrid.

Ouhayoun, J., Gidenne, T. and Demarne, Y. (1985). Evolution post-natal de la composition en acides gras des lipides du tissu adipeux et du tissu musculaire chez le lapin en régime hypolipidique. Reprod. Nutr. Dev., 25(3), pp. 505-519.

Paci, G., Preziuso, G., D’Agata, M., Russo, C. and Dalle Zotte, A. (2013). Effect of stocking density and group size on growth performance, carcass traits and meat quality of outdoor-reared rabbits. Meat Sci., 93(2), pp. 162-166.

Pálsson, H. (1955). Conformation and body composition. In: Hammond, J. (Ed.), Progress in the Physiology of Farm Animals II. Butterworth Publications Ltd, London, UK, pp. 430542.

Pascual, M. and Pla, M. (2007). Changes in carcass composition and meat quality when selecting rabbits for growth rate. Meat Sci., 77(4), pp. 474-481. 
Parigi Bini, R., Xiccato, G., Cinetto, M. and Dalle, A. (1992). Effect of slaughter age and weight on carcass and meat quality of the commercial rabbit. J. Appl. Rabbit Res., 15, pp. $819-826$.

Parigi Bini, R., Xiccato, G., Dalle Zotte, A and Carazzolo, A. (1994). Effets de differents niveaux de fibre alimetaire sur l’utilisation digestive et al qualité bouchère chez le lapin. Proc. 6emes J. Rech. Cunicole. 6-7 December, La Rochelle, France, ITAVI, Paris. 2, pp. 347-354.

Partridge, G.G., Findlay, M. and Fordyce, R.A. (1986). Fat supplementation of diets for growing rabbits. Anim. Feed Sci. Technol., 16(1-2), pp.109-117.

Partridge, G.G., Garthwaite, P.H. and Findlay, M. (1989). Protein and energy retention by growing rabbits offered diets with increasing proportion of fibre. J. Agric. Sci. UK., 112(2), pp. 171-178.

Pereda, N. (2010). Evaluación de la técnica del Análisis de Impedancia Bioeléctrica para predecir la composición corporal: aplicación en conejas sometidas a diferentes sistemas de alimentación durante la recría. PhD Thesis. Polytechnic University of Madrid, Madrid, Spain.

Pérez, E. (1978). Crecimiento de conejos en el periodo destete-venta. PhD Thesis. Polytechnic University of Madrid, Madrid, Spain.

Pérez, J.M., Gidenne, T., Lebas, F., Caudron, Y., Arveux, P., Bourdillon, A., Duperray, J. and Messager, B. (1994). Apports de lignines et alimentation du lapin en croissance. 2. Consequences sur les performances et la mortalite. Ann. Zootech., 43(4), pp. 323-332. 
Pérez, J.M., Lebas; F. and Gidenne, T. (1995). European reference method for in vivo determination of diet digestibility in rabbits. World Rabbit Sci.. 3(1), pp. 41-43.

Pérez, J.M., Gidenne, T., Bouvarel, I., Caudron, I., Arveux, P., Bourdillon, A., Briens, C., Le Naour, J., Messager, B. and Mirabito, L. (1996). Apports de cellulose dans l'alimentation du lapin en croissance. II. Conséquences sur les performances et la mortalité. Ann. Zootech., 45(4), pp. 299-309.

Petracci, M., Verardo, V. and Cavani, C. (2012). Nuevas tendencias en el procesado de la carne de conejo. In Proc. XXXVIII Symposium de Cunicultura de ASESCU, pp. 12-21.

Piles, M., Blasco, A. and Pla, M. (2000). The effect of selection for growth rate on carcass composition and meat characteristic of rabbits. Meat Sci., 54(4), pp. 347-355.

Pla, M. (1996). Carcass composition and meat quality of rabbits selected from different criteria. In Proc. 6th World Rabbit Congress, Toulouse, 2, pp. 347-350.

Pla, M., Hernández, P. and Blasco, A. (1996). Carcass composition and meat characteristics of two rabbit breeds of different degrees of maturity. Meat Sci., 44(1-2), pp. 85-92.

Price, J.F. and Schweigert, B.S. (1976). Ciencia de la Carne y de los productos cárnicos. Ed. Acribia. Zaragoza.

Raimondi, R., De Maria, C., Auxilía, M.T. and Masoero, G. (1974). Effetto comparativo di diete a diverso contenuto energético e proteico sulle caratteristiche chimico bromatologiche delle carni di coniglio. Ann. 1st. Sper. Zootec., 7, pp. 45-61.

Rao, D.R., Chen, C., Sunci, G.R. and Johnson, W.M. (1978). Effect of weaning and slaughter ages on rabbit meat production. II Carcass quality and composition. J. Anim. Sci., 46(3), pp. 578-583. 
Real Decreto 1528/2012, de 8 de noviembre de 2012, por el que se establecen las normas aplicables a los subproductos animales y los productos derivados no destinados al consumo humano. Boletín Oficial del Estado No 277, pp. 80199-80226.

Rebollar, P.G., Pereda, N., Schwarz, B.F., Millán, P., Lorenzo, P.L. and Nicodemus, N. (2011). Effect of feed restriction or feeding high-fibre diet during the rearing period on body composition, serum, parameters and productive performance of rabbit does. Anim. Feed Sci. Technol., 163(1), pp. 67-76.

Reglamento (CE) No 1069/2009 del Parlamento Europeo y del Consejo, de 21 de octubre de 2009, por el que se establecen las normas sanitarias aplicables a los subproductos animales y los productos derivados no destinados al consumo humano. Diario Oficial de la Unión Europea, pp. L 300/1-L 300/33.

Regulation (EU) No 1169/2011 of the European Parliament and of the Council of 25 October 2011 on the provision of food information to consumers, amending Regulations (EC) No 1924/2006 and (EC) No 1925/2006 of the European Parliament and of the Council, and repealing Commission Directive 87/250/EEC, Council Directive 90/496/EEC, Commission Directive 1999/10/EC, Directive 2000/13/EC of the European Parliament and of the Council, Commission Directives 2002/67/EC and 2008/5/EC and Commission Regulation (EC) No 608/2004. Official Journal of the European Union L304/18.

Richmond, R.J. and Berg, R.T. (1971). Tissue development in swine as influenced by liveweight, breed, sex and ration. Can. J. of Anim. Sci., 51(1), pp.31-39. 
Rojas Méndez, M.P. (2011). Uso estratégico de enzimas en nutrición animal. Available at: http://www.ameveaecuador.org/memorias2011/pdf/USO\%20ESTRATEGICO\%20DE\%20ENZIMAS\%20 EN\%20NUTRICION\%20ANIMAL.pdf

Romero, C., Cuesta, S., Astillero, J.R., Nicodemus, N. and De Blas, C. (2010). Effect of early feed restriction on performance and health status in growing rabbits slaughtered at $2 \mathrm{~kg}$ live weight. World Rabbit Sci. 18(4), pp. 211-218.

Romero, C., Nicodemus, N., Rodríguez, J.D., García A.I. and De Blas, J.C. (2011). Effect of type of grinding of barley and dehydrated alfalfa on performance, digestion, and crude mucin ileal concentration in growing rabbits. J. Anim. Sci., 89(8), pp. 2472-2484.

Rymkiewicz, J. and Lewczuk, A. (1999). A comparison of the body weight and slaughter value of Danish White and New Zealand White rabbits. Przeglad Hodowlany, 4, pp. 26-28.

Sahraei, M. (2012). Feed restriction in broiler chickens production: a review. Glob. Vet., 8, pp. 449-458.

Saiz, A, (2016). Validation and application of bioelectrical impedance (BIA) method to determine body and carcass composition and nutrient retention of growing rabbits. $\mathrm{PhD}$ Thesis. Polytechnic University of Madrid, Madrid, Spain.

Saiz, A., García-Ruiz, A.I., Fuentes-Pila, J. and Nicodemus, N. (2017). Application of bioelectrical impedance analysis to assess rabbit's body composition from 25 to $77 \mathrm{~d}$ of age. J. Anim. Sci., 95(6), pp. 2782-2793.

Santomá, G., De Blas, J.C., Carabaño, R.M. and Fraga, M.J. (1987). The effects of different fats and their inclusion level in diets for growing rabbits. Anim. Prod., 45(2): 291-300. 
SAS Institute. 2002. SAS/STAT® User's Guide (Release 8.2). SAS Inst. Inc., Cary C, USA.

Schanbacher, B.D., Hahn, G.L. and Neinaber, J.A. (1982). Effects of contrasting photoperiods and temperatures on performance traits of confinement-reared ewe lambs. J. Anim. Sci., 55(3), pp. 620-626.

Schlolaut, W., Lange, K. and Schlüter, H. (1978). Der Einfluss der Fütterungsintensität auf die Mastleistung und die Schlachtkörperqualität beim Jungmastkaninchen. Züchtungskunde, 50, pp. 401-411.

Sequeira, J., Nicodemus, N., Carabaño, R. and Villamide, M.J. (2000). Effect of type of wheat and addition of enzymes on some digestive parameters at different sampling time. In Proc. 7th World Rabbit Congress. Valencia, Spain, pp. 437-444.

Shanmuganathan, T., Samarasinghe, K., and Wenk, C. (2004). Supplemental enzymes, yeast culture and effective micro-organism cuture to enhance the performance of rabbits fed diets containing high levels of rice bran. Asian-Aust. J. Anim. Sci., 17(5), pp. 678-683.

Spanish Royal Decree 53/2013, de 1 de febrero, por el que se establecen las normas básicas aplicables para la protección de los animales utilizados en experimentación y otros fines científicos, incluyendo la docencia, 2013. Boletín Oficial del Estado N.o 34, 1137011421.

Such, X. (1981). Caracterización de la canal y calidad de la carne de conejo consumido en España. In Proc: VI Symposium de Cunicultura. 3 y 4 de diciembre.

Sunki, G.R., Annapureddy, R. and Rao, D.R. (1978). Microbial, biochemical and organoleptic changes in ground rabbit meat stored at 5 to $7^{\circ}$ C. J. Anim. Sci., 46 (3), pp. 584-588 
Swantek, P.M., Crenshaw, J.D., Marchello, M.J. and Lukaski, H.C. (1992). Bioelectrical impedance: a non-destructive method to determine fat-free mass of live market swine and pork carcasses. J. Anim. Sci., 70(1), pp. 169-177.

Swantek, P.M., Marchello, M.J., Tilton, J.E. and Crenshaw, J.D. (1999). Prediction of fat-free mass pigs from 50 to 130 kilograms live weight. J. Anim. Sci., 77(4), pp. 893-897.

Szendrö, Zs. and Kustos, K. (1992). The effect of starvation on the carcass yield of New Zealand white rabbits. J. Appl. Anim. Res., 15, pp. 879-883.

Szendrö, Z.S., Horn, P., Köver, G.I., Berényl, E., Radnai, I. and Biro-Nemeth, E. (1992). In vivo measurement of the carcass traits of meat type rabbits by X-ray computerised tomography. J. Appl. Rabbit Res., 15, pp. 799-809.

Taboada, E., Mendez, J. and De Blas, J.C. (1996). The response of highly productive rabbits to dietary sulphur amino acid content for reproduction and growth. Reprod. Nutr. Dev., 16, pp. 191-203.

Tazzoli, M., Trocino, A., Birolo, M., Radaelli, G. and Xiccato, G. (2015). Optimizing feed efficiency and nitrogen excretion in growing rabbits by increasing dietary energy with high-starch, high-soluble fibre, low-insoluble fibre supply at low protein levels. Livest. Sci., 172, pp. 59-68.

Trocino, A., Xiccato, G., Sartori, A. and Queaque, P.I. (2000). Feeding plans at different protein levels: effects on growth performance, meat quality and nitrogen excretion in rabbits. Proc. 7th World Rabbit Congress, Vol. C, pp. 467-474.

Trocino, A., Xiccato, G., Queaque, P.I. and Sartori, A. (2003). Effect of transport duration and gender on rabbit carcass and meat quality. World Rabbit Sci., 11(1), pp. 23-32. 
Trocino, A., Fragkiadakis, M., Majolini, D., Carabaño, R. and Xiccato, G. (2011). Effect of the increase of dietary starch and soluble fibre on digestive efficiency and growth performance of meat rabbits. Anim. Feed Sci. and Technol., 165(3-4), pp. 265-277.

Trocino, A., García, J., Carabaño, R. and Xiccato, G. (2013). A meta-analysis on the role of soluble fibre in diets for growing rabbits. World Rabbit Sci., 21(1), pp.1-5.

Tucker, H.A., Petitclerec, D. and Zinn, S.A. (1984). The influence of photoperiod on body weight gain, body composition, nutrient intake, and hormone secretion. J. Anim. Sci., 59(6), pp. 1610-1620.

Tumová, E., Skrivanova, V. and Skrivan, M. (2003). Effect of restricted feeding time and quantitative restriction in growing rabbits. Arch. Geflugelkd. 67, pp. 182-190.

Tumová, E., Zita, L. and Stolc, L. (2006). Carcass quality in restricted and ad libitum fed rabbits. Czech J. Anim. Sci., 51(5), pp. 214-219.

Tumová, E., Zita, L., Skrivanová, V., Fuciková, A., Skrivan, M. and Burešová, M. (2007). Digestibility of nutrients, organ development and blood picture in restricted and ad libitum fed broiler rabbits. Arch. Geflugelkd. 71, pp. 6-12.

Tumova, E., Volek, Z., Chodova, D., Hartlova, H., Makovicky, P., Svobodova, J., Ebeid, T.A. and Uhlirova, L. (2016). The effect of 1-week feed restriction on performance, digestibility of nutrients and digestive system development in the growing rabbit. Animal, 10(1), pp. 1-9.

Van Soest, P.J., Robertson, J.B. and Lewis, B.A. (1991). Methods for dietary fiber, neutral detergent fiber, and nonstarch polysaccharides in relation to animal nutrition. J. Dairy Sci., 74(10), pp.3583-3597. 
Van Soest, P.J. (1994). Nutritional ecology of the ruminant. 2nd Edition. Cornell University Press. Ithaca, NY.

Villalobos, O., Guillén, O. and García, J. (2008). Effect of cage density on growth and carcass performance of fattening rabbits under tropical heat stress conditions. World Rabbit Sci., 16(2), pp. 89-97.

Villena, P., García-Rebollar, P., Rebollar, P.G., Núñez, N., Nicodemus, N., Margüenda, I., and Carabaño, R. (2008). Effect of a high fibrous diet in the finishing period on carcass yield and meat quality of rabbits. In Proc. 9th World Rabbit Congress. Verona, Italy, pp. 14611465.

Whetten, R. and Sederoff, R. (1995). Lignin Biosynthesis. Plant Cell., 7(7), pp.1001-1013.

Wu, Z., Zhou, H., Li, F., Zhang, N. and Zhu, Y. (2019). Effect of dietary fiber levels on bacterial composition with age in the cecum of meat rabbits. MicrobiologyOpen, 8(5), e00708.

Xiccato, G. (1999). Feeding and meat quality in rabbits: a review. World Rabbit Sci., 7(2), pp. 75-86.

Xiccato, G., Cinetto, M. and Dalle Zotte, A. (1992). Effect of feeding plane and category of rabbit on digestive efficiency and nitrogen balance. Zootec. Nutr. Anim., 181, pp. 35-43.

Xiccato, G., Cinetto, M. and Dalle Zotte, A. (1993). Influenza del piano alimentare e dell’età di macellazione sulle prestzioni e sulla qualità della carcassa di coniglio. In Proc. $X$ Congesso ASPA, , Bologna, Italy, pp. 571-577.

Xiccato, G., Cossu, M.E., Torcino, A. and Queaque, P.I. (1998). Influene du rapport amidon/fibre et de l'addition de graisse en post-sevrage sur la digestión, les 203 
performances zootechniques et la qualité bouchère du lapin. Proc. 7 J. Rech. Cunicole, , Lyon, France, pp. 159-162.

Xiccato, G., Verga, M., Trocino, A., Ferrante, V., Queaque, P.I. and Sartori, A. (1999). Influence de l'effectif et de la densité par cage sur les performances productives, la qualité bouchere et le comportement chez le lapin. In Proc. 8èmes J. Rech. Cunicole, Paris, France, pp. 59-62.

Xiccato, G. and Trocino, A. (2010). Energy and protein metabolism and requirements. In Nutrition of the Rabbit. 2nd Edition. C. de Blas and J. Wiseman (eds). CAB International, pp. 83-118.

Xiccato, G., Schiavon, S., Gallo, L., Bailoni, L. and Bittante, G. (2005). Nitrogen excretion in dairy cow, beef and veal cattle pig, and rabbit farms in Northern Italy. Ital. J. Anim. Sci., 4(3s), pp. 103-111. 